\title{
Five-Year NRHP Re-Evaluation of Historic Building Assessment
}

\section{LLNL Main Site and Site $\mathbf{3 0 0}$}

W.5. Bepartapent of Energy

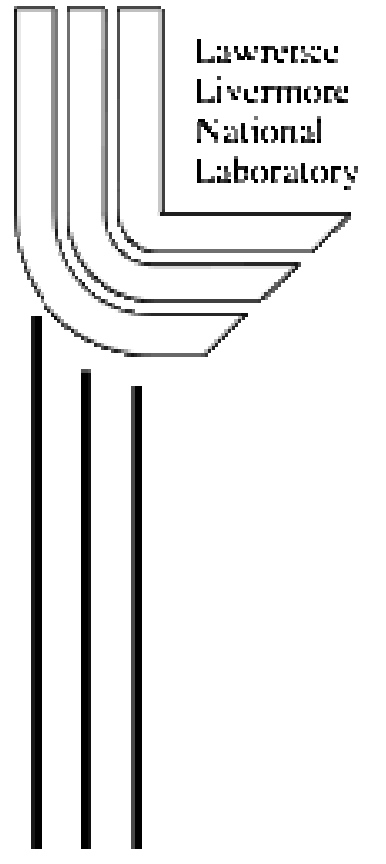

R.A. Ullrich

K.R. Heidecker

November 2011 
This document was prepared as an account of work sponsored by an agency of the United States government. Neither the United States government nor Lawrence Livermore National Security, LLC, nor any of their employees makes any warranty, expressed or implied, or assumes any legal liability or responsibility for the accuracy, completeness, or usefulness of any information, apparatus, product, or process disclosed, or represents that its use would not infringe privately owned rights. Reference herein to any specific commercial product, process, or service by trade name, trademark, manufacturer, or otherwise does not necessarily constitute or imply its endorsement, recommendation, or favoring by the United States government or Lawrence Livermore National Security, LLC. The views and opinions of authors expressed herein do not necessarily state or reflect those of the United States government or Lawrence Livermore National Security, LLC, and shall not be used for advertising or product endorsement purposes.

This work performed under the auspices of the U.S. Department of Energy by Lawrence Livermore National Laboratory under Contract DE-AC52-07NA27344. 


\section{CONTENTS}

$1.0 \quad$ Executive Summary.........................................................................................................1

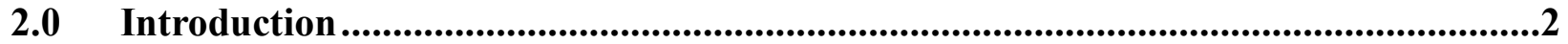

$2.1 \quad$ Purpose

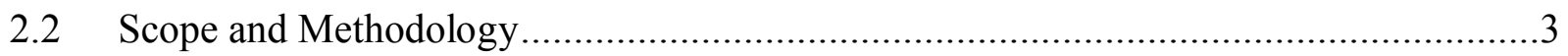

3.0 Changes in the Laboratory and Its Built Environment ..................................................3

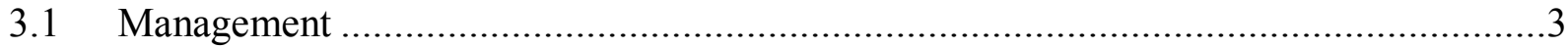

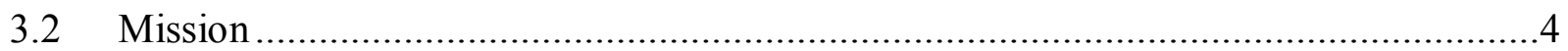

3.3 Current Emphases in Research Areas ....................................................................

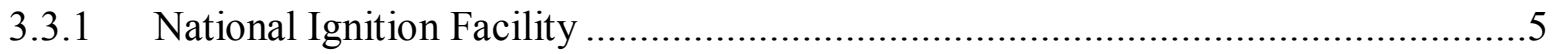

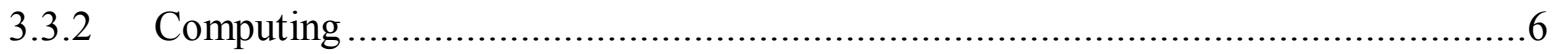

3.3.3 Homeland Security....................................................................................

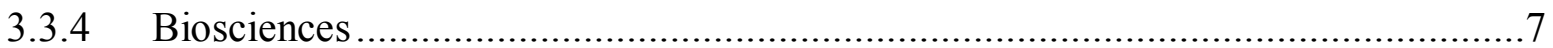

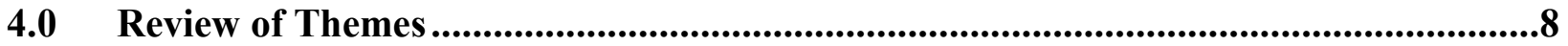

4.1 Local History and World War II..........................................................................

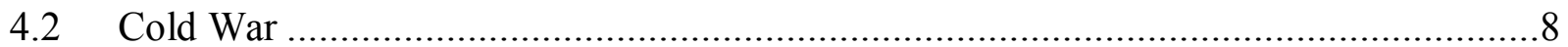

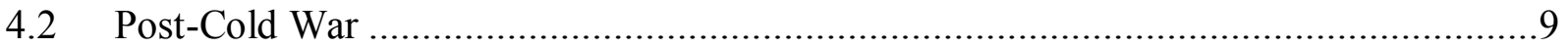

5.0 Review of Built Environment .............................................................................................10

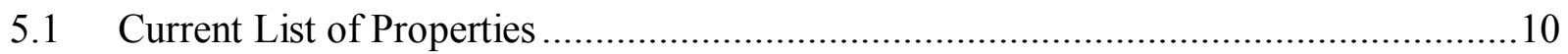

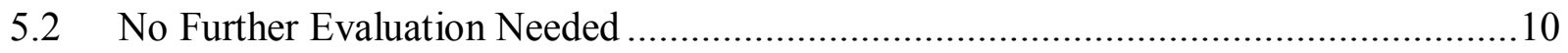

5.3 Technical Facilities Reaching 50 since 2005 Review.................................................14

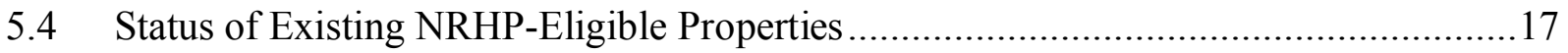

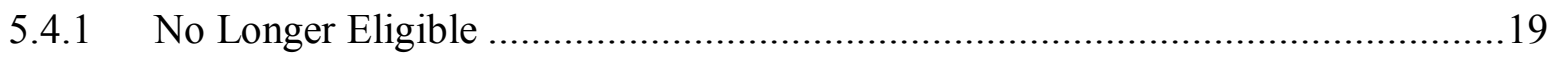

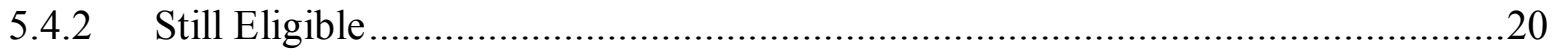

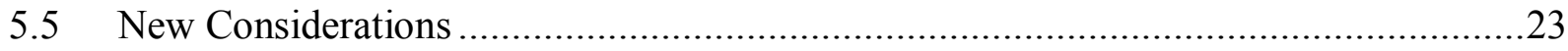

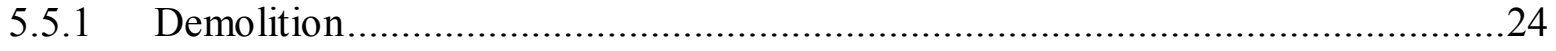

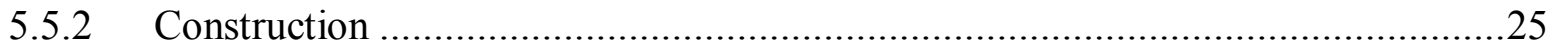

5.5.3 Reconsideration of Three Buildings from 2005 Report.......................................34 


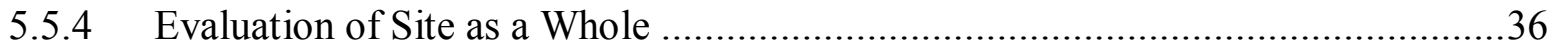

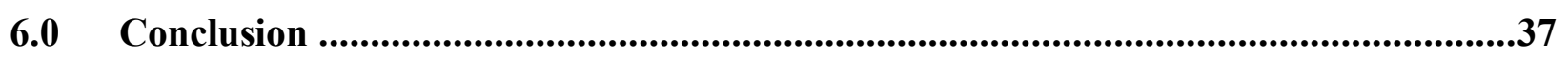

6.1 Summary of Recommendations from Re-Evaluation ..................................................

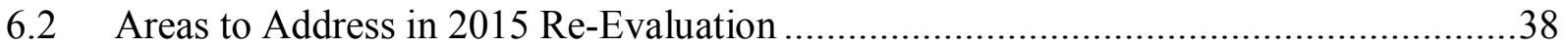

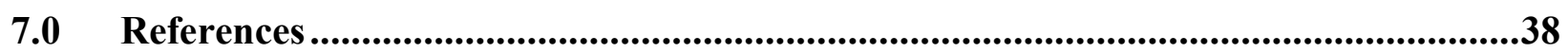

Description ...................................................................................................................1

Mission History ……........................................................................................................................

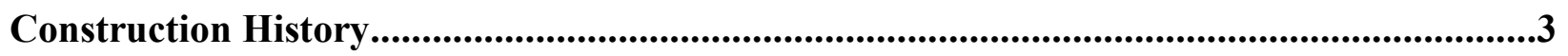

Integrity

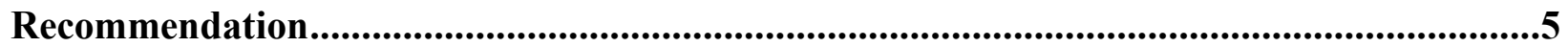

\section{FIGURES}

Figure 1. Entrance site to U-119, telecommunications facility, 2010......................................16

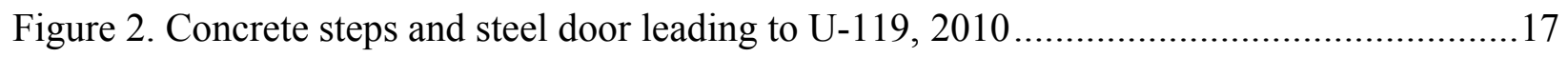

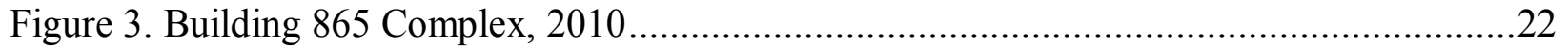

Figure 4. Landscaping of hillside and immediate area around Building 850, 2010 ...................23

Figure 5. Empty fenced lot where the drill hall portion of Building 212 once stood, 2010 ........24

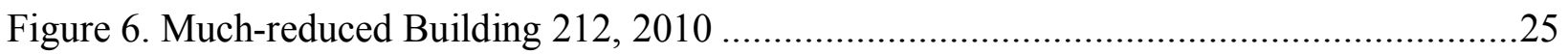

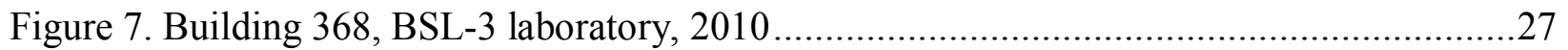

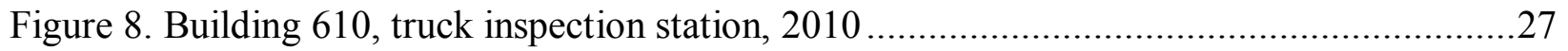

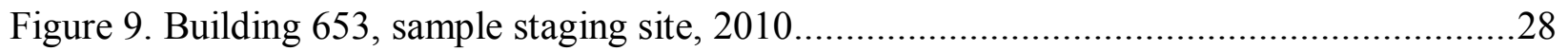

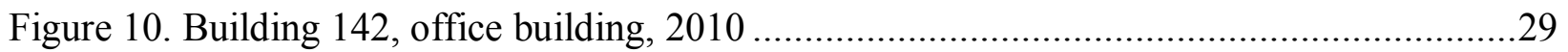

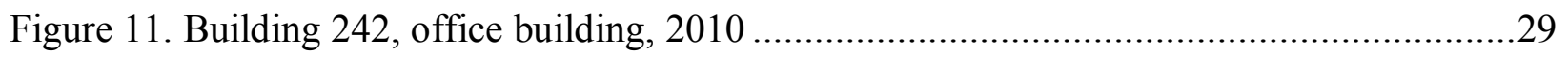

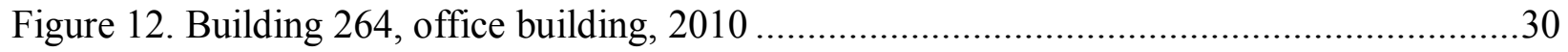

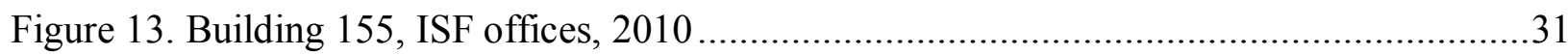

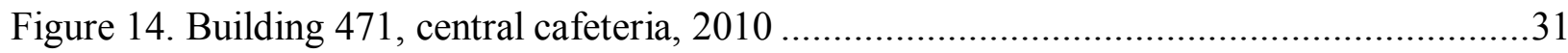

Figure 15. Building 453, Terascale Simulation Facility, south side, 2010 .................................32

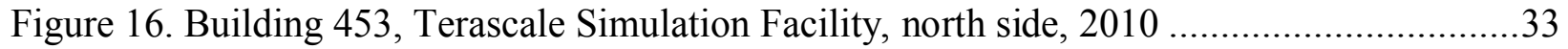

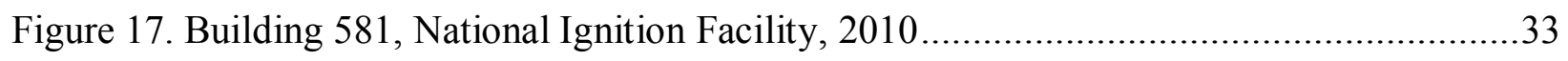

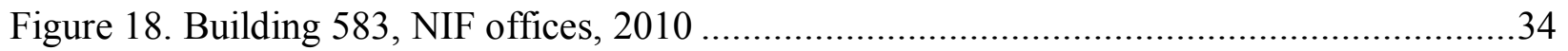

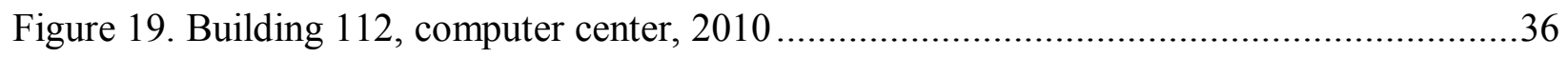

Figure 20. Building 810A, south (front) and east sides, showing both structures, $2010 \ldots \ldots \ldots \ldots \ldots . .2$

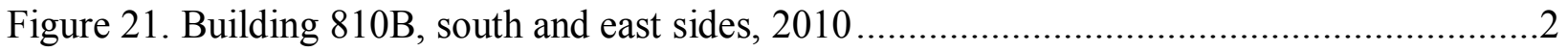




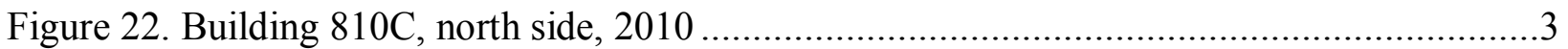

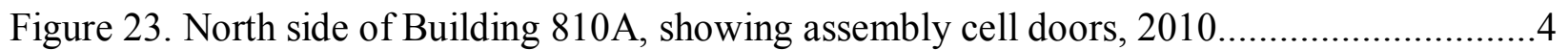

\section{TABLES}

Table 1: Properties Included in 2010 Re-Evaluation .........................................................12

Table 2. LLNL Technical Facilities Reaching 50 since 2005 Report.....................................14

Table 3. Properties Recommended for NRHP Eligibility in 2005 Report.................................18

Table 4. Current Status of Properties Considered NRHP-Eligible in 2005 Report......................19

Table 5. LLNL Buildings Constructed, 2003-2010 ..............................................................25

\section{APPENDICES}

Appendix I: List of All Buildings and Structures at LLNL Main Site and Site 300

Appendix II: LLNL Properties Turning 50 since 2005 Report

Appendix III: Site 300810 Complex Assessment

Appendix IV: Acronyms 


\subsection{EXECUTIVE SUMMARY}

The Lawrence Livermore National Laboratory (LLNL) "Draft Programmatic Agreement among the Department of Energy and the California State Historic Preservation Officer Regarding Operation of Lawrence Livermore National Laboratory" requires a review and re-evaluation of the eligibility of laboratory properties for the National Register of Historic Places (NRHP) every five years. The original evaluation was published in 2005; this report serves as the first five-year re-evaluation.

This re-evaluation includes consideration of changes within LLNL to management, to mission, and to the built environment. It also determines the status of those buildings, objects, and districts that were recommended as NRHP-eligible in the 2005 report. Buildings that were omitted from the earlier building list, those that have reached 50 years of age since the original assessment, and new buildings are also addressed in the reevaluation.

Final recommendations from this re-evaluation are:

- No buildings need to be added to the list of individual buildings eligible for the NRHP;

- Building 810 A should be added to the Site 300 Process Area and Chemistry Area Historic District;

- Buildings $810 \mathrm{~B}$ and Building $810 \mathrm{C}$ should not be included in the Site 300 Process Area and Chemistry Area Historic District, due to their age and lack of contribution to the early decades of explosive processing operations;

- Building 865 Complex, including Buildings 865A, B, D, E, G, and H, not just Building $865 \mathrm{~A}$, should be considered eligible;

- Building 332, which was determined by LSO in consultation with the California State Historic Preservation Officer (SHPO) to be NRHP eligible, has been preserved via recordation, should be allowed to evolve as needed to meet LLNL's scientific mission requirements and not be considered NRHP-eligible any longer;

- Building 391, which was determined by U.S. Department of Energy/National Nuclear Security Administration/Livermore Site Office in consultation with the California SHPO to be NRHP eligible, has been preserved via recordation, has evolved significantly, and should no longer be considered NRHP-eligible for NOVA and the laser work that preceded it; and 
- Non-Weapons Computing and Anti-Terror Research should be added to the list of themes within the Non-Weapons Research category of the Post-Cold War context.

- The 2015 five-year re-assessment should

O re-evaluate the eligibility of the main site and Site 300 for the NRHP as historic districts,

○ consider any major breakthroughs and any historical recognition of past events or people,

O address the current status of buildings and districts previously found NRHP eligible,

O begin development of the post-Cold War context and provide a deeper understanding of relevant themes for LLNL within the post-1990 period, and

○ begin assessing post-1990 buildings for exceptional significance, as the youngest of them will be 25 years old.

\subsection{INTRODUCTION}

\subsection{Purpose}

In 2004, Michael Anne Sullivan and Rebecca Ann Ullrich completed a final draft of Historic Context and Building Assessments for the Lawrence Livermore National Laboratory Built Environment (2005 Report). The text was initially published in 2005 and republished in 2007 after minor revisions. ${ }^{1}$ Lawrence Livermore National Laboratory (LLNL) and the U.S. Department of Energy/National Nuclear Security Administration/Livermore Site Office (DOE/NNSA/LSO) created a "Draft Programmatic Agreement Among the Department of Energy and the California State Historic Preservation Officer Regarding Operation of Lawrence Livermore National Laboratory" (Draft PA) that articulated the management of sites determined historic and the ongoing assessment activities required. ${ }^{2}$

\footnotetext{
${ }^{1}$ Michael Anne Sullivan and Rebecca Ann Ullrich, Historic Context and Building Assessments for the Lawrence Livermore National Laboratory Built Environment, UCRL-TR-234717 (Livermore, California: Lawrence Livermore National Laboratory, 2007).

${ }^{2}$ Kelly Heidecker and Paul McGuff, "Draft Programmatic Agreement among the Department of Energy and the California State Historic Preservation Officer Regarding Operation of Lawrence Livermore National Laboratory" (Livermore, California: LLNL, June 2011).
} 
The Draft PA requires a review and re-evaluation of the eligibility of laboratory properties for the National Register of Historic Places (NRHP) every five years. The original evaluation was published in 2005; this report serves as the first five-year reevaluation. Its purpose is to validate and provide any necessary corrections to or extensions of the 2005 report.

\subsection{Scope and Methodology}

Addressing both the main site in Livermore and LLNL's Site 300 on Corral Hollow Road in the Tracy foothills, San Joaquin and Alameda counties, this re-evaluation involved a review of the 2005 report and determination of the current status of the properties it recommended as eligible for the NRHP. The building list from 2003 (when research began) used in the 2005 report was compared to the current building list and discrepancies addressed.

A site visit allowed for consideration of changes to the LLNL built environment, including modifications to older facilities and new construction. Properties not previously addressed were evaluated. Those facilities that turned 50 years old after 2003 were reviewed. Finally, research in the online LLNL news site Newsline and archival research produced further information regarding changes to mission programs within LLNL.

Michael Anthony, LLNL staff photographer, took additional digital photographs of new buildings, buildings with modifications, and those that were omitted from the 2005 report. Mr. Anthony took all photographs for this re-evaluation and those used as figures in this report.

\subsection{CHANGES IN THE LABORATORY AND ITS BUILT ENVIRONMENT}

\subsection{Management}

LLNL is a government-owned, contractor-operated (GOCO) entity. It is owned by the U.S. Department of Energy. The University of California managed it from its inception until 2007. In 2007, after 55 years, Lawrence Livermore National Security, LLC (LLNS), undertook the contract for management of LLNL.

The change in management has had no impact on the understanding of LLNL's earlier history. While the change will undoubtedly be understood as a turning point in LLNL's history, it is too early to assert a definitive change in direction. Certainly it is too early to determine any impact to the built environment. 


\subsection{Mission}

Since the end of the Cold War, the overall mission emphasis and resulting internal organization of the laboratory has undergone several changes. Since 2005, LLNL has grouped the mission into three areas:

- Nuclear Security, which includes stockpile stewardship, nuclear non-proliferation work, and prevention of nuclear terrorism;

- International and Domestic Security, which includes counter terrorism and other threat reduction capabilities, as well as military technologies; and

- Energy and Environmental Security, which includes climate change studies and the pursuit of technologies to enable a carbon-free energy future.

All three are key elements of national security and in that sense LLNL's core contribution and role in U.S. security remain consistent. However, the mission of nuclear weapons design and development, primary during the Cold War, is now transformed into the Nuclear Security mission and the other two mission elements sit on an equal footing with it.

\subsection{Current Emphases in Research Areas}

Within its mission areas, LLNL pursues a broad range of research activities. Much of the research has its roots in Cold War nuclear weapons work, but is not pursued exclusively in support of nuclear weapons. LLNL's inertial confinement fusion research, for example, has always had a dual purpose - creating an environment for weapons design and component testing (now identified as part of stockpile stewardship) and pursuing sustainable energy production. Similarly, LLNL's work in biosciences originated as part of the nuclear effects studies arena, but has evolved into a broader defense research area.

The shifting emphasis within LLNL's research is reflected in its organizational structure. For example, in 1992, the Nonproliferation, Arms Control, and International Security (NAI) directorate was formed, absorbing the former Military Applications directorate. The title and purpose of NAI directly addressed nuclear weapon proliferation as a major threat to national security. In 2005, reflecting U.S. concerns and focus after 9/11, LLNL created a Homeland Security organization tied to NAI; they were subsequently subsumed into a Homeland and International Security Directorate, which in turn segued into the 2007 Global Security Directorate. Global Security included the ever-critical nonproliferation activities, as well as energy research, and intelligence analysis and technologies. The national security threats LLNL currently addresses are much broader 
than the nuclear weapons defense and nonproliferation missions that were its focus at the end of the Cold War.

Changes in LLNL's research profile are relevant to cultural resources management at the Lab in that they may have an impact on the built environment. The research is housed within LLNL's buildings, which may or may not reflect that research. The National Ignition Facility (NIF), computing, Homeland Security, and the biosciences have received significant attention and produced notable results within the past decade; the buildings that house them therefore may prove historically significant in the long term.

The discussion below is not meant to exclude any areas of research from potential historical significance. Rather, it is meant to highlight areas that currently appear likely to be judged historically significant in the future. The intent is to provide pointers for future areas of assessment.

\subsubsection{National Ignition Facility}

NIF is the world's largest and highest-energy laser. It is the newest, largest, and most promising of LLNL's lasers built to pursue inertial confinement fusion (ICF). ICF research at LLNL extends back into the 1950s. The 2005 report defined most of the big lasers and accelerators used to pursue ICF as historically significant, although most were no longer extant at LLNL at that time. NIF itself is part both of that historical line of research pursuing sustainable energy gain and of NNSA's stockpile stewardship program.

Spin-offs from NIF research may also prove significant. The Laser Inertial Fusion Engine (LIFE) concept emerged at LLNL from physics and technology that went into designing NIF. LIFE's goal is to create self-sustaining power plants using nuclear waste as a fuel. LIFE and other research and development activities that emerge from NIF need to be considered in future assessments of LLNL's built environment.

NIF and the buildings that house it remain too young to be considered eligible for the NRHP. However, it should be re-evaluated every five years until it achieves its primary goal, is removed from service, or approaches 50 years of age, to ensure the capture of its role in history. NIF has already made noteworthy breakthroughs in support of its experimental mission and the research areas that feed and parallel its development (laser research, crystal growth, optics studies) have flourished. As time passes and historic perspective is gained, these should also be re-evaluated to determine their historic significance within the LLNL post-Cold War context. 


\subsubsection{Computing}

Computing at LLNL includes both infrastructure support and supercomputing. The former has not proven historically significant on its own - it is generally considered part of the overall operations of the site, along with infrastructure elements like utilities. The latter, however, ties LLNL to broader developments in computing, as both consumer and contributor.

While LLNL has always had cutting-edge computing at its disposal, the past two decades have seen a considerable expansion in the power, speed, and applications of computing in all areas of research. With the end of full-scale nuclear testing in 1992, modeling and simulation became ever more critical in nuclear weapon component design and stockpile maintenance. Breakthroughs in computing for simulation have, in turn, supported research in fields unrelated to nuclear weapons.

In 1995, President Clinton announced U.S. intention to pursue stockpile stewardship in the absence of nuclear testing. That same year, DOE instituted the Accelerated Strategic Computing Initiative (ASCI) to support the move from test-based to science- and simulation-based support of the Stockpile Stewardship Program (SSP), the purpose of which is to "maintain high confidence in the safety and reliability of the nuclear weapons stockpile in the absence of nuclear testing.",3

In terms of the built environment and assessment of NRHP eligibility, computing poses an interesting problem. The pace of this work is so fast that the machines are in and out of service in a matter of a few years and the buildings that house them are, for the most part, generic or representative of basic trends in commercial architecture. Without the machines, the buildings do not represent the accomplishments they once housed. As for the machines themselves, it is difficult to achieve enough perspective to reasonably judge their historical significance before they are removed from service. While breakthroughs are recognized and highly prized at the time they are made, they all do not stand out as necessarily historically significant over time. For example, computing speed records are honored within the international computing community, but with the exception of a few large barrier-crossing feats, previous speed achievements often seem minor in hindsight.

The nature of supercomputing drives frequent machine upgrades and replacements; often before any judicious assessment can be made of the work's significance and representation within the built environment. For example, IBM delivered the ASCI

\footnotetext{
${ }^{3}$ ASCI Software Quality Engineering: Goals, Principles, and Guidelines, DOE/DP/ASC-SQE-2000-FDRFT-
} VERS2, (Washington, D.C.: U.S. Department of Energy, 2001). 
computer ASC Purple in 2005; the machine soon realized the program's intention to perform 100 teraflop/s (trillions of floating point operations per second). 100 teraflop/s was considered the threshold for successful and reliable 3-dimensional simulation of nuclear weapons performance required to ensure the safety and reliability of the U.S. nuclear stockpile without nuclear testing.

Purple was removed from service in 2010, having come and gone from LLNL between the original historic building assessment's completion and the beginning of the reevaluation. At five years of age, its exceptional significance would be difficult to argue. Although Purple's achievements were clearly stated and well regarded, it is easy to envision the understanding of its importance shifting and readjusting as years pass and other achievements are compared to it and provide a broader perspective of its history.

\subsubsection{Homeland Security}

LLNL's work in emergency response and anti-terror studies pre-dates the country's post9/11 definitions of these fields. The 2005 report found that this work was not represented in the LLNL built environment. As time goes on, that may change.

In response to the attacks of 9/11, the U.S. established a new entity, the Department of Homeland Security (DHS), and pushed for an additional focus on anti-terrorism and emergency response within the national security activities within other agencies. LLNL introduced a Homeland Security Organization in 2005 and maintains ties with the DHS. LLNL's existing research in secure data processing, improved screening technologies, anti-terrorism, analysis and threat reduction, and several other areas were pulled together to support the post-9/11 security emphasis.

It is not altogether clear whether this research will coalesce into historically significant breakthroughs as part of a homeland security theme. If this research emphasis is sustained, however, any impact it might have on the LLNL built environment must be evaluated. At this point, the work is not apparent in the built environment and no buildings can be judged historically significant due to their associations with it.

\subsubsection{Biosciences}

LLNL's biosciences research history extends back into the early 1960s, when a biomedical research program started. That research focused on the biological effects of fallout from nuclear detonations. Ultimately, a biomedical division was established. The 2005 report, while deeming the work interesting, did not find it represented in the LLNL built environment. 
More recent developments in the biosciences may prove interesting to historians in the long-term. Currently, the Center for Accelerator Mass Spectrometry (CAMS) is garnering attention from scientists internationally. Dating from the late 1980s, CAMS is a postCold War capability within LLNL. LLNL researchers pursue biological studies using accelerator mass spectrometry (AMS), which measures concentrations of isotopes in small samples. In addition to studying the effects of carcinogens on humans and animals, researchers conduct radiocarbon dating for internal research and external customers. LLNL is not the only institution using AMS, but it is the only site in the U.S. that focuses on AMS for biological research. CAMS is still too young to be considered NRHPeligible. Later re-evaluations may find the properties that house AMS research historically significant.

\subsection{REVIEW OF THEMES}

\subsection{Local History and World War II}

In addition to the dominant nuclear weapons themes that appear in LLNL's history, the site sits within the broader Livermore context and has a history that extends back into World War II (WWII). Thus, the 2005 report asserted themes for Local History and WWII History, as follows:

Local History

- Ranching

- Viticulture

- Early Industrial Development

WWII History

- Naval pilot training

- Naval Air Station (NAS) support of the U.S. war effort

The 2005 report recommended that nothing at LLNL be considered NRHP eligible within these themes, primarily due to the complete difference in missions between LLNL and the surrounding community and the lack of integrity in the structures from WWII.

\subsection{Cold War}

The 2005 report focused primarily on LLNL in the Cold War period and established a full set of themes for the Cold War context, as follows. 
Cold War History

- Nuclear Weapons Design

o Weapons Design

○ Computing

- Nuclear Weapons Testing

- Nuclear Testing

○ High Explosives Testing

- Nuclear Research

- Nuclear Physics Research

- Nuclear Chemistry Research

- Nuclear Materials Research

- Non-weapons Research

- Nuclear Energy Research

- Nuclear Propulsion Research

- Plowshare

- Biomedical Research

These themes remain relevant and adequate. The understanding of LLNL's role in Cold War and its significance remain intact. The manner in which the themes are reflected in the built environment has similarly not changed.

\subsection{Post-Cold War}

The 2005 report established basic themes for the post-Cold War period, as follows.

- Nuclear Weapons Design

○ Computing

- Nuclear Weapons Testing

○ High Explosives Testing

- Nuclear Research

- Nuclear Physics Research

○ Nuclear Chemistry Research

- Nuclear Materials Research

- Non-weapons Research

- Nuclear Energy Research

○ Nuclear Propulsion Research

- Biomedical research 
These are expected to change or at least expand as time passes and the post-Cold War period is better understood. At this point, given the growth of various areas of research within LLNL since the Cold War's end, both Non-weapons Computing and Anti-Terror Research should be added to the list of themes within the Non-weapons Research category.

Undoubtedly, the understanding of LLNL's role in this period will keep evolving. The post-Cold War period will most likely be reconceived as time passes and defined less in juxtaposition to the Cold War and more as a context or set of historic contexts on its own. The name was originally acknowledging that the Cold War was a definable, recognizable period in history. LLNL had no other clear identity in the decade immediately following the end of the Cold War; however, as time passes, there may be a clearly identifiable transition period that would still be called the post-Cold War period. That period would presumably end and a new era in LLNL's history begin (or its association with a new period of history would be established). Alternatively, it may be that a new period is ultimately identified as beginning at the end of the Cold War-and the notion of a postCold War period would drop away. Determining that will take greater historic perspective than is currently available.

The 2015 re-evaluation should consider this period again. By 2020, clearer delineations of the time period will be established by historians, allowing for definite themes within which buildings from this era can be assessed.

\subsection{REVIEW OF BUILT ENVIRONMENT}

\subsection{Current List of Properties}

The list of LLNL properties from November 22, 2011, includes 684 items, with 465 at the main site, 5 offsite, and 214 at Site 300 . This includes permanent buildings, as well as temporary buildings, mobile structures, trailers, utilities, landscaping, storage tanks, fences, security elements, and all other elements of the LLNL built environment. The list is provided in Appendix I.

\subsection{No Further Evaluation Needed}

The re-evaluation eliminated properties that did not require further evaluation from the current building list as they will not be considered of historic interest unless associated with a historic person or part of a historic district based on the eligibility of a related structure housing technical activities. These included the following types of properties: 
- Structures built and used solely for storage;

- Shops or support structures;

- Office buildings and administrative support buildings;

- All buildings from 1990 forward, unless they are threatened and have housed technical programmatic activities;

- All trailers, mobile, or temporary buildings;

- All explosive vaults or bunkers (like the other support structures, these will be included in the district consideration of any potentially interesting structure with which they are associated);

- All utilities;

- All security posts and guard stations;

- All landscaping, fencing, roads, parking, sidewalks, lighting, electrical systems (including lines, generators, and transformers), gas systems, communication systems, sewers, retaining walls, storage tanks, and other supportive infrastructure elements, as none of these appear to be of interesting designs or uses within the LLNL environment;

- Any offsite buildings used by LLNL, but not owned by DOE; and

- Any structure that does not fit within the historic preservation themes established for the site.

In addition, all buildings previously consulted on and determined by LSO to be of no historic significance were excluded, with the exception of those that reached 50 years of age since the last evaluation; Building 111, Directors Office, which will be discussed below in consideration of the individuals associated with the building; and Buildings 112 and 262 and the Building 810 Complex (Buildings 810A, 810B, and 810C), which were inadvertently omitted from the building list used for the 2005 report. These will all be addressed below.

The resulting list of properties for re-evaluation is much reduced, as indicated in Table 1, which includes 74 buildings. The majority are those that have turned 50 since the 2005 report was completed; they will be addressed in Section 5.3, below. The remainder are those proposed eligible in 2005, the status of which are detailed in Section 5.4, and those requiring reconsideration because they were either omitted from the building list used in the 2005 report or otherwise require further discussion. These are discussed in Section 5.5 , which will also provide some detail on new construction and architectural design. 
Table 1: Properties Included in 2010 Re-Evaluation

\begin{tabular}{|c|c|c|c|}
\hline Site & Asset ID & Facility Name & $\begin{array}{l}\text { Facility } \\
\text { Age }\end{array}$ \\
\hline MAIN SITE & 111 & DIRECTORS OFFICE & 42 \\
\hline MAIN SITE & 112 & COMPUTER CENTER & 45 \\
\hline MAIN SITE & 115 & COMPUTATION FACILITY BLDG & 57 \\
\hline MAIN SITE & 116 & G.S & 53 \\
\hline MAIN SITE & 117 & COMPUTATION FACILITY BLDG & 58 \\
\hline MAIN SITE & 121 & PLS OFFICE & 56 \\
\hline MAIN SITE & 123 & AUDITORIUM & 53 \\
\hline MAIN SITE & 125 & WEST CAFETERIA & 52 \\
\hline MAIN SITE & 131 & ENGINEERING & 52 \\
\hline MAIN SITE & 162 & RESEARCH/CRYSTAL GTH & 51 \\
\hline MAIN SITE & 165 & OPTICS/DEVELOPMENT LAB & 53 \\
\hline MAIN SITE & 166 & DEVELOPMENT LAB & 51 \\
\hline MAIN SITE & 174 & PLS & 54 \\
\hline MAIN SITE & 194 & PLS & 53 \\
\hline MAIN SITE & 233 & MATERIALS MANAGEMENT & 51 \\
\hline MAIN SITE & 241 & VACANT & 51 \\
\hline MAIN SITE & 243 & VACANT & 52 \\
\hline MAIN SITE & 251 & VACANT & 55 \\
\hline MAIN SITE & 253 & HC DEPT OFFICES \& LABS & 52 \\
\hline MAIN SITE & 254 & HC BIO ASSAY LAB & 51 \\
\hline MAIN SITE & 261 & VACANT & 57 \\
\hline MAIN SITE & 262 & G.S & 53 \\
\hline MAIN SITE & 280 & VACANT & 55 \\
\hline MAIN SITE & 281 & LABORATORY & 55 \\
\hline MAIN SITE & 312 & IMF MANAGED FACILITY & 55 \\
\hline MAIN SITE & 327 & RADIOGRAPHY & 52 \\
\hline MAIN SITE & 331 & TRITIUM FACILITY & 52 \\
\hline MAIN SITE & 332 & PU FACILITY & 51 \\
\hline MAIN SITE & 343 & IMF MANAGED OFFICE/LAB FACILITY & 51 \\
\hline MAIN SITE & 391 & DEVELOPMENT LABS & 33 \\
\hline MAIN SITE & 431 & BEAM RESEARCH CENTER & 58 \\
\hline MAIN SITE & 435 & VACANT & 51 \\
\hline MAIN SITE & 436 & PLS SHIPPING/RECEIVING/STORAGE & 55 \\
\hline MAIN SITE & 446 & VACANT & 51 \\
\hline MAIN SITE & U119 & TELCOM NODE \#11 & 69 \\
\hline
\end{tabular}




\begin{tabular}{|c|c|c|c|}
\hline Site & Asset ID & Facility Name & $\begin{array}{c}\text { Facility } \\
\text { Age }\end{array}$ \\
\hline SITE 300 & 804 & STAGING AREA & 53 \\
\hline SITE 300 & 805 & INERT MACHNG/EXPLVS WST PACKNG & 54 \\
\hline SITE 300 & 806A & HE MACHINING & 54 \\
\hline SITE 300 & 806B & HE MACHINING & 54 \\
\hline SITE 300 & 807 & HE MACHINING & 50 \\
\hline SITE 300 & $809 \mathrm{~A}$ & HE PRESSING & 52 \\
\hline SITE 300 & $810 \mathrm{~A}$ & HE ASSEMBLY & 39 \\
\hline SITE 300 & $810 \mathrm{~B}$ & HE ASSEMBLY & 29 \\
\hline SITE 300 & $810 \mathrm{C}$ & ASSEMBLY STORAGE & 29 \\
\hline SITE 300 & 811 & VACANT & 52 \\
\hline SITE 300 & $812 \mathrm{~A}$ & VACANT & 51 \\
\hline SITE 300 & 813 & CHANGE HOUSE & 54 \\
\hline SITE 300 & 817A & HE PRESSING CONTROL ROOM & 54 \\
\hline SITE 300 & 817B & HE PRESSING CELL & 54 \\
\hline SITE 300 & 817D & HE PRESSING STORAGE & 54 \\
\hline SITE 300 & 817F & HE PRESSING OVENS & 54 \\
\hline SITE 300 & $817 G$ & HE PRESSING BOILERS & 54 \\
\hline SITE 300 & $817 \mathrm{H}$ & HE PRESSING INERT STORAGE & 54 \\
\hline SITE 300 & 825 & CHEM PROCESS FACILITY & 52 \\
\hline SITE 300 & 826 & CHEM PROCESS FACILITY & 50 \\
\hline SITE 300 & 827A & CHEMISTRY BLDG & 43 \\
\hline SITE 300 & $827 C$ & CHEM PROCESS FACILITY & 43 \\
\hline SITE 300 & 830 & VACANT & 54 \\
\hline SITE 300 & $832 \mathrm{~A}$ & STORAGE & 54 \\
\hline SITE 300 & $832 \mathrm{C}$ & STORAGE & 54 \\
\hline SITE 300 & 833 & EPD/ERD SERVICE-R\&D & 52 \\
\hline SITE 300 & 8340 & EPD/ERD SRVC-MNTRNG TF834 & 50 \\
\hline SITE 300 & $834 \mathrm{~A}$ & THERMAL TEST FACILITY & 51 \\
\hline SITE 300 & $834 \mathrm{~B}$ & VACANT & 51 \\
\hline SITE 300 & $834 \mathrm{C}$ & VACANT & 51 \\
\hline SITE 300 & 834D & VACANT & 51 \\
\hline SITE 300 & $834 \mathrm{E}$ & VACANT & 51 \\
\hline SITE 300 & $834 \mathrm{~F}$ & VACANT & 51 \\
\hline SITE 300 & $834 G$ & VACANT & 51 \\
\hline SITE 300 & $834 \mathrm{H}$ & THERMAL TEST FACILITY & 51 \\
\hline SITE 300 & 850 & VACANT & 51 \\
\hline
\end{tabular}




\begin{tabular}{|l|l|l|r|}
\hline \multicolumn{1}{|c|}{ Site } & \multicolumn{1}{|c|}{ Asset ID } & \multicolumn{1}{|c|}{ Facility Name } & \multicolumn{2}{c|}{$\begin{array}{c}\text { Facility } \\
\text { Age }\end{array}$} \\
\hline SITE $\mathbf{3 0 0}$ & $\mathbf{8 5 1 A}$ & FIRING FACILITY & $\mathbf{5 1}$ \\
\hline SITE $\mathbf{3 0 0}$ & $\mathbf{8 6 5}$ & VACANT & $\mathbf{2 9}$ \\
\hline SITE 300 & 895 & EPD/ORAD OFFICE & 51 \\
\hline
\end{tabular}

Note: Buildings that the 2005 report recommended as NRHP-eligible or part of a district are indicated in bold text.

\subsection{Technical Facilities Reaching $\mathbf{5 0}$ since $\mathbf{2 0 0 5}$ Review}

Criteria Consideration G of the Secretary of the Interior's guidelines for assessing historic properties requires that properties must be over 50 years old to be considered eligible for the NRHP, unless they are of exceptional significance. This means that the threshold for eligibility essentially drops from exceptional historic significance to historically significant for older properties. LLNL's building list indicates that 141 buildings or structures reached 50 years of age since the 2005 report was completed. Appendix II provides a list of all of them.

Most of the properties listed in Appendix II are infrastructure or other support structures that require no further evaluation at this time. Table 2 provides a list of those technical facilities and offices for technical programs that have turned 50 since 2005. Those previously recommended eligible or part of a historic district are in bold and will be addressed in Section 5.4, below.

Table 2. LLNL Technical Facilities Reaching 50 since 2005 Report

\begin{tabular}{|l|l|l|r|}
\hline \multicolumn{1}{|c|}{ Site } & Asset ID & \multicolumn{1}{|c|}{ Facility Name } & $\begin{array}{c}\text { Facility } \\
\text { Age }\end{array}$ \\
\hline MAIN SITE & 116 & G.S & 53 \\
\hline MAIN SITE & 123 & AUDITORIUM & 53 \\
\hline MAIN SITE & 131 & ENGINEERING & 52 \\
\hline MAIN SITE & 162 & RESEARCH/CRYSTAL GTH & 51 \\
\hline MAIN SITE & 165 & OPTICS/DEVELOPMENT LAB & 53 \\
\hline MAIN SITE & 166 & DEVELOPMENT LAB & 51 \\
\hline MAIN SITE & $\mathbf{1 7 4}$ & PLS & $\mathbf{5 4}$ \\
\hline MAIN SITE & 194 & PLS & 53 \\
\hline MAIN SITE & $\mathbf{2 4 1}$ & VACANT & $\mathbf{5 1}$ \\
\hline MAIN SITE & 243 & VACANT & 52 \\
\hline MAIN SITE & 251 & VACANT & 55 \\
\hline
\end{tabular}




\begin{tabular}{|c|c|c|c|}
\hline Site & Asset ID & Facility Name & $\begin{array}{l}\text { Facility } \\
\text { Age }\end{array}$ \\
\hline MAIN SITE & 253 & HC DEPT OFFICES \& LABS & 52 \\
\hline MAIN SITE & 254 & HC BIO ASSAY LAB & 51 \\
\hline MAIN SITE & 262 & G.S & 53 \\
\hline MAIN SITE & 327 & RADIOGRAPHY & 52 \\
\hline MAIN SITE & 331 & TRITIUM FACILITY & 52 \\
\hline MAIN SITE & 332 & PU FACILITY & 51 \\
\hline MAIN SITE & 343 & IMF MANAGED OFFICE/LAB FACILITY & 51 \\
\hline MAIN SITE & 435 & VACANT & 51 \\
\hline MAIN SITE & 436 & PLS SHIPPING/RECEIVING/STORAGE & 55 \\
\hline MAIN SITE & 446 & VACANT & 51 \\
\hline MAIN SITE & U119 & TELCOM NODE \#11 & 69 \\
\hline SITE 300 & 804 & STAGING AREA & 53 \\
\hline SITE 300 & 805 & INERT MACHNG/EXPLVS WST PACKNG & 54 \\
\hline SITE 300 & 806A & HE MACHINING & 54 \\
\hline SITE 300 & 806B & HE MACHINING & 54 \\
\hline SITE 300 & 807 & HE MACHINING & 51 \\
\hline SITE 300 & $809 \mathrm{~A}$ & HE PRESSING & 52 \\
\hline SITE 300 & 811 & VACANT & 52 \\
\hline SITE 300 & $812 \mathrm{~A}$ & VACANT & 51 \\
\hline SITE 300 & 813 & CHANGE HOUSE & 54 \\
\hline SITE 300 & 817A & HE PRESSING CONTROL ROOM & 54 \\
\hline SITE 300 & 817B & HE PRESSING CELL & 54 \\
\hline SITE 300 & 817D & HE PRESSING STORAGE & 54 \\
\hline SITE 300 & $817 F$ & HE PRESSING OVENS & 54 \\
\hline SITE 300 & $817 G$ & HE PRESSING BOILERS & 54 \\
\hline SITE 300 & $817 \mathrm{H}$ & HE PRESSING INERT STORAGE & 54 \\
\hline SITE 300 & 825 & CHEM PROCESS FACILITY & 52 \\
\hline SITE 300 & 830 & VACANT & 54 \\
\hline SITE 300 & 833 & EPD/ERD SERVICE-R\&D & 52 \\
\hline SITE 300 & 8340 & EPD/ERD SRVC-MNTRNG TF834 & 50 \\
\hline SITE 300 & $834 \mathrm{~A}$ & THERMAL TEST FACILITY & 51 \\
\hline SITE 300 & 834B & VACANT & 51 \\
\hline SITE 300 & $834 \mathrm{C}$ & VACANT & 51 \\
\hline SITE 300 & 834D & VACANT & 51 \\
\hline SITE 300 & $834 \mathrm{E}$ & VACANT & 51 \\
\hline SITE 300 & $834 \mathrm{~F}$ & VACANT & 51 \\
\hline
\end{tabular}




\begin{tabular}{|l|l|l|r|}
\hline \multicolumn{1}{|c|}{ Site } & Asset ID & \multicolumn{1}{|c|}{ Facility Name } & \multicolumn{2}{c|}{$\begin{array}{c}\text { Facility } \\
\text { Age }\end{array}$} \\
\hline SITE 300 & $834 \mathrm{G}$ & VACANT & 51 \\
\hline SITE 300 & $834 \mathrm{H}$ & THERMAL TEST FACILITY & 51 \\
\hline SITE 300 & $\mathbf{8 5 0}$ & VACANT & $\mathbf{5 1}$ \\
\hline SITE 300 & $\mathbf{8 5 1 A}$ & FIRING FACILITY & $\mathbf{5 1}$ \\
\hline SITE 300 & 895 & EPD/ORAD OFFICE & 51 \\
\hline
\end{tabular}

Structure U-119, telecommunications node \#11, although an infrastructure-support facility, is included on the list because it was not specifically addressed in the 2005 report. U-119 was built as part of the WWII NAS facilities at the site. It has retained the same function throughout its history. As illustrated in Figures $\mathbf{1}$ and 2, it is a small underground structure, accessed via concrete stairs. It is unremarkable except for its age (69 years). Its age alone does not lend it historic significance, however. As an infrastructure support facility that does not use any breakthrough technologies, it is not of historic interest on its own; as the rest of the WWII structures were found to lack integrity for their period of significance, there is no historic district to which it contributes. The recommendation is that U-119 is not NRHP-eligible.

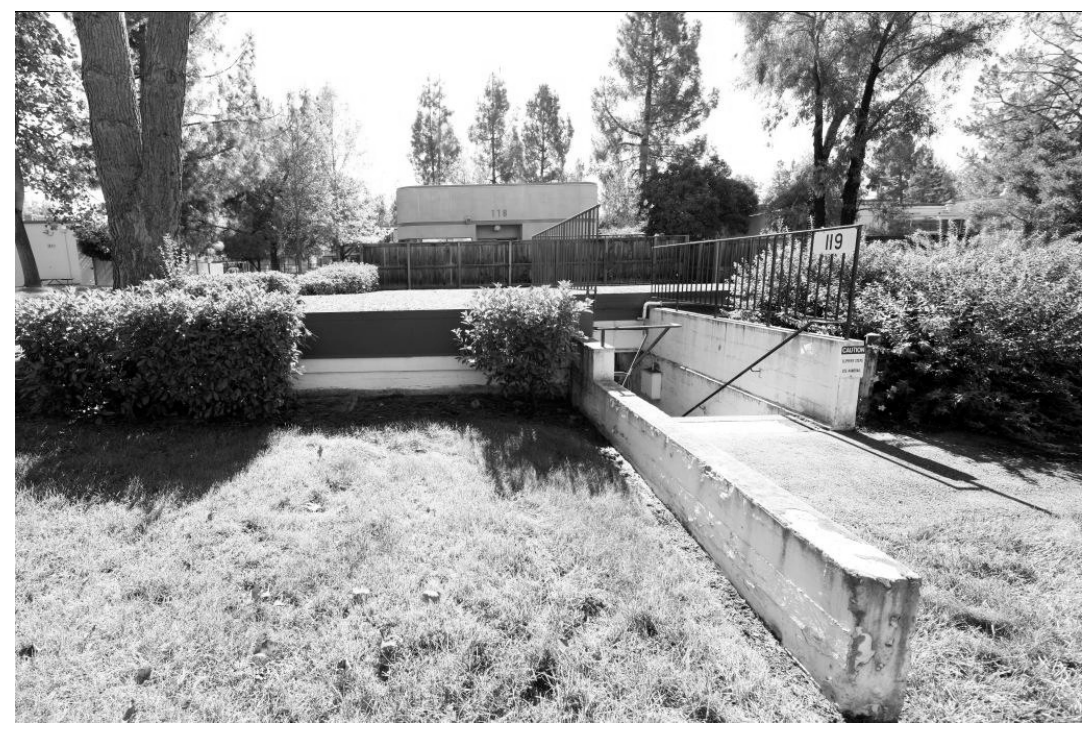

Figure 1. Entrance site to U-119, telecommunications facility, 2010 


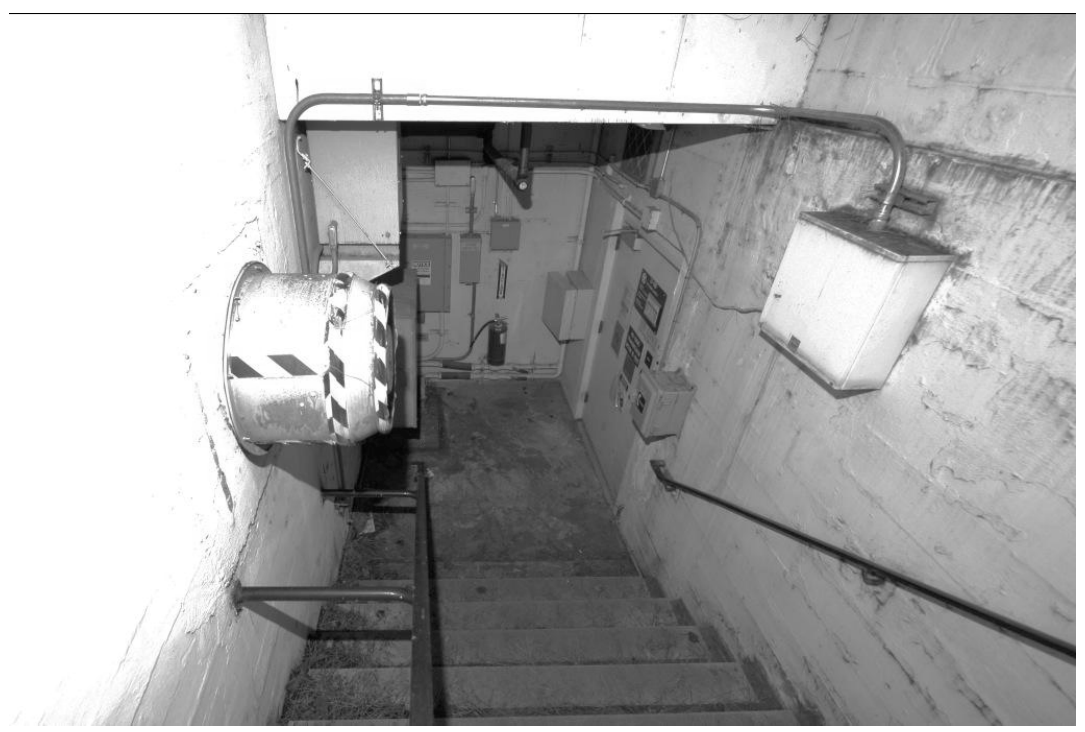

Figure 2. Concrete steps and steel door leading to U-119, 2010

The technical buildings that have turned 50 were originally assessed in consideration of their contributions to LLNL's Cold War work. Some were found to be historically significant, but lacking in integrity for their period of significance (Buildings 162, 166, $241,243,251,331,435,809 A)$. This conclusion is not changed by the buildings' ages. They no longer represent the original, historic work they housed.

The previous assessment did not identify anything that was historically significant but not of exceptional significance. A review of these buildings during the re-evaluation included consideration of the work they housed. No buildings that turned 50 since 2005 appear to meet the eligibility criteria for the NRHP that were not already eligible. The recommendation is that no buildings that have recently turned 50 be added to the NRHP eligible list for LLNL.

\subsection{Status of Existing NRHP-Eligible Properties}

The previous report recommended that five individual buildings, two sets of objects, and two historic districts be found eligible for the NRHP, as listed in Table 3. 
Table 3. Properties Recommended for NRHP Eligibility in 2005 Report

\begin{tabular}{|l|l|l|}
\hline \multicolumn{1}{|c|}{$\begin{array}{c}\text { Building, Object, or } \\
\text { District }\end{array}$} & \multicolumn{1}{|c|}{ Names of Properties Included } & \multicolumn{1}{|c|}{ Date Built } \\
\hline Building 194 & $\begin{array}{l}\text { 100-MeV Electron-Positron Linear } \\
\text { Accelerator Facility }\end{array}$ & 1958 \\
\hline Building 280 & Livermore Pool-Type Reactor & 1958 \\
\hline Building 332 & Plutonium Facility & 1961 \\
\hline Building 391 & Nova Facility & 1976 \\
\hline Building 865A & Advanced Test Accelerator & 1980 \\
\hline $\begin{array}{l}\text { Selected Objects in } \\
\text { Building 174 }\end{array}$ & Janus laser and control panel & 1974 \\
\hline $\begin{array}{l}\text { Selected Objects in } \\
\text { Building 241 }\end{array}$ & $\begin{array}{l}\text { Brew furnaces in Room 1600 of Building } \\
\text { 241 }\end{array}$ & 1960 \\
\hline $\begin{array}{l}\text { Site 300 Process Area and } \\
\text { Chemistry Area Historic } \\
\text { District }\end{array}$ & $\begin{array}{l}\text { Process Area and Chemistry Area: } \\
\text { Buildings 805, 806A, 806B, 807, 817A, } \\
817 B, 817 F, 825,826,827 A, 827 C\end{array}$ & 1957 \\
\hline $\begin{array}{l}\text { Site 300 Hydrodynamic } \\
\text { Test Facilities Historic } \\
\text { District }\end{array}$ & $\begin{array}{l}\text { Hydrodynamic Test Facilities Area: } \\
\text { Buildings 850 and 851A }\end{array}$ & 1955 \\
\hline
\end{tabular}

Review of the NRHP eligibility status and current work in the structures listed in Table 3 indicates that most are still eligible. The current status of the properties and the recommendations for their NRHP eligibility are summarized in Table $\mathbf{4}$ and detailed in Sections 5.4.1 and 5.4.2, below. 
Table 4. Current Status of Properties Considered NRHP-Eligible in 2005 Report

\begin{tabular}{|c|c|c|c|}
\hline $\begin{array}{l}\text { Building or } \\
\text { District }\end{array}$ & Description & Current Status & NRHP Eligibility \\
\hline Building 194 & $\begin{array}{l}\text { 100-MeV Electron-Positron } \\
\text { Linear Accelerator Facility }\end{array}$ & $\begin{array}{l}\text { Preservation via } \\
\text { documentation is underway. }\end{array}$ & NRHP Eligible \\
\hline Building 280 & Livermore Pool-Type Reactor & $\begin{array}{l}\text { Reactor and building are } \\
\text { inactive. No change since } \\
\text { original assessment. }\end{array}$ & NRHP Eligible \\
\hline Building 332 & Plutonium Facility & $\begin{array}{l}\text { Preservation via } \\
\text { documentation is complete. }\end{array}$ & $\begin{array}{l}\text { No longer NRHP } \\
\text { Eligible }\end{array}$ \\
\hline Building 391 & Nova Facility & $\begin{array}{l}\text { Preservation via } \\
\text { documentation is complete. }\end{array}$ & $\begin{array}{l}\text { No longer NRHP } \\
\text { Eligible }\end{array}$ \\
\hline $\begin{array}{l}\text { Building } 865 \\
\text { Complex }\end{array}$ & $\begin{array}{l}\text { Advanced Test Accelerator: } \\
\text { Buildings } 865 \mathrm{~A}, \mathrm{~B}, \mathrm{D}, \mathrm{E}, \mathrm{G} \text {, and } \\
\text { H }\end{array}$ & $\begin{array}{l}\text { Remains eligible. However, } \\
\text { was identified as Building } \\
865 \mathrm{~A} \text {; instead, should } \\
\text { encompass entire Building } \\
865 \text { Complex. }\end{array}$ & NRHP Eligible \\
\hline $\begin{array}{l}\text { Building } 174 \\
\text { Objects }\end{array}$ & Janus laser and control panel & $\begin{array}{l}\text { No change since original } \\
\text { assessment. }\end{array}$ & NRHP Eligible \\
\hline $\begin{array}{l}\text { Building } 241 \\
\text { Objects }\end{array}$ & $\begin{array}{l}\text { Brew furnaces in Room } 1600 \\
\text { of Building } 241\end{array}$ & $\begin{array}{l}\text { LSO consultation with CA } \\
\text { SHPO led to determination of } \\
\text { not historic }\end{array}$ & $\begin{array}{l}\text { Not NRHP } \\
\text { eligible }\end{array}$ \\
\hline $\begin{array}{l}\text { Site } 300 \text { Process } \\
\text { Area and } \\
\text { Chemistry Area } \\
\text { Historic District }\end{array}$ & $\begin{array}{l}\text { Process Area and Chemistry } \\
\text { Area: Buildings } 805,806 \mathrm{~A}, \\
806 \mathrm{~B}, 807,810 \mathrm{~A}, 817 \mathrm{~A}, 817 \mathrm{~B} \text {, } \\
817 \mathrm{~F}, 825,826,827 \mathrm{~A}, 827 \mathrm{C}\end{array}$ & $\begin{array}{l}\text { Added Building } 810 \mathrm{~A} \text { to } \\
\text { district elements }\end{array}$ & NRHP eligible \\
\hline $\begin{array}{l}\text { Site } 300 \\
\text { Hydrodynamic } \\
\text { Test Facilities } \\
\text { Historic District }\end{array}$ & $\begin{array}{l}\text { Hydrodynamic Test Facilities } \\
\text { Area: Buildings } 850 \text { and } 851 \mathrm{~A}\end{array}$ & $\begin{array}{l}850 \text { is now inactive; } 851 \mathrm{~A} \\
\text { remains in active use }\end{array}$ & NRHP eligible \\
\hline
\end{tabular}

\subsubsection{No Longer Eligible}

Building 241 objects (Brew Furnaces): LSO originally agreed with the 2005 report recommendation that the brew furnaces in Building 241 be considered NRHP-eligible. However, during consultation the California SHPO disagreed, pointing out that the brew furnaces were the last pieces of what had been a large, complex set of equipment and, as such, did not sufficiently represent Project Rover. On the basis of this input, LSO 
reconsidered and determined that the brew furnaces are not NRHP-eligible and should no longer be considered historic. ${ }^{4}$ The brew furnaces have been removed.

Building 391 (Nova Facility): Building 391 was preserved via recordation, including large-format photographs and a written report capturing the building's history and architectural features. ${ }^{5}$ The building remains part of LLNL's significant laser research and pursuit of nuclear fission as a support structure to NIF. As such, it has continued to evolve, housing new activities and new research machines. These changes are significant, transforming the building's interior sufficiently to undercut its integrity for its period of significance. In the future, it may again be part of historic events and be assessed as historically significant. At this time, however, it should not be considered NRHP-eligible.

\subsubsection{Still Eligible}

Building 174 (Janus laser and control panel): The Janus laser remains intact in Building 174. As laser research is a constantly evolving practice and the machines in use undergo frequent alterations, Janus is expected to lose integrity over time. LLNL anticipates preserving Building 174 and Janus via recordation. Once that has happened, Janus and Building 174 will continue to evolve, ultimately losing integrity for their established period of significance.

Building 194 (100 MeV Electron-Positron Linear Accelerator Facility): Building 194 is an active accelerator facility. As with laser research, accelerator research is an active field, requiring frequent alterations to machines and experiments. LLNL's plans include accelerators of very different design and capability than the $100 \mathrm{MeV}$ Electron-Positron Linear Accelerator. As a result, preservation via recordation of the building and the 100 $\mathrm{MeV}$ is underway. Large-format photography is complete and a draft report outlining the building's history and architectural features is underway. The building and the machines it houses will continue to evolve, eventually losing integrity for their period of significance.

\footnotetext{
${ }^{4}$ Milford Wayne Donaldson, State Historic Preservation Officer, California Office of Historic Preservation, to Karin L. King, Acting Deputy Director, Environmental Stewardship Division, National Nuclear Security Administration, Livermore Site Office, May 21, 2004; Carol Kielusiak to Brad Thomson, e-mail correspondence, August 9, 2004; and Milford Wayne Donaldson, California State Historic Preservation Officer, California Office of Historic Preservation, Letter of Concurrence, to Karin L. King, Acting Deputy Director, Environmental Stewardship Division, National Nuclear Security Administration, Livermore Site Office, April 5, 2005.

${ }^{5}$ Michael Anne Sullivan and Rebecca Ann Ullrich, "Lawrence Livermore National Laboratory, NOVA Building (Building 391): Written Historical and Descriptive Data, [and] Photographs" (Livermore: Lawrence Livermore National Laboratory, 2006).
} 
Building 280 (Livermore Pool-Type Reactor): The Livermore Pool-Type Reactor (LPTR) has not been used in research in decades. Building 280 is vacant, housing just the inactive reactor and its support equipment. LLNL expects to preserve Building 280 and the LPTR via recordation. Once preservation is complete, the building and the LPTR will be available to demolished.

Building 332 (Plutonium Facility): LLNL's Plutonium Facility remains intact, housing functions similar to and an extension of those conducted during its period of significance. The building and its operations were preserved via recordation with large-format photography and a written report of its history and architectural features. ${ }^{6}$ LLNL expects the building to remain in active use; it will be allowed to evolve as needed to support mission requirements. Ultimately, it may lose integrity for its period of significance.

Site 300: Building 865A (Advanced Test Accelerator [ATA]): The 865 Complex includes the main accelerator building, Building $865 \mathrm{~A}$, as well as several smaller support buildings (865B, D, E, G, and H) that are integrated into Building 865A's design and placed near it. Originally, the 865 Complex included Buildings 865A and seven support structures, Buildings 865B, C, D, E, F, G, and H. Based on a misunderstanding of a site sketch, the 2005 report incorrectly indicated that Building $865 \mathrm{E}$ had been demolished at an earlier date and only Buildings 865A, B, C, D, F, G, and H remained standing.

A site visit and review of the building drawings in 2010 clarified the Building 865 Complex layout. The complex includes Buildings 865A and 865E, which are connected by the narrow $865 \mathrm{~B}$, forming a long central structure that forms the bulk of the complex. Buildings $865 \mathrm{D}, \mathrm{G}$, and $\mathrm{H}$ are small buildings; they sit to the west of the long $865 \mathrm{~A}, \mathrm{~B}, \mathrm{E}$ structure. Buildings $865 \mathrm{C}$ and $\mathrm{F}$ were removed prior to the 2005 report. A current view of the 865 Complex is shown as Figure 3.

Most of the components of the ATA were removed from the experimental tunnel under Building 865A prior to the 2005 report; the final 10 cell blocks, and Blumleins on the second floor, were removed in the spring and summer of 2009 (respectively). Some additional Blumleins and equipment were removed earlier this year. The buildings in the complex do retain integrity, however, and reflect the accelerator research they once housed. The current recommendation is that the Building 865 Complex remains NRHP

\footnotetext{
${ }^{6}$ Michael Anne Sullivan and Rebecca Ann Ullrich, "Lawrence Livermore National Laboratory, Plutonium Facility (Building 332): Written Historical and Descriptive Data, [and] Photographs" (Livermore: Lawrence Livermore National Laboratory, 2008.)
} 
eligible. LLNL plans to preserve the complex via recordation. Once preservation is complete, the complex will be available to be demolished.

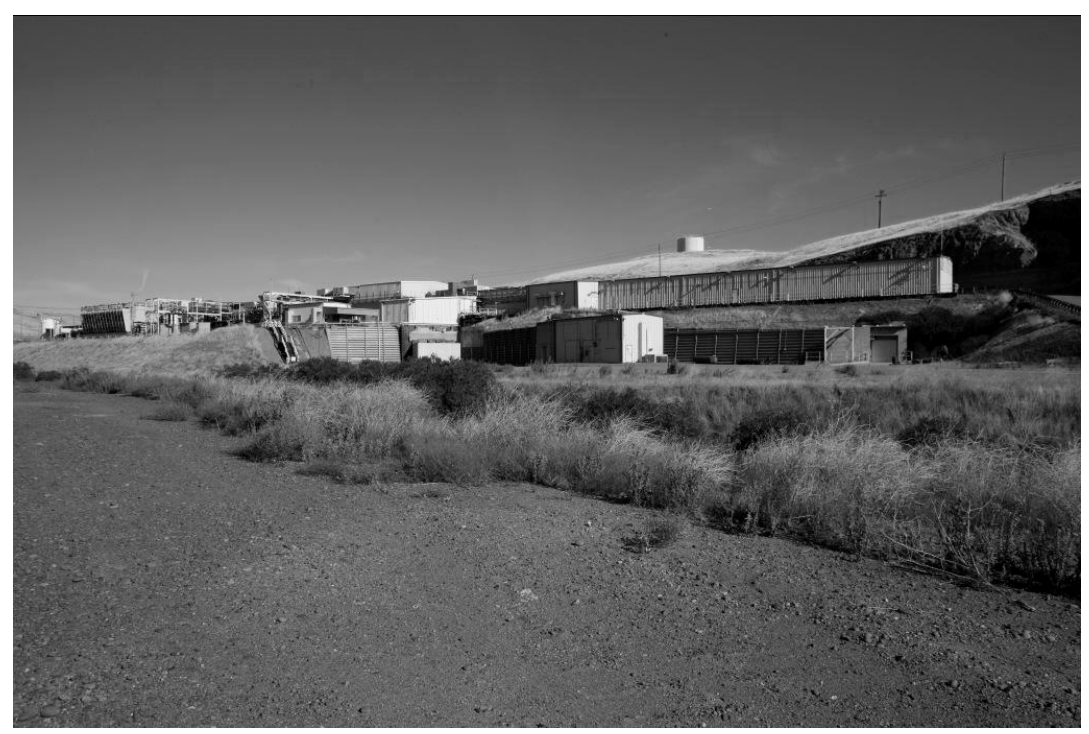

Figure 3. Building 865 Complex, 2010

Site 300: Process Area District (Buildings 805, 806A, 806B, 807, 817A, 817B, 817F, 825, $826,827 A, 827 C$ ): The Process Area and Chemistry Area remains in active use at LLNL's Site 300. The Building 817 Complex (Buildings 817A, B, and F) portion of the district was preserved via recordation, including large-format photography and a written report describing the history and architectural features of the buildings. ${ }^{7}$

The Building 817 Complex was recorded preparatory to the move of high explosives (HE) pressing activities to the refurbished Building 809 Complex. LSO previously determined that the buildings at the 809 complex were not eligible and not part of the Process Area and Chemistry Area Historic District. Building 809A was remodeled and a refurbished HE press installed. A new Building 809B was constructed at the site. Building $809 \mathrm{C}$ was refurbished and new ovens were installed. The boiler for the refurbished press did not work; the new ovens also did not work and were removed to storage. Buildings $817 \mathrm{~A}, \mathrm{~B}$, and $\mathrm{F}$ remain in service.

\footnotetext{
${ }^{7}$ Michael Anne Sullivan and Rebecca Ullrich, "Lawrence Livermore National Laboratory, Site 300 Process Area and Chemistry Area, High Explosive Pressing Complex (Buildings 817A, B, and F)" (Livermore, California: Lawrence Livermore National Laboratory, 2006).
} 
The 2005 report omitted the Building 810 Complex from its evaluation of the process area. The complex was assessed as part of this re-evaluation and is included as Appendix III. It recommends that Building $810 \mathrm{~A}$ be added to the Process Area and Chemistry Area Historic District, as it has been a key element in the overall HE processing activities at Site 300 from the Process Area's inception.

Site 300: Hydrodynamic Test Facilities Historic District (Buildings 850 and 851A): The two properties included in the Hydrodynamic Test Facilities Historic District remain intact. Building 850 is currently inactive, housing no research or testing activities. Anticipating the ultimate preservation of the historic district via recordation, large-format photographs were taken of Building 850 prior to closing it down. LLNL also cleaned and contoured the landscape around Building 850 as part of the environmental clean-up at the site. The bowl of hillside around the building currently presents a raw, terraced appearance, as illustrated in Figure 4; native grasses will cover the soil as time passes. The landscaping does not undercut the building's appearance or historic integrity and the district remains intact.

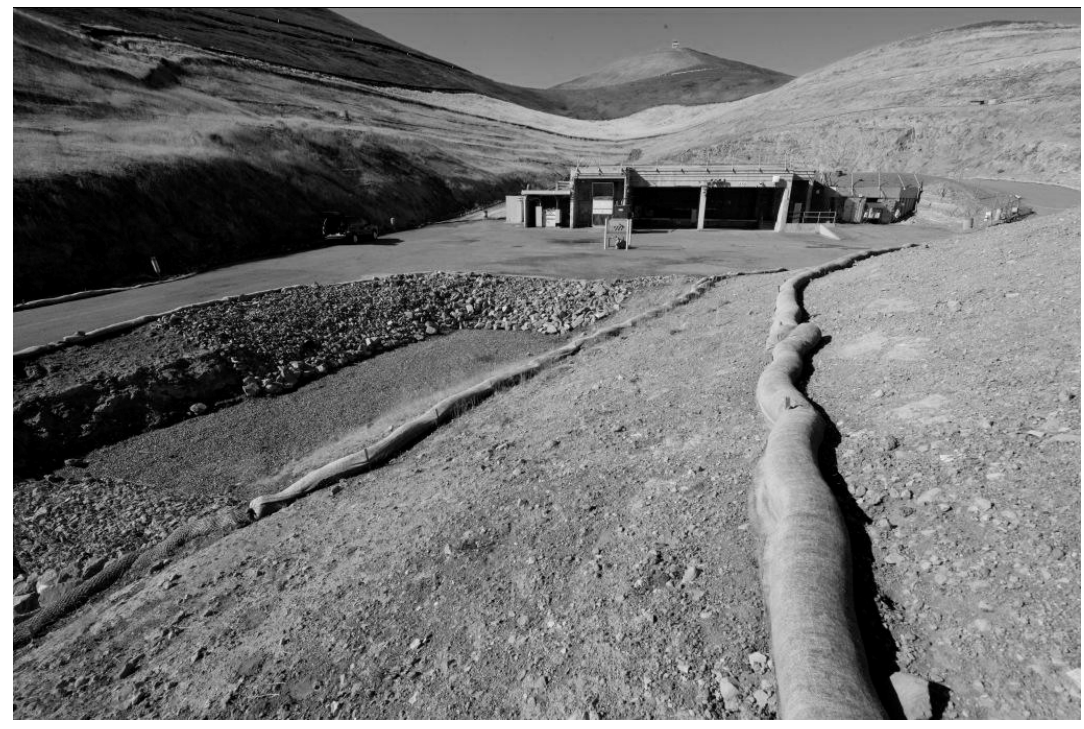

Figure 4. Landscaping of hillside and immediate area around Building 850, 2010

\subsection{New Considerations}

While LLNL has undertaken both demolition and new construction activities, the basic appearance and operations at both LLNL sites are intact and recognizable from the 2005 report. The changes in emphasis among the mission areas have not had a significant 
impact on the built environment in the five years since the original asses sment. The most notable anticipated impact to the environment is the introduction of more decorative features into new construction at the main site, which ultimately will alter the overall tone of the site's design.

\subsubsection{Demolition}

As LLNL is an active research and development facility, buildings and structures are removed when no longer needed, making space available for new facilities and cleaning up unused properties to avoid unnecessary future maintenance as well as reduction of the overall footprint of the Lab. No NRHP-eligible properties were demolished since completion of the 2005 report.

In terms of the physical appearance of LLNL, the most notable demolition effort was the removal of most of Building 212, Drill Hall. The building now has a much-reduced footprint, as the original drill hall portion of the facility was removed, leaving a large empty spot in its former location (Figure 5). Only the concrete elements with the accelerator-shielding block on the building's east end remain, as seen in Figure 6.

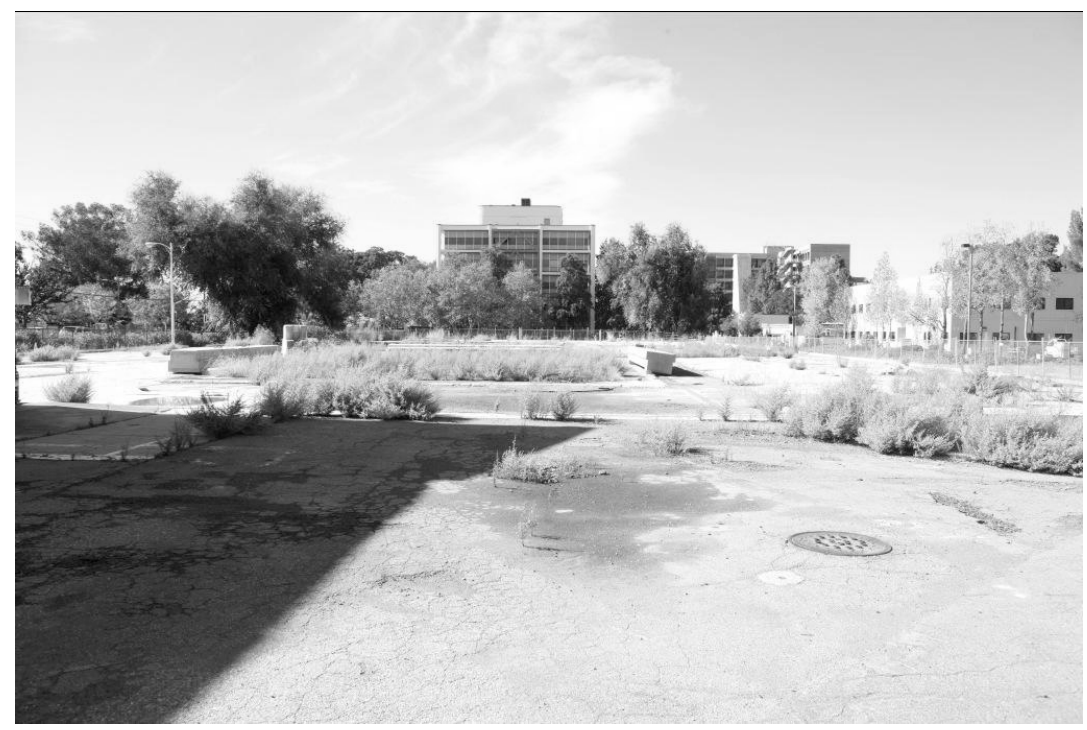

Figure 5. Empty fenced lot where the drill hall portion of Building 212 once stood, 2010 


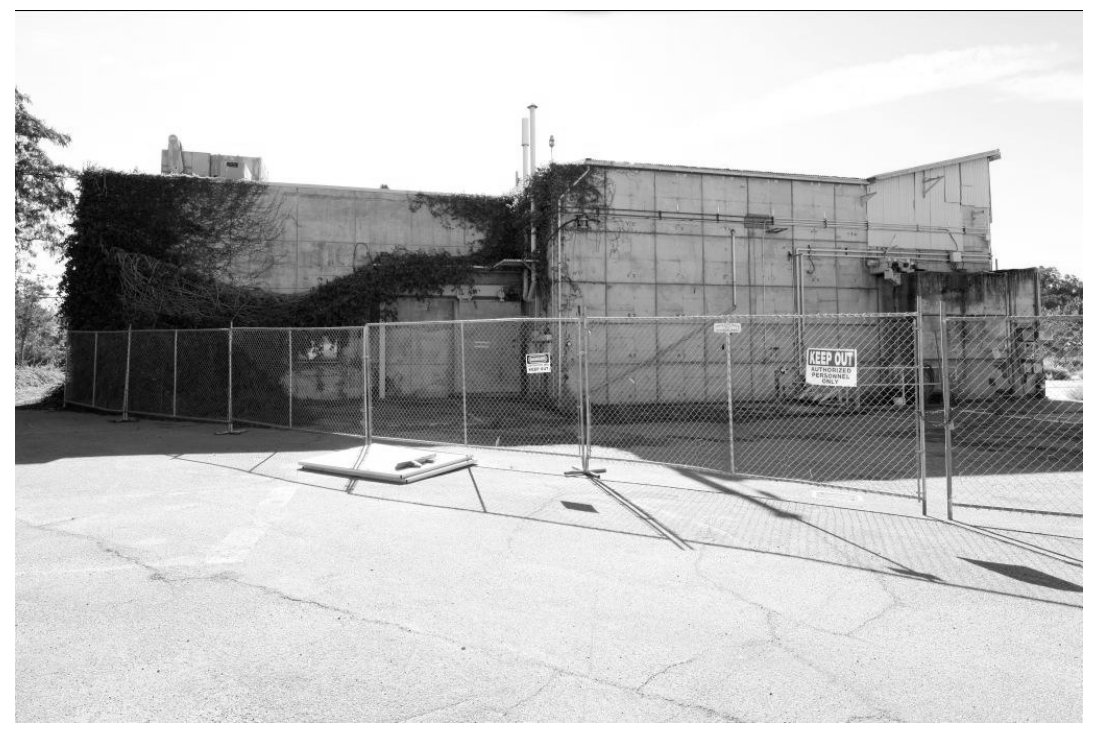

Figure 6. Much-reduced Building 212, 2010

\subsubsection{Construction}

The LLNL building list used in the 2005 report was from 2003 when the research for the original historic building survey and assessment began. Since then, 35 new buildings and structures have been constructed within the LLNL main site and Site 300, as listed in Table 5. The list includes both support facilities and technical, mission-related buildings housing scientific research and testing.

Table 5. LLNL Buildings Constructed, 2003-2010

\begin{tabular}{|l|l|l|r|r|}
\hline \multicolumn{1}{|c|}{ Site } & \multicolumn{1}{|c|}{$\begin{array}{c}\text { Asset } \\
\text { ID }\end{array}$} & \multicolumn{1}{|c|}{ Facility Name } & Facility Age & \multicolumn{1}{c|}{$\begin{array}{c}\text { Gross sq. } \\
\text { ft. }\end{array}$} \\
\hline MAIN SITE & 140 & G.S & 8 & 66,660 \\
\hline MAIN SITE & 142 & PLS OFFICE & 7 & 20,306 \\
\hline MAIN SITE & 155 & ISF OFFICE & 8 & 21,742 \\
\hline MAIN SITE & 242 & OFFICE & 7 & 20,328 \\
\hline MAIN SITE & 264 & ESH OFFICES & 6 & 20,461 \\
\hline MAIN SITE & 368 & G.S/BSL-3 LABORATORY & 6 & 1,590 \\
\hline MAIN SITE & 453 & TERA SCALE FACILITY & 7 & 240,598 \\
\hline MAIN SITE & 471 & CENTRAL CAFETERIA & 7 & 16,086 \\
\hline MAIN SITE & 581 & THE NATIONAL IGNITION FACILITY & 9 & 693,172 \\
\hline MAIN SITE & 583 & OFFICE & 5 & 21,793 \\
\hline MAIN SITE & 610 & TRUCK INSPECTION STATION & 7 & 4,314 \\
\hline MAIN SITE & 653 & EPD SAMPLE STAGING & 6 & 96 \\
\hline
\end{tabular}


Five-Year NRHP Re-Evaluation of Historic Building Assessment

\begin{tabular}{|c|c|c|c|c|}
\hline Site & $\begin{array}{l}\text { Asset } \\
\text { ID }\end{array}$ & Facility Name & Facility Age & $\begin{array}{c}\text { Gross sq. } \\
\text { ft. }\end{array}$ \\
\hline MAIN SITE & 3304 & TOILET TRAILER & 8 & 128 \\
\hline MAIN SITE & 4352 & ERD OFC-FIELD OPERATIONS & 9 & 240 \\
\hline MAIN SITE & 5675 & STAFF RELATIONS & 8 & 4,259 \\
\hline MAIN SITE & 6301 & RIGGER STORAGE & 7 & 732 \\
\hline MAIN SITE & 6929 & NIF OFFICE TRAILER & 6 & 4,759 \\
\hline MAIN SITE & 6930 & NIF OFFICE TRAILER & 6 & 5,892 \\
\hline MAIN SITE & 6931 & NIF CONSTRUCTION BREAKROOM & 2 & 1,405 \\
\hline MAIN SITE & 012D & EAST AVENUE SECURITY STORAGE & 5 & 205 \\
\hline MAIN SITE & $231 \mathrm{~A}$ & BEAD BLASTER-RECEIVING & 7 & 110 \\
\hline MAIN SITE & OS012A & SECURITY KIOSK & 8 & 26 \\
\hline MAIN SITE & OS012B & SECURITY KIOSK & 8 & 26 \\
\hline MAIN SITE & OS012C & SECURITY KIOSK & 8 & 26 \\
\hline MAIN SITE & OS231S & SECURITY KIOSK & 7 & 90 \\
\hline MAIN SITE & OS321E & SECURITY KIOSK & 7 & 54 \\
\hline MAIN SITE & OS454 & TSF COOLING TOWERS & 7 & 3,375 \\
\hline MAIN SITE & OS513 & E85 FUELING STATION & 3 & \\
\hline MAIN SITE & OS601 & GUARD KIOSK & 5 & 83 \\
\hline SITE 300 & 8580 & BREAKROOM TRAILER & 5 & 384 \\
\hline SITE 300 & $809 B$ & MECHANICAL SUPPORT & 8 & 617 \\
\hline SITE 300 & OS812P & MITIGATION POND & 6 & 0 \\
\hline SITE 300 & OSM10 & HE STORAGE MAGAZINE & 9 & 104 \\
\hline SITE 300 & OSM15 & HE STORAGE MAGAZINE & 9 & 120 \\
\hline SITE 300 & U849C & COMM RADIO TWR CNTRL BLDG & 9 & 336 \\
\hline
\end{tabular}

The buildings are all too young for NRHP eligibility. It is worth noting their presence and architectural design elements, however, in anticipation of understanding their impact on the overall site environment.

The support buildings and basic laboratories remain largely utilitarian in design, as reflected in Buildings 368 (Figure 7), 610 (Figure 8), and 653 (Figure 9). They are prefabricated metal buildings with no adornment or other architectural features of note. 
Five-Year NRHP Re-Evaluation of Historic Building Assessment

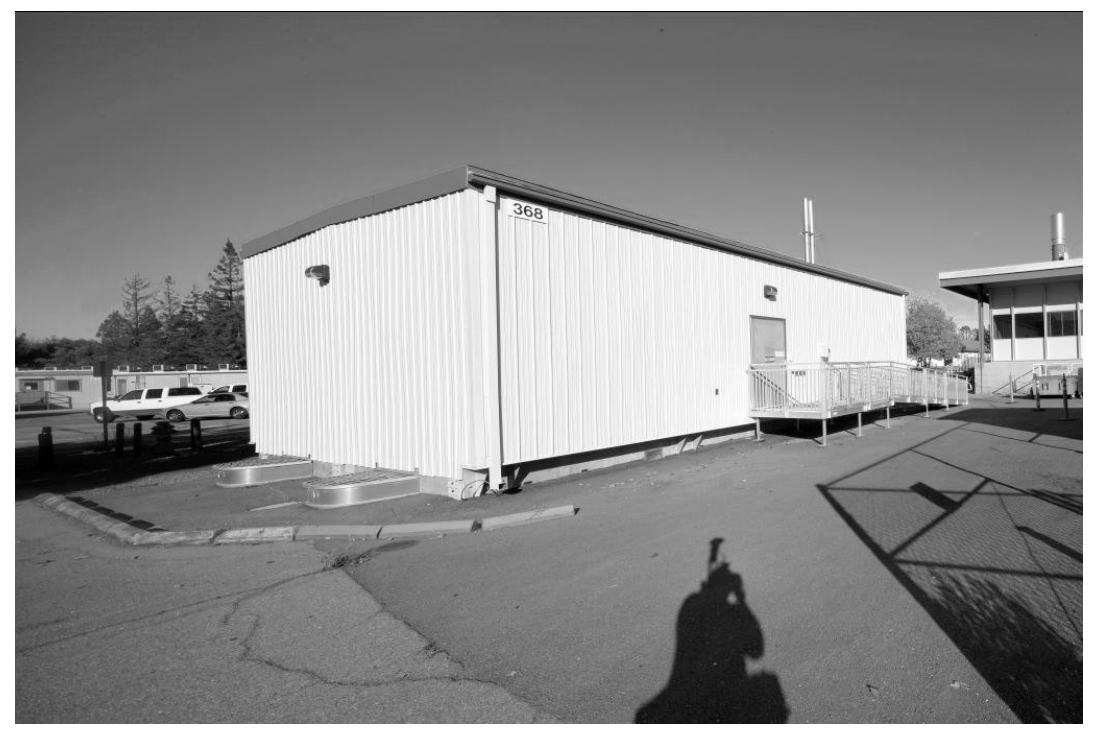

Figure 7. Building 368, BSL-3 laboratory, 2010

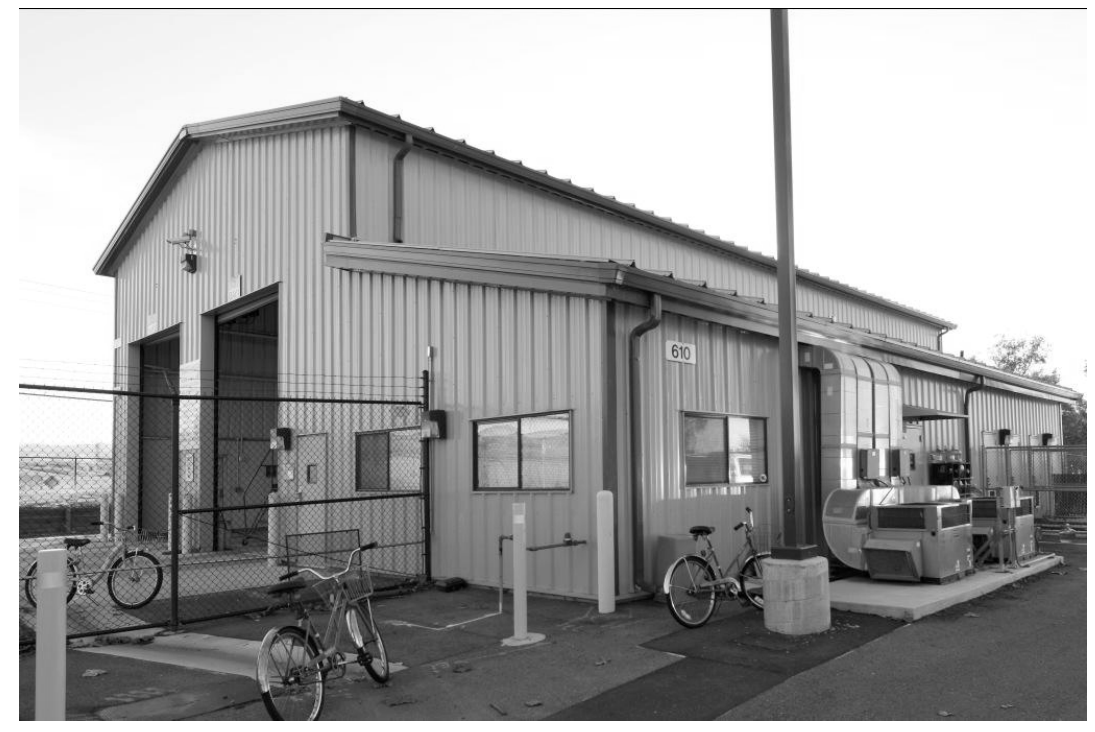

Figure 8. Building 610, truck inspection station, 2010 


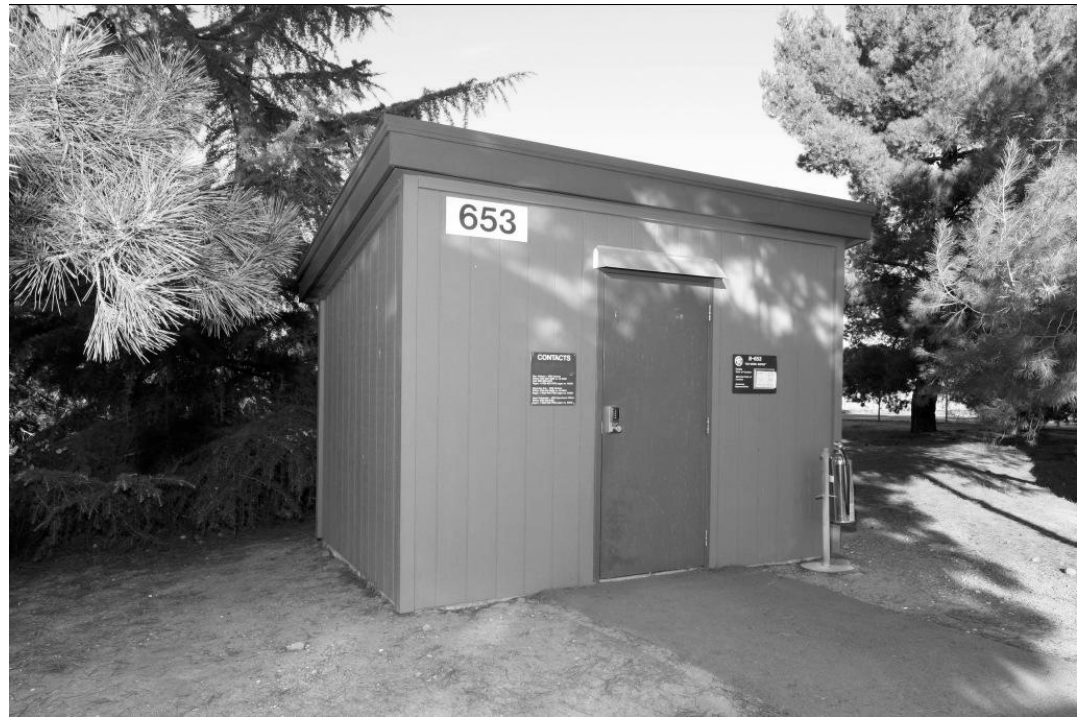

Figure 9. Building 653, sample-staging site, 2010

Office buildings and mission-related technical buildings reflect a more aesthetic design approach. This is a continuation of earlier design decisions, first articulated mildly in the 1968 Long-Range Master Development Plan, which suggested improving landscaping to make the environment more congenial for staff and visitors. This approach was expanded in the 1980s with wider use of decorative elements. Current designs make more use of glass and decorative trim, as well as larger, more impressive entrances, following on architectural design motifs introduced in the 1980s. As with earlier laser facilities and unlike older weapons facilities, these new buildings are meant to be attractive, displaying a concern with landscaping and the overall impression that buildings make on visitors and business partners.

Most of the new office buildings display clean lines and simple, unadorned, minor decorative features. Buildings 142, 242, and 264 are based on the same basic design by RMW Architecture \& Interiors. They feature slat awnings over east- and west-facing windows, as shown in Figures 10, 11, and 12. 


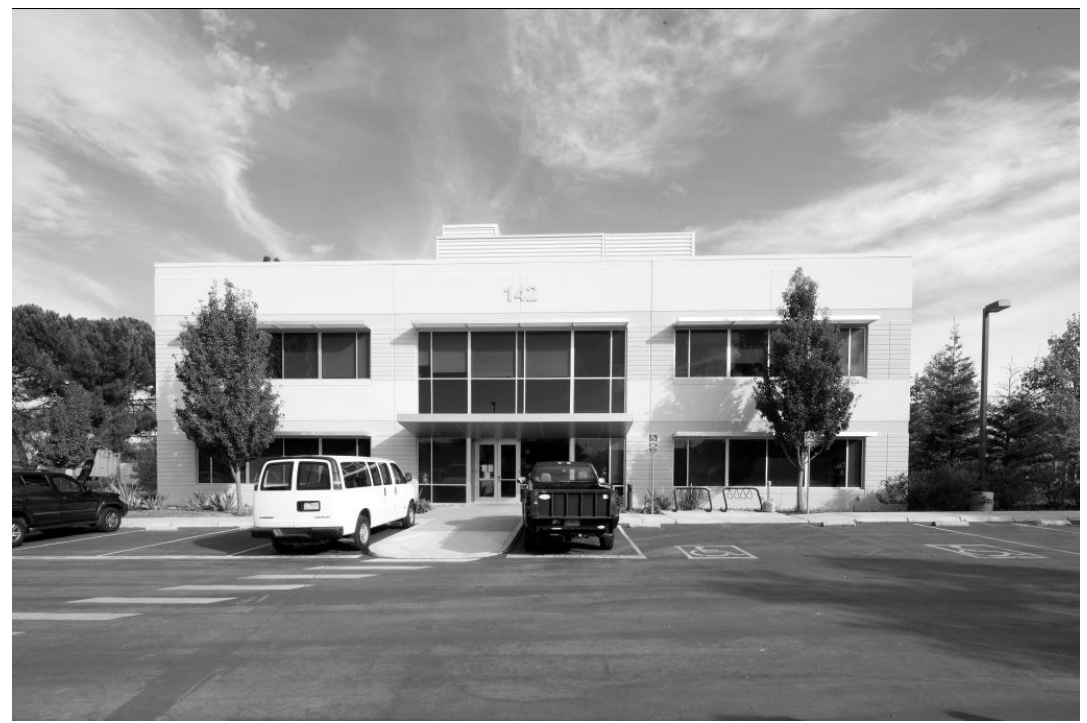

Figure 10. Building 142, office building, 2010

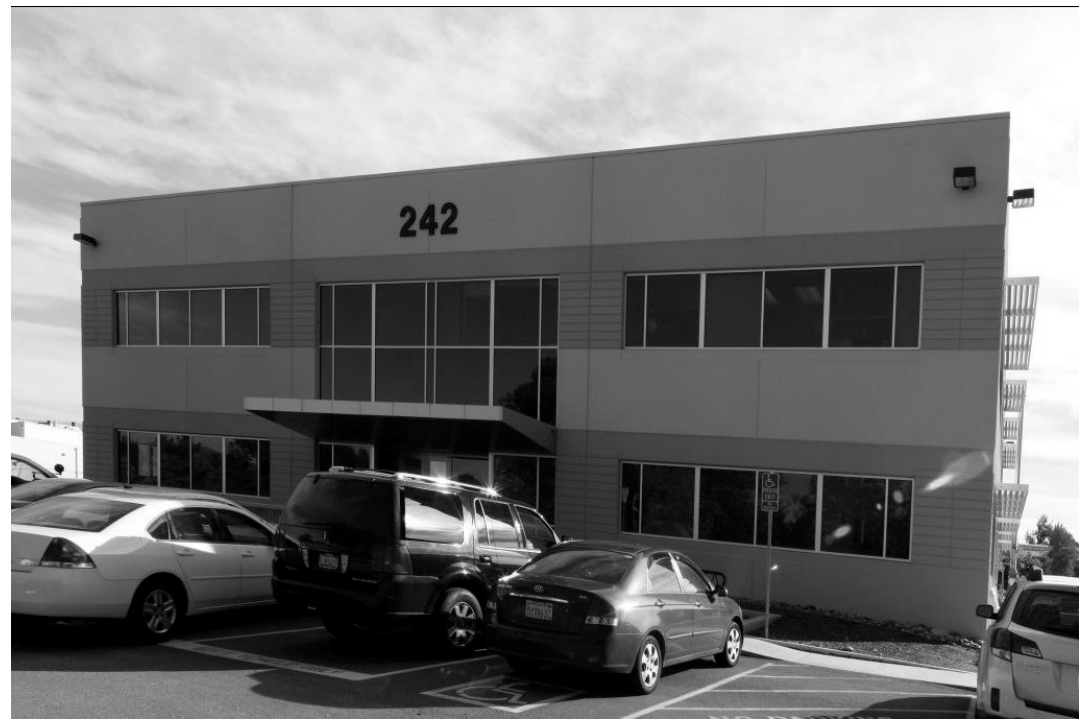

Figure 11. Building 242, office building, 2010 


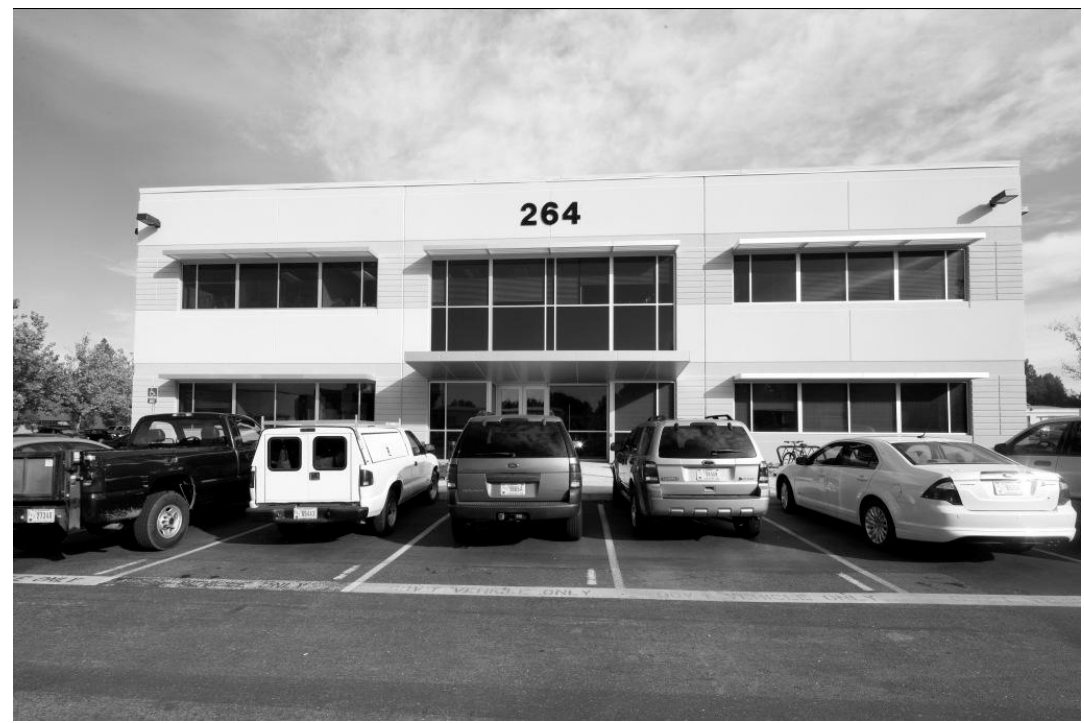

Figure 12. Building 264, office building, 2010

Other buildings, including the technical, mission-related buildings, display more distinctive designs with decorative features. They flaunt impressive, attractive entrances, and, as is popular in commercial architecture currently, use a variety of materials to achieve an eclectic, somewhat high-tech look. They are not necessarily consistent in design with other buildings near them. As shown in Figure 13, Building 155, housing offices, features a heavy, striated concrete exterior, with tall two-story window sections giving it a sense of height. Designed by Fong \& Chan Architects, the building is not massive, but feels monolithic due to its design. 


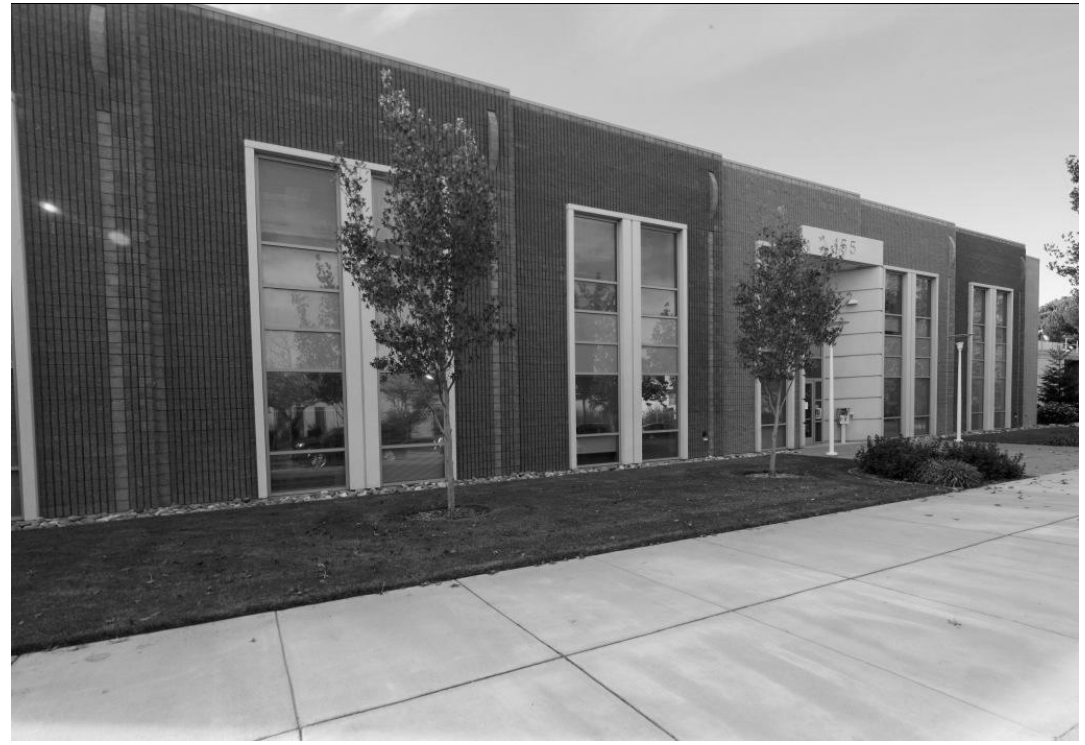

Figure 13. Building 155, ISF offices, 2010

Building 471, the central cafeteria, takes advantage of its location on the edge of Lake Haussman near the center of the LLNL main site, to present open, welcoming design. GEZ Architects Engineers designed it with a wraparound patio on the south to east sides, sloping roofs, and light colors, as illustrated in Figure 14.

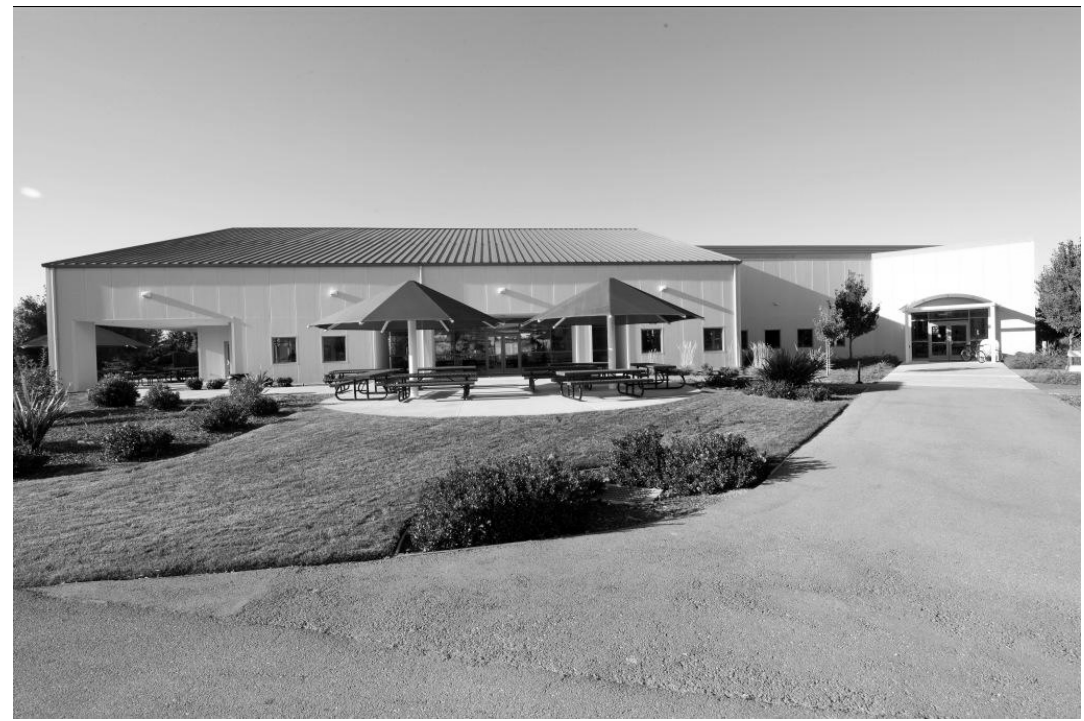

Figure 14. Building 471, central cafeteria, 2010 
Building 453, the Terascale Simulation Facility, is one of the more impressive of the new construction. Designed by RMW Architecture \& Interiors, the building displays a mix of materials and design elements. Different building sections rise to different heights and there are multiple sweeping features, such as the curved glass outer wall of the south section, that emphasize the building's size and gives it a sense of movement. Figures 15 and 16 display the building's architectural features; note the use of multiple types of materials and the sense of size presented by the glass on the south side in contrast to the more traditional International-Style lines of windows on the north side. The overall design projects significance, reflecting the importance currently placed on highperformance computing within LLNL.

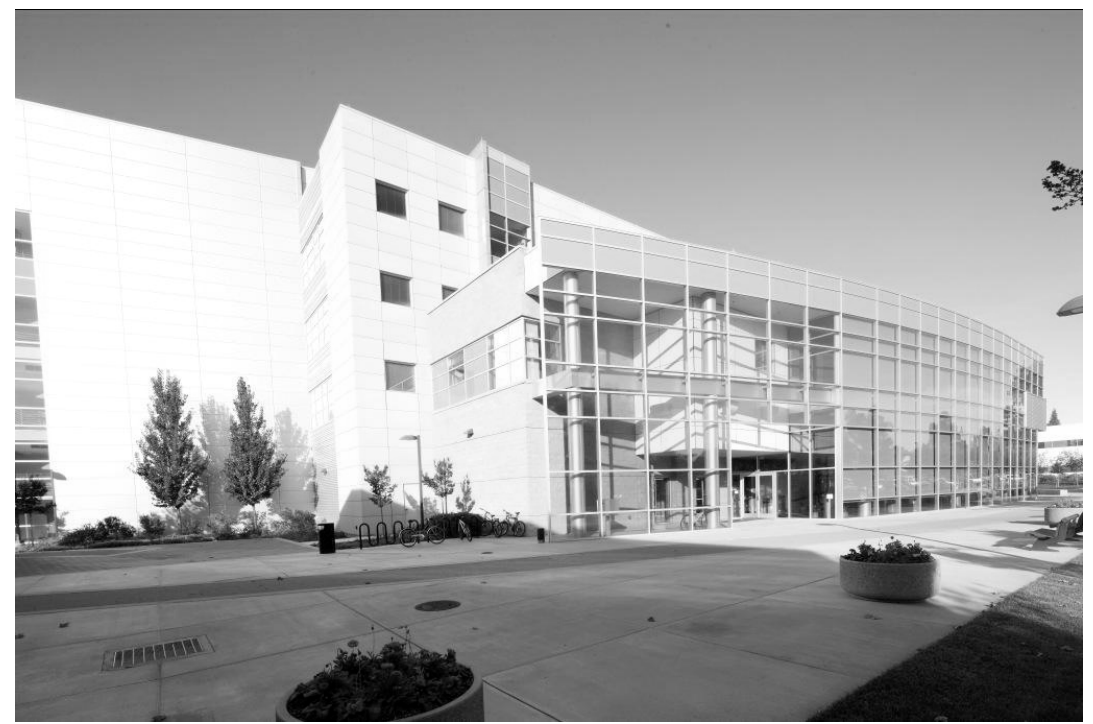

Figure 15. Building 453, Terascale Simulation Facility, south side, 2010 


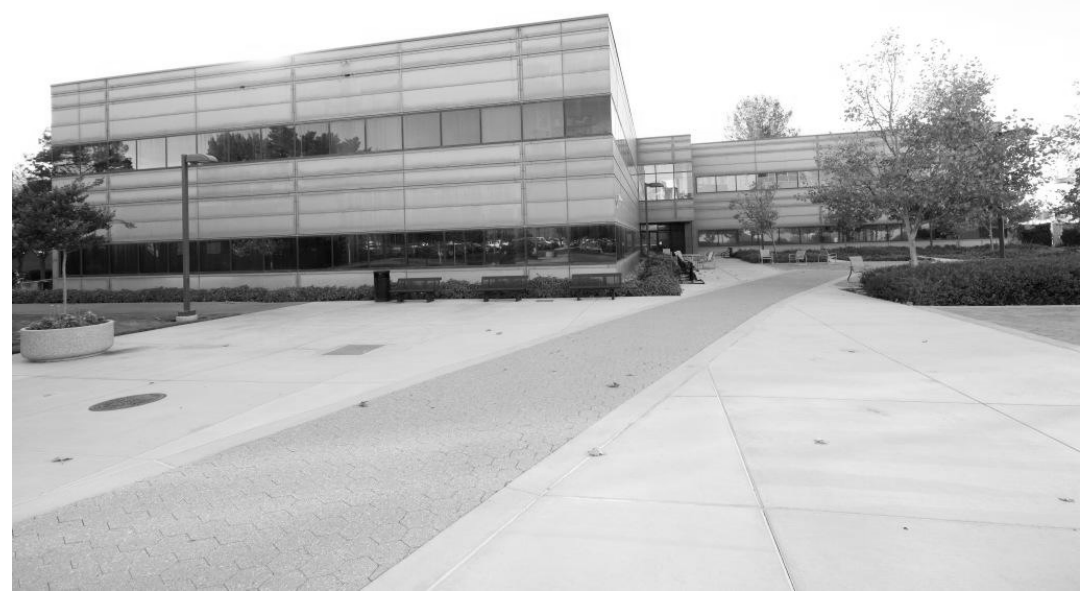

Figure 16. Building 453, Terascale Simulation Facility, north side, 2010

Buildings 581 and 583, both NIF facilities, reflect the earlier NIF designs and fit in well with the approach taken for laser fusion research. The buildings are large and basically unadorned, as illustrated in Figures 17 and 18. Their landscaping makes them approachable and their clean lines reflect a functional sensibility.

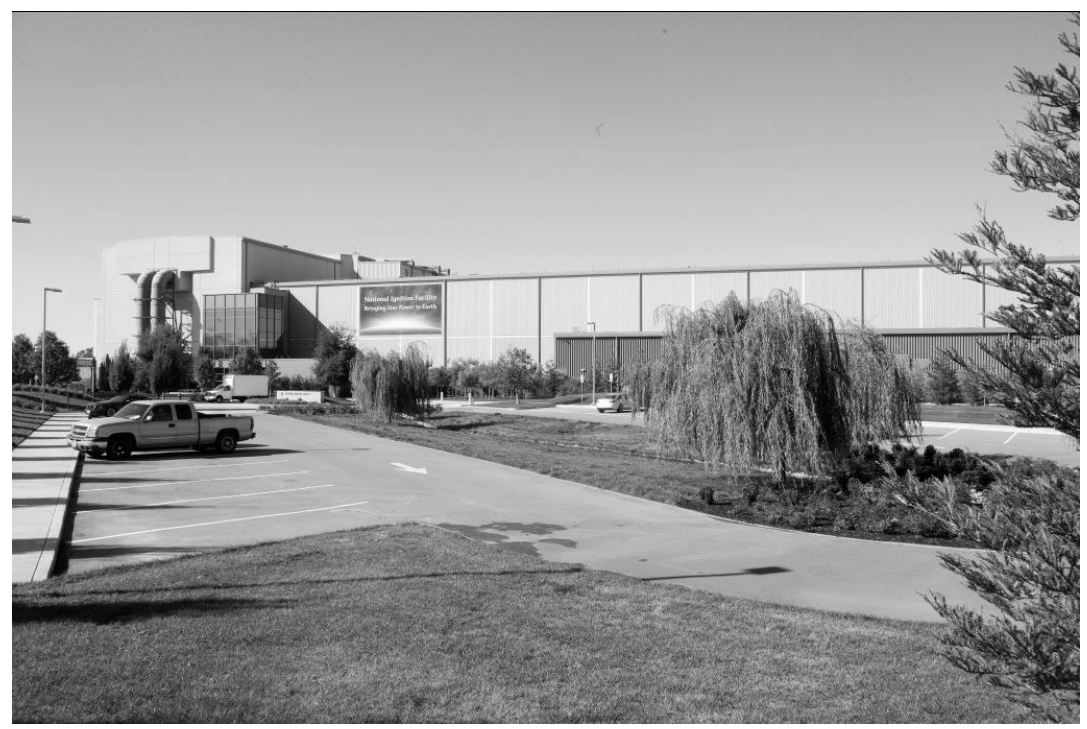

Figure 17. Building 581, National Ignition Facility, 2010 


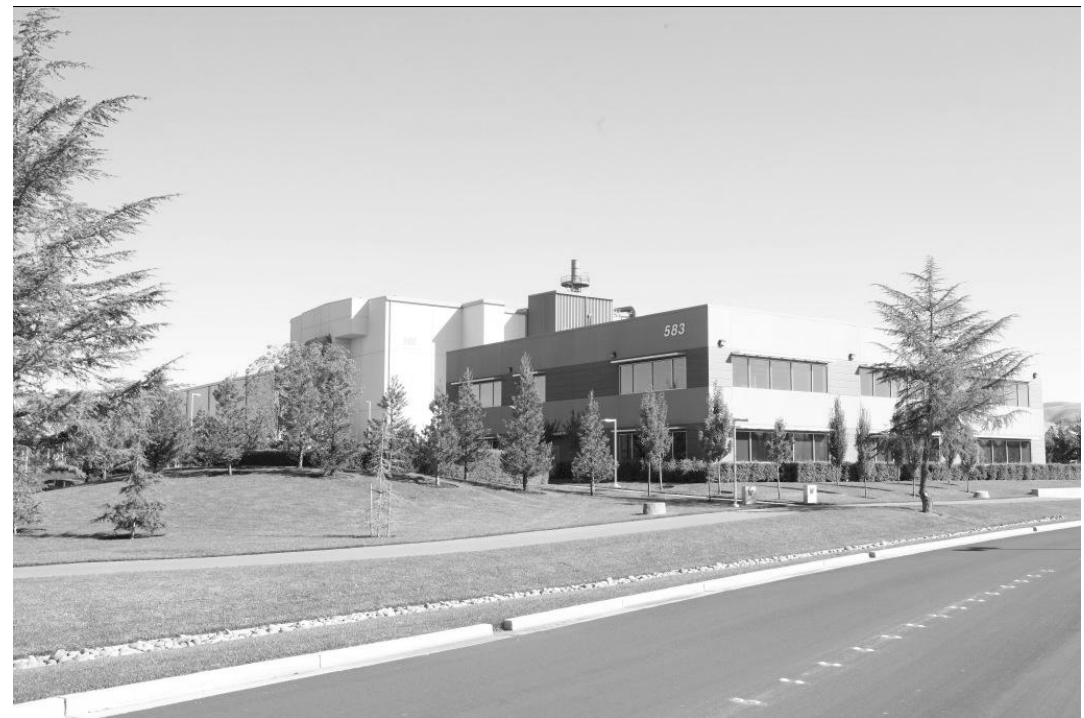

Figure 18. Building 583, NIF offices, 2010

\subsubsection{Reconsideration of Three Buildings from 2005 Report}

Three buildings covered by the survey included in the 2005 report need to be reconsidered in this re-evaluation. Building 111 needs to be re-evaluated periodically under Criterion $\mathrm{C}$ of the Secretary of the Interior's guidelines for assessing historic properties because it housed LLNL's laboratory directors from 1969 to the present. Buildings 112 and 262 were not on the building list used for the 2005 report.

Building 111: The 2005 recommendation regarding Building 111, the Director's Office, was that it not be considered NRHP eligible. While that evaluation under Criteria A, C, and $\mathrm{D}$ appears correct and unchanged by the events of the past five years, the passage of time requires periodic reconsideration of the building's elig ibility under Criterion B, association with a person or persons of recognized historical importance. LLNL's directors have been of consistently high caliber, having made noted contributions to their fields of study prior to rising in administration and serving as key LLNL figures while in the position of Laboratory Director. A few-Herbert York, Edward Teller, and John Foster, for example - are clearly recognized as figures important in national and international history. These early directors had offices in Buildings 161 and 121, neither of which retains any integrity for the period of the directors' occupancy.

Building 111 replaced Building 121 as the location for the Director's offices in 1969, when it opened. The directors who had offices there are Michael May (director 1965 - 
1971), Roger Batzel (1971-1988), John Nuckolls (1988-1994), C. Bruce Tarter (19942002), Michael Anastasio (2002-2006), and George H. Miller (2006-present). Of these, John Nuckolls has the clearest claim to being considered a historical figure. The others may be found to have broad national or international significance by later historians, but they do not appear in the historical literature in that manner at this time.

John Nuckolls is a key figure in the history of the science of controlled thermonuclear fusion, particularly inertial confinement fusion. His pioneering research makes him a key figure in establishing LLNL's laser fusion program. However, he is recognized not just for his role within LLNL, but for the contributions his LLNL research made to his field more broadly. He was critical in defining the research paths taken in laser fusion research. This work was conducted in the decades prior to his rise to the position of LLNL Director, and, although he was significant in the transition LLNL faced at the end of the Cold War, he is not a historical figure for work done while in Building 111. The laser fusion program research is housed elsewhere in buildings that have already been recognized as historically significant. The recommendation from this re-evaluation is that Building 111 is not eligible for the NRHP.

Building 112: The 2005 report based its evaluations on the LLNL building list, which at the time did not include Building 112. As Building 112 and 113 are connected, 112 was included as part of the evaluation of 113. Building 112, computer center, is pictured in Figure 19. The building is a steel-reinforced concrete structure with tilt-up exterior wall panels with a smooth finish. Since 2007, it has housed computing operations. The connected buildings were vacant when assessed for the 2005 report and did not reflect earlier work housed in them; the current computing work in the building is quite young and, while it should be evaluated as time passes, it does not appear to be historically significant at this time. The recommendation is that Building 112 not be considered eligible for the NRHP. 


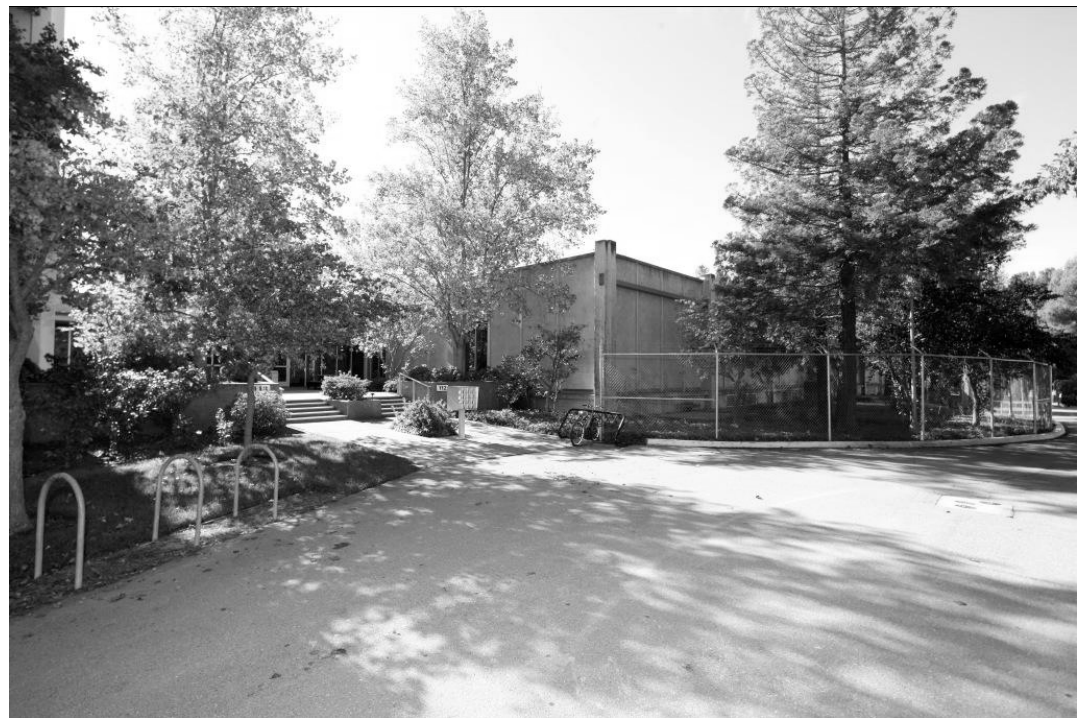

Figure 19. Building 112, computer center, 2010

Building 262: The building list used for the 2005 report did not include Building 262. As Building 261 and 262 are connected, 262 was included as part of the evaluation of 261. They housed Project Rover activities; neither retains integrity for that early research. The recommendation is that Building 262 not be considered eligible for the NRHP.

\subsubsection{Evaluation of Site as a Whole}

The 2005 report did not specifically address the question of the eligibility of the entirety of LLNL's main site or Site 300 to the NRHP. An overall site evaluation was conducted during the preparation of the report and the assessment of each specific building included its potential district eligibility; the main site and Site 300 as whole entities did not prove eligible in these assessments.

The following factors were central to the rationale for this recommendation:

- for those districts identified, the scope of the district was specified and in no cases did it coincide with the entire LLNL site or with all of Site 300,

- the current main site represents a mélange of historic and recent activities, as is to be expected of an active scientific facility, and

- the main site as a whole does not represent the historically significant events associated with the cold War themes identified in the historic context statement. 
This re-evaluation generated no additional information to alter this conclusion and the recommendation remains that the main LLNL site and Site 300 are not eligible for the NRHP as whole districts.

\subsection{CONCLUSION}

\subsection{Summary of Recommendations from Re-Evaluation}

This re-evaluation does not recommend significant changes to the list of NRHP-eligible buildings at LLNL. Both Building 391 and the Selected Objects in Building 241 (brew furnaces) should be removed from the list of eligible buildings. Building 810A should be added to the buildings included in the Site 300 Process Area District.

Minor adjustments should be made to the themes of the Post-Cold War historic context. More importantly, the Post-Cold War context should be re-evaluated in the long term.

Final recommendations from this re-evaluation are:

- No buildings need to be added to the list of individual buildings eligible for the NRHP;

- Building 810A should be added to the Site 300 Process Area and Chemistry Area Historic District;

- Buildings $810 \mathrm{~B}$ and Building $810 \mathrm{C}$ should not be included in the Site 300 Process Area and Chemistry Area Historic District, due to their age and lack of contribution to the early decades of explosive processing operations;

- Building 865 Complex, which includes Buildings 865A, B, D, E, G, and H, not Building $865 \mathrm{~A}$ alone, should be considered eligible;

- Building 332, which was determined by LSO in consultation with the California SHPO to be NRHP eligible, has been preserved via recordation, should be allowed to evolve as needed to meet LLNL's scientific mission requirements and not be considered NRHP-eligible any longer;

- Building 391, which was determined by LSO in consultation with the California SHPO to be NRHP eligible, has been preserved via recordation, has evolved significantly, and should no longer be considered NRHP-eligible for NOVA and the laser work that preceded it; and 
- Non-Weapons Computing and Anti-Terror Research should be added to the list of themes within the Non-Weapons Research category of the Post-Cold War context.

\subsection{Areas to Address in 2015 Re-Evaluation}

As always, upcoming evaluations should consider any major breakthroughs in LLNL's technical work and should consider any historical recognition of past events and people. Certainly any changes in the historical understanding of the Cold War should be addressed, as well as any refinements to the definition of the Post-Cold War context.

The 2015 five-year re-assessment should

- re-evaluate the eligibility of the main site and Site 300 for the NRHP as historic districts,

- consider any major breakthroughs and any historical recognition of past events or people,

- address the current status of buildings and districts previously found NRHP eligible,

- begin development of the post-Cold War context and provide a deeper understanding of relevant themes for LLNL within the post-1990 period, and

- begin assessing post-1990 buildings for exceptional significance, as the youngest of them will be 25 years old.

\subsection{REFERENCES}

Anastasio, Michael R. "Raymond J. Juzaitis Selected as Associate Director for Nonproliferation, Arms Control, and International Security and Acting Director for Homeland Security Organization." LLNL Administrative Memo 35:30 (June 29, 2005).

ASCI Software Quality Engineering: Goals, Principles, and Guidelines. DOE/DP/ASCSQE-2000-FDRFT-VERS2. Washington, D.C.: U.S. Department of Energy, 2001.

"Building Numbers at Livermore Site to Change Aug. 1." The Magnet, July 1967, 3.

“Doesburg Realigns Global Security.” Newsline, February 22, 2008.

“Doesburg Unveils Global Security Leadership Team.” Newsline, August 1, 2007. 
Heidecker, Kelly, and Paul McGuff. "Draft Programmatic Agreement among the Department of Energy and the California State Historic Preservation Officer Regarding Operation of Lawrence Livermore National Laboratory.” Livermore, California: LLNL, June 2011.

MacKenzie, Donald. "The Influence of the Los Alamos and Livermore National Laboratories on the Development of Supercomputing." Annals of the History of Computing 13:2 (1992): 179-201.

“Mike May Concludes Lab Career; To be Honored.” Newsline, January 18, 1989, 1, 4.

“New Buildings Completed at Site 300.” The Magnet, June 1959, 3.

Nuckolls, John H. "Creation of Nonproliferation/Arms Control/International Security Directorate." Administrative Memo 22:43 (July 6, 1992).

“‘Parney’ Albright named Global Security Leader.” Newsline, November 5, 2009.

“Purple supercomputer fades to black.” Newsline, November 9, 2010.

“Reis Honors Nuckolls with Top DOE Award.” Newsline, January 19, 1996, 1, 4.

“Sad Lab Loss.” Tri-Valley Herald, August 20, 2000.

Stark, Anne M. "John Doesburg Outlines Evolution of Global Security.” Newsline, June $22,2007,3$.

Sullivan, Michael Anne, and Rebecca Ann Ullrich. Historic Context and Building Assessments for the Lawrence Livermore National Laboratory Built Environment. UCRL-TR-234717. Livermore, California: Lawrence Livermore National Laboratory, 2007.

Sullivan, Michael Anne, and Rebecca Ann Ullrich. "Lawrence Livermore National Laboratory, NOVA Building (Building 391): Written Historical and Descriptive Data [and] Photographs." Livermore: Lawrence Livermore National Laboratory, 2006.

Sullivan, Michael Anne, and Rebecca Ann Ullrich. "Lawrence Livermore National Laboratory, Plutonium Facility (Building 332): Written Historical and Descriptive Data [and] Photographs." Livermore: Lawrence Livermore National Laboratory, 2010 . 
Sullivan, Michael Anne, and Rebecca Ullrich. "Lawrence Livermore National Laboratory, Site 300 Process Area and Chemistry Area, High Explosive Pressing Complex (Buildings 817A, B, and F)." Livermore, California: Lawrence Livermore National Laboratory, 2006.

Tarter, Bruce. "Tarter Looks to the Future." Newsline, June 28, 2002, 1, 6-8.

U.S. Department of the Interior, National Park Service, and Interagency Resources Division. National Register Bulletin 15: How to Apply the National Register Criteria for Evaluation. Washington, D.C.: GPO, 1990. . National Register Bulletin 39: Researching a Historic Property. Washington, D.C.: GPO, 1991.

"World's Largest Laser Sets Records for Neutron Yield and Laser Energy." Newsline, November 8, 2010. 


\section{Appendix I. List of All Buildings and Structures at LLNL Main Site and Site $\mathbf{3 0 0}$}

\begin{tabular}{|c|c|c|c|c|}
\hline Site & Asset ID & Facility Name & $\begin{array}{c}\text { Facility } \\
\text { Age }\end{array}$ & $\begin{array}{l}\text { Gross } \\
\text { Sq Ft }\end{array}$ \\
\hline MAIN SITE & 002LS & LANDSCAPING & & \\
\hline OFF SITE & $003 \mathrm{~A}$ & S PROGRAM & 1 & 3,750 \\
\hline OFF SITE & 008 & LLNS OFF-SITE OFFICE & 4 & 3,156 \\
\hline MAIN SITE & 012D & EAST AVENUE SECURITY STORAGE & 5 & 205 \\
\hline MAIN SITE & 021CA & CMPRSSED AIR SYS COMPRESSOR CTRL & & \\
\hline MAIN SITE & $022 \mathrm{CA}$ & CMPRSSED AIR SYS COMPRESSOR CTRL NW & & \\
\hline MAIN SITE & 023CA & CMPRD AIR SYS DIST LINES & & \\
\hline MAIN SITE & $02 \mathrm{AL}$ & SITEWIDE ACCELERATORS & 34 & \\
\hline MAIN SITE & $02 C N D$ & RETURN LINES / CONDENSATE & & \\
\hline MAIN SITE & 02CSL & COMM SYSTEM LINES & & \\
\hline MAIN SITE & 02EDT & ELECTRIC DIST TRANSFORMERS & & \\
\hline MAIN SITE & 02EGU & UTIL ELECT GENERATORS & & \\
\hline MAIN SITE & 02EPL & UTIL ELEC PRI DIST LINES & & \\
\hline MAIN SITE & 02EPT & ELEC POWER TRANSFORMERS & & \\
\hline MAIN SITE & 02ESL & UTIL ELEC SEC DIST LINES & & \\
\hline MAIN SITE & 02FAS & FIRE ALARM SYSTEM & & \\
\hline MAIN SITE & 02FNC & ALL OTHER FENCES & & \\
\hline MAIN SITE & 02GAWR & GARAGE AUTO WASH RACK & & \\
\hline MAIN SITE & 02GSDL & GAS SYS DIST LINES & & \\
\hline MAIN SITE & 02LGS & UTIL ELECT SUBSTATIONS & & \\
\hline MAIN SITE & 02LLIX & LLIX CABLE SYSTEM & & \\
\hline MAIN SITE & 02MFEST & ERD STORAGE AREA & & \\
\hline MAIN SITE & 02OST & STORAGE OIL TANKS TO-1 & & \\
\hline MAIN SITE & 02PRK & ALL OTHER PARKING AREAS & & \\
\hline MAIN SITE & 02RDP & ROADS PAVED & & \\
\hline MAIN SITE & 02RDU & ROADS UNPAVED \& IMPROVED & & \\
\hline MAIN SITE & 02RTW & RETAINING WALLS & & \\
\hline MAIN SITE & 02SAS & SECURITY ALARM SYSTEM & & \\
\hline MAIN SITE & $02 \mathrm{SCL}$ & ALL OTHER SECURITY LIGHTG & & \\
\hline MAIN SITE & 02SCSG & SEWER COLL SYST GRAVITY & & \\
\hline MAIN SITE & 02STL & ALL OTHER STREET LIGHTING & & \\
\hline MAIN SITE & 02STM & SUPPLY LINES / STEAM & & \\
\hline
\end{tabular}




\begin{tabular}{|c|c|c|c|c|}
\hline MAIN SITE & 02SWCS & STORM WATER COLL SYS GRAV & & \\
\hline MAIN SITE & 02SWP & ALL OTHER SIDEWALKS \& PATHS & & \\
\hline MAIN SITE & 02TS & TRUCK SCALE & & \\
\hline MAIN SITE & 02WRS & WASTE RETENTION SYSTEM & & \\
\hline MAIN SITE & 041 & LONG TERM STORAGE & 24 & 25,555 \\
\hline MAIN SITE & 071 & WESTGATE BADGE OFFICE & 19 & 4,166 \\
\hline MAIN SITE & 110 & STORAGE & 20 & 153 \\
\hline MAIN SITE & 111 & DIRECTORS OFFICE & 42 & 112,418 \\
\hline MAIN SITE & 112 & COMPUTER CENTER & 45 & 45,512 \\
\hline MAIN SITE & 113 & G.S & 45 & 44,426 \\
\hline MAIN SITE & 115 & COMPUTATION FACILITY BLDG & 57 & 17,140 \\
\hline MAIN SITE & 116 & G.S & 53 & 7,781 \\
\hline MAIN SITE & 117 & COMPUTATION FACILITY BLDG & 58 & 11,370 \\
\hline MAIN SITE & 118 & TELECONFERENCE FACILITY & 24 & 1,505 \\
\hline MAIN SITE & 121 & PLS OFFICE & 56 & 90,759 \\
\hline MAIN SITE & 122 & PROTOCOL OFFICE & 42 & 962 \\
\hline MAIN SITE & 123 & AUDITORIUM & 53 & 7,742 \\
\hline MAIN SITE & 125 & WEST CAFETERIA & 52 & 12,513 \\
\hline MAIN SITE & 1277 & VACANT & 26 & 4,117 \\
\hline MAIN SITE & 1280 & VACANT & 17 & 5,760 \\
\hline MAIN SITE & 131 & ENGINEERING & 52 & 285,308 \\
\hline MAIN SITE & $132 \mathrm{~N}$ & DPRF & 16 & 251,316 \\
\hline MAIN SITE & $132 S$ & G.S & 17 & 219,385 \\
\hline MAIN SITE & 133 & CENTRAL PLANT/DPRF/NTTC & 17 & 5,631 \\
\hline MAIN SITE & 134 & G.S/STORAGE & 16 & 1,284 \\
\hline MAIN SITE & 135 & G.S/STORAGE & 16 & 1,369 \\
\hline MAIN SITE & 140 & G.S & 8 & 66,660 \\
\hline MAIN SITE & 141 & ELECTRONIC SHOPS & 57 & 47,342 \\
\hline MAIN SITE & 142 & PLS OFFICE & 7 & 20,306 \\
\hline MAIN SITE & 151 & ISOTOPE SCIENCES FACILITY & 43 & 96,030 \\
\hline MAIN SITE & 152 & GENERATOR HOUSE & 34 & 751 \\
\hline MAIN SITE & 153 & MICROFABRICATION LAB & 22 & 25,976 \\
\hline MAIN SITE & 154 & BIO SECURITY \& NANOSCIENCES LAB & 21 & 9,450 \\
\hline MAIN SITE & 155 & ISF OFFICE & 8 & 21,742 \\
\hline SITE 300 & $15 \mathrm{AL}$ & SITEWIDE ACCELERATORS & 32 & \\
\hline SITE 300 & 15CASC & CONPRD AIR SYS COMPRESS & & \\
\hline SITE 300 & $15 \mathrm{CSL}$ & COMM SYSTEM LINES & & \\
\hline SITE 300 & $15 \mathrm{CW}$ & WATER SYS POTBL DIST & & \\
\hline
\end{tabular}




\begin{tabular}{|c|c|c|c|c|}
\hline SITE 300 & 15EDT & ELECT DIST TRANSFORMERS & & \\
\hline SITE 300 & 15EGV & UTILITY ELEC GENERATORS & & \\
\hline SITE 300 & 15EPL & UTIL PRI ELEC DIST LINES & & \\
\hline SITE 300 & 15EPT & ELEC POWER TRANSFORMERS & & \\
\hline SITE 300 & 15ESL & UTIL ELEC SEC DIST LINES & & \\
\hline SITE 300 & 15FAS & FIRE ALARM SYSTEM & & \\
\hline SITE 300 & $15 F N C$ & ALL OTHER FENCES & & \\
\hline SITE 300 & 15GDS & GAS DIST SYSTEM & & \\
\hline SITE 300 & $15 \mathrm{HS}$ & HEATING SYS / BOILERS / OIL & & \\
\hline SITE 300 & 15LGS & UTIL ELEC SUBSTATIONS & & \\
\hline SITE 300 & 15LS & LANDSCAPING & & \\
\hline SITE 300 & 15RW & RETAINING WALL & & \\
\hline SITE 300 & 15RWPA & ROADS WALKS PAVED AREAS & & \\
\hline SITE 300 & 15SAS & SECURITY ALARM SYSTEM & & \\
\hline SITE 300 & $15 \mathrm{SCL}$ & ALL OTHER SECURITY LIGHTGS & & \\
\hline SITE 300 & 15SCSG & SEWAGE COLL SYS GRAVITY & & \\
\hline SITE 300 & 15SOT & STORAGE OIL TANK & & \\
\hline SITE 300 & 15SPS & SEWAGE POND / SEPTIC \& RETN TKS & & \\
\hline SITE 300 & $15 S T L$ & ALL OTHER STREET LIGHTING & & \\
\hline SITE 300 & 15WST & WATER STORAGE TANKS - 11 & 52 & \\
\hline MAIN SITE & 1601 & VACANT & 34 & 2,199 \\
\hline MAIN SITE & 1602 & VACANT & 32 & 2,160 \\
\hline MAIN SITE & 161 & JUPITER LASER SUPPORT & 34 & 6,105 \\
\hline MAIN SITE & 162 & RESEARCH/CRYSTAL GTH & 51 & 19,042 \\
\hline MAIN SITE & 1631 & VACANT & 24 & 1,443 \\
\hline MAIN SITE & 1632 & VACANT & 17 & 4,297 \\
\hline MAIN SITE & 164 & MACHINE SHOP & 24 & 207 \\
\hline MAIN SITE & 165 & OPTICS/DEVELOPMENT LAB & 53 & 10,053 \\
\hline MAIN SITE & 166 & DEVELOPMENT LAB & 51 & 13,226 \\
\hline MAIN SITE & 1677 & IMF MANAGED OFFICE FACILITY & 19 & 28,576 \\
\hline MAIN SITE & 1678 & VACANT & 18 & 3,550 \\
\hline MAIN SITE & 1680 & VACANT & 23 & 5,696 \\
\hline MAIN SITE & 170 & NARAC FACILITY & 16 & 43,760 \\
\hline MAIN SITE & $170 \mathrm{~A}$ & VACANT & 15 & 800 \\
\hline MAIN SITE & 1713 & TOILET TRAILER & 19 & 335 \\
\hline MAIN SITE & 1714 & SHOWER FACILITY & 12 & 270 \\
\hline MAIN SITE & 1726 & JUPITER SUPPORT & 32 & 2,160 \\
\hline MAIN SITE & 1727 & JUPITER TECH SUPPORT & 33 & 1,884 \\
\hline
\end{tabular}


Five-Year NRHP Re-Evaluation of Historic Building Assessment

\begin{tabular}{|c|c|c|c|c|}
\hline MAIN SITE & 173 & PLS WELD SHOP & 54 & 413 \\
\hline MAIN SITE & 1730 & JUPITER VISITORS & 30 & 2,100 \\
\hline MAIN SITE & 1735 & JUPITER MAIN OFFICE & 27 & 3,279 \\
\hline MAIN SITE & 1736 & SECURITY TRAINING & 26 & 4,591 \\
\hline MAIN SITE & 1739 & JUPITER OFFICES & 22 & 5,646 \\
\hline MAIN SITE & 174 & PLS & 54 & 19,437 \\
\hline MAIN SITE & 175 & IMF MANAGED LAB & 31 & 16,656 \\
\hline MAIN SITE & 176 & PLS SHOP & 54 & 3,973 \\
\hline MAIN SITE & 179 & PLS & 27 & 2,720 \\
\hline MAIN SITE & 1802 & TOILET TRAILER & 12 & 411 \\
\hline MAIN SITE & 181 & PLS & 22 & 13,532 \\
\hline MAIN SITE & 182 & VACANT & 29 & 2,027 \\
\hline MAIN SITE & 1826 & VACANT & 33 & 3,632 \\
\hline MAIN SITE & 1878 & VACANT & 29 & 6,292 \\
\hline MAIN SITE & 1879 & LABORATORY TRAINING CNTR & 25 & 11,118 \\
\hline MAIN SITE & 1884 & VACANT & 19 & 2,880 \\
\hline MAIN SITE & 1885 & VACANT & 19 & 4,210 \\
\hline MAIN SITE & 1886 & VACANT & 19 & 3,643 \\
\hline MAIN SITE & 1887 & VACANT & 19 & 5,089 \\
\hline MAIN SITE & 1888 & VACANT & 19 & 11,520 \\
\hline MAIN SITE & 1889 & LABORATORY TRAINING CENTER & 19 & 16,821 \\
\hline MAIN SITE & 190 & CAMS FACILITY & 24 & 10,252 \\
\hline MAIN SITE & 191 & HEAF & 22 & 121,028 \\
\hline MAIN SITE & 1925 & PLS OFFICE & 26 & 2,236 \\
\hline MAIN SITE & 1927 & VACANT & 28 & 2,160 \\
\hline MAIN SITE & $193 A$ & EPD/ORAD SRVC-MNTRNG STAT & 13 & 151 \\
\hline MAIN SITE & 194 & PLS & 53 & 41,543 \\
\hline MAIN SITE & $194 \mathrm{~A}$ & VACANT & 31 & 240 \\
\hline MAIN SITE & 195 & EPD/ORAD SHOP & 41 & 400 \\
\hline MAIN SITE & 196 & EPD/ORAD SRVC-MNTRNG STAT & 30 & 853 \\
\hline MAIN SITE & $196 A$ & EPD/ORAD STORAGE & 17 & 112 \\
\hline MAIN SITE & 197 & PLS LAB FACILITY & 27 & 10,716 \\
\hline MAIN SITE & 198 & MACHINE SHOP & 26 & 959 \\
\hline MAIN SITE & 211 & PLS & 13 & 14,122 \\
\hline MAIN SITE & 212 & VACANT & 59 & 3,770 \\
\hline MAIN SITE & 214 & VACANT & 57 & 4,837 \\
\hline MAIN SITE & 216 & CYBER SECURITY & 59 & 18,976 \\
\hline MAIN SITE & 217 & VACANT & 59 & 17,999 \\
\hline
\end{tabular}


Five-Year NRHP Re-Evaluation of Historic Building Assessment

\begin{tabular}{|c|c|c|c|c|}
\hline MAIN SITE & 218 & VACANT & 59 & 17,956 \\
\hline MAIN SITE & 2180 & VACANT & 15 & 1,764 \\
\hline MAIN SITE & 219 & IMF MANAGED OFFICE FACILITY & 59 & 18,429 \\
\hline MAIN SITE & 221 & VACANT & 40 & 1,764 \\
\hline MAIN SITE & 231 & DEVLMT \& ASSBLY ENGNG & 57 & 142,403 \\
\hline MAIN SITE & $231 \mathrm{~A}$ & BEAD BLASTER-RECEIVING & 7 & 110 \\
\hline MAIN SITE & 233 & MATERIALS MANAGEMENT & 51 & 4,933 \\
\hline MAIN SITE & 234 & MATERIALS MGMT OFFICE & 16 & 5,261 \\
\hline MAIN SITE & 235 & WMRDF & 24 & 88,175 \\
\hline MAIN SITE & 239 & RADIOGRAPHY & 42 & 12,904 \\
\hline MAIN SITE & 241 & VACANT & 51 & 54,369 \\
\hline MAIN SITE & 242 & OFFICE & 7 & 20,328 \\
\hline MAIN SITE & 243 & VACANT & 52 & 20,000 \\
\hline MAIN SITE & 251 & VACANT & 55 & 31,128 \\
\hline MAIN SITE & 2512 & VACANT & 18 & 360 \\
\hline MAIN SITE & 252 & HC/SHIPNG/RECEIVNG SHED & 18 & 191 \\
\hline MAIN SITE & 2525 & VACANT & 30 & 2,160 \\
\hline MAIN SITE & 253 & HC DEPT OFFICES \& LABS & 52 & 30,932 \\
\hline MAIN SITE & 254 & HC BIO ASSAY LAB & 51 & 2,488 \\
\hline MAIN SITE & 255 & HC SPD LABS-OFFICES & 42 & 21,855 \\
\hline MAIN SITE & 2552 & VACANT & 19 & 2,100 \\
\hline MAIN SITE & 2554 & VACANT & 26 & 740 \\
\hline MAIN SITE & 256 & TELCOM NODE \#1 & 26 & 5,937 \\
\hline MAIN SITE & 2580 & SECURE COMMUNICATION CENTER & 19 & 4,296 \\
\hline MAIN SITE & 261 & VACANT & 57 & 52,655 \\
\hline MAIN SITE & 262 & G.S & 53 & 10,882 \\
\hline MAIN SITE & 2625 & VACANT & 18 & 240 \\
\hline MAIN SITE & 2627 & VACANT & 25 & 1,867 \\
\hline MAIN SITE & 263 & VACANT & 21 & 51 \\
\hline MAIN SITE & 2632 & SECURITY & 16 & 2,817 \\
\hline MAIN SITE & 264 & ESH OFFICES & 6 & 20,461 \\
\hline MAIN SITE & 2679 & VACANT & 23 & 12,310 \\
\hline MAIN SITE & 2684 & VACANT & 22 & 5,284 \\
\hline MAIN SITE & 2685 & VACANT & 23 & 4,320 \\
\hline MAIN SITE & 2687 & VACANT & 23 & 2,100 \\
\hline MAIN SITE & 2701 & SECURITY SHOWER TRAILER & 26 & 696 \\
\hline MAIN SITE & 271 & PROTECTIVE FORCE & 38 & 18,874 \\
\hline MAIN SITE & 272 & PLS & 29 & 10,124 \\
\hline
\end{tabular}


Five-Year NRHP Re-Evaluation of Historic Building Assessment

\begin{tabular}{|c|c|c|c|c|}
\hline MAIN SITE & 2726 & OFFICE & 27 & 2,098 \\
\hline MAIN SITE & 2727 & LOCKS AND KEYS & 22 & 5,090 \\
\hline MAIN SITE & 2728 & VACANT & 29 & 2,160 \\
\hline MAIN SITE & 274 & SECURITY ADMINISTRATION & 17 & 21,436 \\
\hline MAIN SITE & 2775 & SECURITY & 33 & 9,875 \\
\hline MAIN SITE & 2777 & SECURITY ARMORY & 30 & 1,391 \\
\hline MAIN SITE & 2787 & SECURITY FITNESS FACILITY & 22 & 2,114 \\
\hline MAIN SITE & 280 & VACANT & 55 & 5,469 \\
\hline MAIN SITE & 2801 & VACANT & 36 & 2,199 \\
\hline MAIN SITE & 2802 & VACANT & 36 & 2,160 \\
\hline MAIN SITE & 2808 & TOILET TRAILER & 43 & 242 \\
\hline MAIN SITE & 281 & LABORATORY & 55 & 18,505 \\
\hline MAIN SITE & 282 & PLS & 25 & 2,160 \\
\hline MAIN SITE & 2825 & OFFICE & 30 & 5,959 \\
\hline MAIN SITE & 292 & CAMS LAB FACILITY & 32 & 20,811 \\
\hline MAIN SITE & 2925 & VACANT & 29 & 4,917 \\
\hline MAIN SITE & 293 & CAMS LAB FACILITY & 30 & 800 \\
\hline MAIN SITE & 294 & CAMS LAB FACILITY & 27 & 970 \\
\hline MAIN SITE & 297 & PAPER DISPOSAL & 43 & 1,086 \\
\hline MAIN SITE & 297A & MUSD CLASS DOC DESTRUCTION & 43 & 335 \\
\hline MAIN SITE & 298 & TARGET FABRICATION & 29 & 47,986 \\
\hline MAIN SITE & 311 & DOE OFFICES & 45 & 40,951 \\
\hline MAIN SITE & 312 & IMF MANAGED FACILITY & 55 & 11,482 \\
\hline MAIN SITE & $312 \mathrm{~A}$ & VACANT & 25 & 107 \\
\hline MAIN SITE & 313 & REGIONAL DISPATCH CENTER & 49 & 4,352 \\
\hline MAIN SITE & 314 & DIR.OFF/QA & 59 & 13,238 \\
\hline MAIN SITE & 315 & ESH ENVIRONMENTAL PROT & 59 & 18,133 \\
\hline MAIN SITE & 316 & DIRECTORS OFFICE & 59 & 14,090 \\
\hline MAIN SITE & 317 & NETWORKING GROUP FACILITY & 44 & 1,426 \\
\hline MAIN SITE & 318 & POOL CHANGE ROOM & 59 & 6,112 \\
\hline MAIN SITE & 3180 & VACANT & 34 & 4,371 \\
\hline MAIN SITE & 319 & IMF MANAGED OFFICE FACILITY & 59 & 18,048 \\
\hline MAIN SITE & 3203 & MATERIAL FABRICATION DIV & 33 & 649 \\
\hline MAIN SITE & 3204 & VACANT & 33 & 649 \\
\hline MAIN SITE & $321 \mathrm{~A}$ & MATERIALS FAB SHOP & 56 & 59,515 \\
\hline MAIN SITE & 321B & MATERIALS FAB SHOP & 56 & 7,511 \\
\hline MAIN SITE & $321 C$ & MATERIALS FAB SHOP & 56 & 78,335 \\
\hline MAIN SITE & $321 D$ & EE FABRICATION & 56 & 2,106 \\
\hline
\end{tabular}


Five-Year NRHP Re-Evaluation of Historic Building Assessment

\begin{tabular}{|c|c|c|c|c|}
\hline MAIN SITE & $321 \mathrm{E}$ & MMED BOILER ROOM & 56 & 2,581 \\
\hline MAIN SITE & 322 & PLATING SHOP & 49 & 5,704 \\
\hline MAIN SITE & 3226 & VACANT & 29 & 3,077 \\
\hline MAIN SITE & $322 \mathrm{~A}$ & PLATING SHOP ANNEX & 49 & 340 \\
\hline MAIN SITE & 323 & EMERGENCY SERVICES / FIRE STATION\#1 & 52 & 18,555 \\
\hline MAIN SITE & 324 & EMERGENCY SERVICES / ALARMS OFFICE & 52 & 10,181 \\
\hline MAIN SITE & 326 & VACANT & 58 & 3,516 \\
\hline MAIN SITE & 327 & RADIOGRAPHY & 52 & 19,100 \\
\hline MAIN SITE & 329 & LASER WELD SHOP & 26 & 5,150 \\
\hline MAIN SITE & 3304 & TOILET TRAILER & 8 & 128 \\
\hline MAIN SITE & 331 & TRITIUM FACILITY & 52 & 30,484 \\
\hline MAIN SITE & 332 & PU FACILITY & 51 & 104,787 \\
\hline MAIN SITE & 334 & HETB & 26 & 10,668 \\
\hline MAIN SITE & 3340 & OFFICES & 9 & 2,160 \\
\hline MAIN SITE & 335 & SUPPORT FACILITY & 28 & 11,988 \\
\hline MAIN SITE & $335 \mathrm{~A}$ & EMRGCY RESPONSE FACILITY & 15 & 64 \\
\hline MAIN SITE & 335B & EMRGCY RESPONSE FACILITY & 15 & 64 \\
\hline MAIN SITE & 336 & SOUTH SECURITY PORTAL & 21 & 792 \\
\hline MAIN SITE & 337 & NW SECURITY PORTAL & 21 & 792 \\
\hline MAIN SITE & 341 & VACANT & 47 & 44,184 \\
\hline MAIN SITE & 3427 & VACANT & 19 & 6,365 \\
\hline MAIN SITE & 343 & IMF MANAGED OFFICE/LAB FACILITY & 51 & 27,368 \\
\hline MAIN SITE & 345 & VACANT & 48 & 9,467 \\
\hline MAIN SITE & 3526 & HUMAN RELIABILITY PROGRAM & 22 & 2,165 \\
\hline MAIN SITE & 3527 & DOE OFFICES & 17 & 9,782 \\
\hline MAIN SITE & 3555 & HUMAN RELIABILITY PROGRAM & 14 & 508 \\
\hline MAIN SITE & 3577 & VACANT & 22 & 4,290 \\
\hline MAIN SITE & 361 & BIOSCIENCES RESEARCH & 42 & 68,889 \\
\hline MAIN SITE & 362 & VACANT & 47 & 3,766 \\
\hline MAIN SITE & 363 & VACANT & 46 & 1,584 \\
\hline MAIN SITE & 364 & BIOSCIENCES RESEARCH & 42 & 10,932 \\
\hline MAIN SITE & 3649 & VACANT & 16 & 4,800 \\
\hline MAIN SITE & 365 & G.S/BIO LAB & 31 & 8,825 \\
\hline MAIN SITE & 366 & BIOSCIENCES RESEARCH & 29 & 2,631 \\
\hline MAIN SITE & 367 & VACANT & 25 & 629 \\
\hline MAIN SITE & 368 & G.S/BSL-3 LABORATORY & 6 & 1,590 \\
\hline MAIN SITE & 3724 & COMPUTATION FACILITY BLDG & 35 & 19,810 \\
\hline MAIN SITE & 3725 & NIF DIRECTORATE OFFICES & 35 & 19,867 \\
\hline
\end{tabular}


Five-Year NRHP Re-Evaluation of Historic Building Assessment

\begin{tabular}{|c|c|c|c|c|}
\hline MAIN SITE & 3726 & NIF DIRECTORATE OFFICES & 35 & 19,824 \\
\hline MAIN SITE & 373 & BIO WAREHOUSE & 18 & 1,768 \\
\hline MAIN SITE & 3751 & VACANT & 22 & 2,160 \\
\hline MAIN SITE & 376 & VACANT & 32 & 1,575 \\
\hline MAIN SITE & 3775 & VACANT & 18 & 1,440 \\
\hline MAIN SITE & 378 & LAB SPACE & 29 & 3,840 \\
\hline MAIN SITE & 379 & LAB SPACE & 27 & 1,500 \\
\hline MAIN SITE & 381 & OFFICE/RESEARCH & 36 & 95,421 \\
\hline MAIN SITE & 382 & TECH SUPPORT & 34 & 303 \\
\hline MAIN SITE & 383 & MACHINE SHOP & 29 & 6,715 \\
\hline MAIN SITE & 391 & DEVELOPMENT LABS & 33 & 197,841 \\
\hline MAIN SITE & 392 & OPTICS LABORATORY & 26 & 8,413 \\
\hline MAIN SITE & 3925 & REDWOOD RM.-CONF./CLASSROOM & 31 & 1,081 \\
\hline MAIN SITE & 3982 & VACANT & 22 & 1,800 \\
\hline MAIN SITE & 404 & MUSD / BATTERY SHOP / WAREHOUSE & 59 & 6,460 \\
\hline MAIN SITE & 405 & VACANT & 59 & 8,636 \\
\hline MAIN SITE & 406 & VACANT & 32 & 449 \\
\hline MAIN SITE & 4107 & VACANT & 26 & 388 \\
\hline MAIN SITE & 411 & SHIPPING/RECEIVING & 55 & 71,625 \\
\hline MAIN SITE & 4113 & PAINT SHOP STORAGE & 22 & 183 \\
\hline MAIN SITE & 415 & EMPLOYEE RESOURCES & 59 & 19,297 \\
\hline MAIN SITE & 418 & MUSD PAINT SHOP & 53 & 12,167 \\
\hline MAIN SITE & 423 & BEAM RESEARCH MACHINE SHOP & 58 & 7,791 \\
\hline MAIN SITE & 4302 & ERD OFFICES & 34 & 5,022 \\
\hline MAIN SITE & 431 & BEAM RESEARCH CENTER & 58 & 54,545 \\
\hline MAIN SITE & 4316 & VACANT & 46 & 299 \\
\hline MAIN SITE & 432 & IMF MANAGED LAB FACILITY & 47 & 33,575 \\
\hline MAIN SITE & 433 & LABOR ONLY METAL SHOP & 28 & 5,793 \\
\hline MAIN SITE & 435 & VACANT & 51 & 57,724 \\
\hline MAIN SITE & 4352 & ERD OFC-FIELD OPERATIONS & 9 & 241 \\
\hline MAIN SITE & 436 & PLS SHIPPING/RECEIVING/STORAGE & 55 & 9,745 \\
\hline MAIN SITE & 4377 & ERD OFFICES & 34 & 4,920 \\
\hline MAIN SITE & 4378 & ERD OFFICES & 23 & 5,180 \\
\hline MAIN SITE & 438 & ERD OFC-FIELD OPERATIONS & 31 & 16,262 \\
\hline MAIN SITE & 4382 & VACANT & 19 & 3,583 \\
\hline MAIN SITE & 4383 & VACANT & 22 & 4,988 \\
\hline MAIN SITE & 4384 & VACANT & 22 & 1,577 \\
\hline MAIN SITE & 4385 & VACANT & 22 & 3,744 \\
\hline
\end{tabular}


Five-Year NRHP Re-Evaluation of Historic Building Assessment

\begin{tabular}{|c|c|c|c|c|}
\hline MAIN SITE & 4387 & VACANT & 22 & 3,658 \\
\hline MAIN SITE & 4388 & VACANT & 22 & 320 \\
\hline MAIN SITE & 439 & INSTITUTIONAL COMPUTING/ARCHIVES & 31 & 12,055 \\
\hline MAIN SITE & 4406 & VACANT & 36 & 1,560 \\
\hline MAIN SITE & 442 & ERD / D\&D OPERATIONS & 48 & 4,169 \\
\hline MAIN SITE & 443 & VACANT & 50 & 8,953 \\
\hline MAIN SITE & 444 & VACANT & 55 & 805 \\
\hline MAIN SITE & 445 & VACANT & 29 & 5,100 \\
\hline MAIN SITE & 446 & VACANT & 51 & 1,743 \\
\hline MAIN SITE & 4475 & VACANT & 28 & 4,176 \\
\hline MAIN SITE & 451 & COMPUTATION FACILITY BLDG & 31 & 51,398 \\
\hline MAIN SITE & 452 & COMPUTATION FACILITY BLDG. & 27 & 492 \\
\hline MAIN SITE & 4525 & COMPUTATION FACILITY BLDG & 26 & 5,736 \\
\hline MAIN SITE & 453 & TERA SCALE FACILITY & 7 & 240,598 \\
\hline MAIN SITE & 4576 & COMPUTATION FACILITY BLDG & 18 & 854 \\
\hline MAIN SITE & 4675 & EMPLOYEE RESOURCES & 32 & 11,142 \\
\hline MAIN SITE & 471 & CENTRAL CAFETERIA & 7 & 16,086 \\
\hline MAIN SITE & 4725 & VACANT & 18 & 9,389 \\
\hline MAIN SITE & 4726 & S\&T / COMP & 18 & 9,384 \\
\hline MAIN SITE & 4727 & O\&B TID LIBRARY & 18 & 9,891 \\
\hline MAIN SITE & 4728 & COMPUTATIONS & 18 & 6,762 \\
\hline MAIN SITE & 4729 & O\&B TID LIBRARY & 18 & 10,018 \\
\hline MAIN SITE & 473 & VACANT & 23 & 205 \\
\hline MAIN SITE & 481 & OFFICE & 29 & 61,253 \\
\hline MAIN SITE & 482 & OFFICE & 28 & 108,000 \\
\hline MAIN SITE & 490 & IMF MANAGED LAB FACILITY & 28 & 216,789 \\
\hline MAIN SITE & 4905 & VACANT & 41 & 323 \\
\hline MAIN SITE & 4906 & VACANT & 41 & 323 \\
\hline MAIN SITE & 491 & VACANT & 27 & 13,259 \\
\hline MAIN SITE & 492 & VACANT & 27 & 9,550 \\
\hline MAIN SITE & 4924 & VACANT & 8 & 665 \\
\hline MAIN SITE & 4926 & VACANT & 34 & 1,641 \\
\hline MAIN SITE & 493 & SUPPORT FACILITY/STORAGE & 24 & 19,100 \\
\hline MAIN SITE & 494 & STORAGE & 22 & 29,961 \\
\hline MAIN SITE & 501 & DUS OFFICE & 11 & 200 \\
\hline MAIN SITE & 509 & MUSD SHEET MTL SHOP STO & 33 & 256 \\
\hline MAIN SITE & 510 & MUSD / FACS / UPS BATTERY BANK & 27 & 144 \\
\hline MAIN SITE & 5104 & INDUSTRIAL GAS FACILITY & 33 & 624 \\
\hline
\end{tabular}


Five-Year NRHP Re-Evaluation of Historic Building Assessment November 2011 LLNL - Main Site and Site 300

\begin{tabular}{|c|c|c|c|c|}
\hline MAIN SITE & 5105 & LABOR ONLY CONSTRUCTION & 46 & 627 \\
\hline MAIN SITE & 511 & MUSD / CRAFTS SHOP & 59 & 77,078 \\
\hline MAIN SITE & 512 & MUSD / CRAFTS SUPPLIES & 47 & 8,128 \\
\hline MAIN SITE & 5125 & LABOR ONLY CONSTRUCTION OFFICE & 36 & 2,590 \\
\hline MAIN SITE & $514 \mathrm{~A}$ & VACANT & 22 & 2,530 \\
\hline MAIN SITE & 515 & MUSD / CRAFTS STORAGE & 45 & 8,497 \\
\hline MAIN SITE & 516 & PE/CRAFTS FACILITY/ME & 59 & 6,496 \\
\hline MAIN SITE & 517 & ELECT UTILITY OFFICES & 59 & 6,090 \\
\hline MAIN SITE & $517 A$ & MUSD / CUSTODIAN LAUNDRY RM & 26 & 474 \\
\hline MAIN SITE & $518 \mathrm{~A}$ & INDUSTRIAL GAS STORAGE & 18 & 204 \\
\hline MAIN SITE & 519 & MUSD / HEAVY EQUIPMENT REPAIR & 58 & 9,788 \\
\hline MAIN SITE & $519 \mathrm{~A}$ & HEAVY EQUIPMENT STORAGE & 55 & 594 \\
\hline MAIN SITE & 520 & MUSD / PESTICIDE STORAGE & 44 & 400 \\
\hline MAIN SITE & 5207 & VACANT & 41 & 320 \\
\hline MAIN SITE & 522 & LABOR ONLY RESTROOM FACILITY & 22 & 515 \\
\hline MAIN SITE & 5225 & LABOR ONLY CONSTRUCTION OFFICE & 33 & 1,939 \\
\hline MAIN SITE & 5226 & VACANT & 34 & 2,548 \\
\hline MAIN SITE & 523 & LABOR ONLY / WELD / CARPTRY WK SHED & 26 & 4,064 \\
\hline MAIN SITE & 525 & LABOR ONLY ELECT & 20 & 1,632 \\
\hline MAIN SITE & 531 & ICS OFFICE & 28 & 12,381 \\
\hline MAIN SITE & 532 & EPD/ORAD SERVICE BLDG & 18 & 198 \\
\hline MAIN SITE & 533 & EPD/DO STORAGE & 27 & 320 \\
\hline MAIN SITE & 5425 & VACANT & 23 & 5,256 \\
\hline MAIN SITE & 5426 & VACANT & 23 & 5,256 \\
\hline MAIN SITE & 543 & O\&B / PFS / SHMR OFFICES & 30 & 78,261 \\
\hline MAIN SITE & 5475 & ICS DEPT OFFICE & 27 & 32,368 \\
\hline MAIN SITE & 5477 & IMF MANAGED OFFICE FACILITY & 18 & 6,693 \\
\hline MAIN SITE & $551 \mathrm{E}$ & O\&B / F\&I OFFICES & 29 & 40,966 \\
\hline MAIN SITE & $551 \mathrm{~W}$ & $\mathrm{BUS} / \mathrm{NCOP} / \mathrm{TID} / \mathrm{SCM}$ & 29 & 65,776 \\
\hline MAIN SITE & 5626 & AUDIT \& OVERSIGHT & 18 & 4,356 \\
\hline MAIN SITE & 5627 & LEGAL SERVICES & 26 & 8,470 \\
\hline MAIN SITE & 5675 & STAFF RELATIONS & 8 & 4,277 \\
\hline MAIN SITE & 571 & NIF OFFICE & 26 & 41,407 \\
\hline MAIN SITE & 581 & THE NATIONAL IGNITION FACILITY & 9 & 696,968 \\
\hline MAIN SITE & 582 & SERVICE BUILDING & 11 & 2,927 \\
\hline MAIN SITE & 583 & OFFICE & 5 & 21,793 \\
\hline MAIN SITE & 591 & NIF STORAGE & 19 & 3,207 \\
\hline MAIN SITE & 597 & ERD CORP YARD & 25 & 300 \\
\hline
\end{tabular}


Five-Year NRHP Re-Evaluation of Historic Building Assessment November 2011 LLNL - Main Site and Site 300

\begin{tabular}{|c|c|c|c|c|}
\hline MAIN SITE & $597 A$ & ERD RESTRM \& SHWR FAC & 19 & 99 \\
\hline MAIN SITE & 610 & TRUCK INSPECTION STATION & 7 & 4,281 \\
\hline MAIN SITE & 611 & AUTO FLEET MAINTENANCE & 36 & 15,018 \\
\hline MAIN SITE & 612 & EPD/RHWM WASTE TSDF & 45 & 7,015 \\
\hline MAIN SITE & 6127 & EPD/RHWM OFFICE & 18 & 1,560 \\
\hline MAIN SITE & $612 \mathrm{~A}$ & EPD/RHWM WASTE TSDF & 22 & 4,181 \\
\hline MAIN SITE & 614 & EPD/RHWM WASTE TSDF & 45 & 1,221 \\
\hline MAIN SITE & 615 & DUS OFFICE & 33 & 3,525 \\
\hline MAIN SITE & 616 & VACANT & 33 & 2,273 \\
\hline MAIN SITE & 6178 & EPD/RHWM OFF/CHANGE HOUSE & 35 & 1,040 \\
\hline MAIN SITE & 6179 & EPD/RHWM OFFICE & 26 & 3,904 \\
\hline MAIN SITE & 619 & DONATION UTIL\&SALES & 32 & 2,038 \\
\hline MAIN SITE & 6205 & MUSD HEAVY EQUIP. STORAGE & 19 & 404 \\
\hline MAIN SITE & 6206 & IE STORAGE & 18 & 688 \\
\hline MAIN SITE & 622 & F\&I CORP. YARD & 43 & 1,033 \\
\hline MAIN SITE & 624 & EPD/RHWM OFFICE & 31 & 240 \\
\hline MAIN SITE & 625 & EPD/RHWM WASTE TSDF & 29 & 4,854 \\
\hline MAIN SITE & 6301 & RIGGER STORAGE & 7 & 732 \\
\hline MAIN SITE & 6325 & VACANT & 17 & 4,320 \\
\hline MAIN SITE & 6424 & VACANT & 8 & 390 \\
\hline MAIN SITE & 6426 & VACANT & 30 & 2,100 \\
\hline MAIN SITE & 6475 & $\begin{array}{l}\text { HIGH PERFORMANCE COMPUTING } \\
\text { INNOVATION CENTER }\end{array}$ & 0 & 12,070 \\
\hline MAIN SITE & 6501 & PUBLIC AFFAIRS OFFICE & 22 & 908 \\
\hline MAIN SITE & 651 & VISITOR CENTER & 35 & 2,381 \\
\hline MAIN SITE & 652 & PUBLIC AFFAIRS STORAGE & 35 & 208 \\
\hline MAIN SITE & 6525 & VISITORS CTR AUDITRM & 35 & 971 \\
\hline MAIN SITE & 6526 & PUBLIC AFFAIRS OFFICE & 35 & 2,756 \\
\hline MAIN SITE & 6527 & VACANT & 18 & 2,115 \\
\hline MAIN SITE & 653 & EPD SAMPLE STAGING & 6 & 96 \\
\hline MAIN SITE & 6575 & PUBLIC AFFAIRS OFFICE & 22 & 1,460 \\
\hline MAIN SITE & 663 & HEALTH SERVICES & 23 & 24,786 \\
\hline MAIN SITE & 671 & PROCUREMENT & 26 & 41,476 \\
\hline MAIN SITE & 681 & OPTICS ASSEMBLY BLDG & 11 & 46,819 \\
\hline MAIN SITE & 684 & CHEMICAL STORAGE & 11 & 278 \\
\hline MAIN SITE & 6870 & OFFICE & 18 & 1,444 \\
\hline MAIN SITE & 6901 & TOILET TRAILER & 43 & 520 \\
\hline MAIN SITE & 691 & IMF MANAGED LAB FACILITY & 29 & 18,437 \\
\hline
\end{tabular}


Five-Year NRHP Re-Evaluation of Historic Building Assessment November 2011 LLNL - Main Site and Site 300

\begin{tabular}{|c|c|c|c|c|}
\hline MAIN SITE & 6925 & IMF MANAGED OFFICE FACILITY & 22 & 5,873 \\
\hline MAIN SITE & 6926 & IMF MANAGED OFFICE FACILITY & 20 & 2,160 \\
\hline MAIN SITE & 6928 & IMF MANAGED OFFICE FACILITY & 22 & 1,912 \\
\hline MAIN SITE & 6929 & NIF OFFICE TRAILER & 6 & 4,925 \\
\hline MAIN SITE & 693 & EPD/RHWM WASTE STORAGE & 24 & 12,000 \\
\hline MAIN SITE & 6930 & NIF OFFICE TRAILER & 6 & 5,937 \\
\hline MAIN SITE & 6931 & NIF CONSTRUCTION BREAKROOM & 2 & 1,405 \\
\hline MAIN SITE & 694 & EPD/RHWM OFFICE & 14 & 10,590 \\
\hline MAIN SITE & 695 & EPD/RHWM LIQUID WST PROCSSING & 12 & 46,504 \\
\hline MAIN SITE & 6951 & EPD/RHWM SERVICE BUILDING & 31 & 1,440 \\
\hline MAIN SITE & 696 & EPD/RHWM WST PRCSSING-SOLID & 13 & 21,381 \\
\hline MAIN SITE & 697 & EPD/RHWM WRHS-CHEM EXCHG & 13 & 4,118 \\
\hline MAIN SITE & 6989 & TOILET TRAILER & 8 & 720 \\
\hline OFF SITE & 7990 & DINE COLLEGE OFFICES & 13 & 850 \\
\hline SITE 300 & $801 \mathrm{~A}$ & FIRING FACILITY(FXR) & 29 & 44,262 \\
\hline SITE 300 & 801B & TECHNICAL MAINTENANCE SHOP & 43 & 790 \\
\hline SITE 300 & 801D & ADMINISTRATION & 17 & 4,686 \\
\hline SITE 300 & $802 \mathrm{~A}$ & VACANT & 56 & 3,264 \\
\hline SITE 300 & 803 & EPD/ORAD STRG WRHS & 54 & 1,719 \\
\hline SITE 300 & 804 & STAGING AREA & 53 & 107 \\
\hline SITE 300 & 805 & INERT MACHNG/EXPLVS WST PACKNG & 54 & 6,830 \\
\hline SITE 300 & $806 \mathrm{~A}$ & HE MACHINING & 54 & 3,417 \\
\hline SITE 300 & $806 \mathrm{~B}$ & HE MACHINING & 54 & 4,088 \\
\hline SITE 300 & $806 C$ & MACHINING STORAGE & 54 & 640 \\
\hline SITE 300 & $806 \mathrm{D}$ & MACHINING STORAGE & 52 & 192 \\
\hline SITE 300 & 807 & HE MACHINING & 51 & 1,575 \\
\hline SITE 300 & $809 \mathrm{~A}$ & HE PRESSING & 52 & 2,570 \\
\hline SITE 300 & $809 \mathrm{~B}$ & MECHANICAL SUPPORT & 8 & 617 \\
\hline SITE 300 & $809 C$ & HE OVEN FACILITY & 47 & 606 \\
\hline SITE 300 & $810 \mathrm{~A}$ & HE ASSEMBLY & 39 & 3,365 \\
\hline SITE 300 & $810 \mathrm{~B}$ & HE ASSEMBLY & 29 & 921 \\
\hline SITE 300 & $810 C$ & ASSEMBLY STORAGE & 29 & 914 \\
\hline SITE 300 & 811 & VACANT & 52 & 1,081 \\
\hline SITE 300 & $812 \mathrm{~A}$ & VACANT & 51 & 2,656 \\
\hline SITE 300 & $812 \mathrm{D}$ & VACANT & 40 & 325 \\
\hline SITE 300 & $812 \mathrm{E}$ & LABORATORY & 40 & 1,310 \\
\hline SITE 300 & 813 & CHANGE HOUSE & 54 & 2,870 \\
\hline SITE 300 & 816 & EXPLSE WASTE STRG FAC & 14 & 1,223 \\
\hline
\end{tabular}


Five-Year NRHP Re-Evaluation of Historic Building Assessment

\begin{tabular}{|c|c|c|c|c|}
\hline SITE 300 & $817 \mathrm{~A}$ & HE PRESSING CONTROL ROOM & 54 & 417 \\
\hline SITE 300 & 817B & HE PRESSING CELL & 54 & 639 \\
\hline SITE 300 & 817D & HE PRESSING STORAGE & 54 & 207 \\
\hline SITE 300 & $817 \mathrm{E}$ & HE PRESSING-INACTIVE & 35 & 186 \\
\hline SITE 300 & $817 \mathrm{~F}$ & HE PRESSING OVENS & 54 & 526 \\
\hline SITE 300 & $817 G$ & HE PRESSING BOILERS & 54 & 237 \\
\hline SITE 300 & $817 \mathrm{H}$ & HE PRESSING INERT STORAGE & 54 & 890 \\
\hline SITE 300 & $818 \mathrm{~A}$ & HE STORAGE FACILITY & 47 & 1,244 \\
\hline SITE 300 & $818 \mathrm{C}$ & HE STORAGE FACILITY & 39 & 578 \\
\hline SITE 300 & 819 & PE/STORAGE-C\&M SHOPS & 50 & 828 \\
\hline SITE 300 & 821 & CHEMISTRY STORAGE & 50 & 650 \\
\hline SITE 300 & $823 \mathrm{~A}$ & LINAC RADIOGRAPHY & 30 & 1,089 \\
\hline SITE 300 & $823 B$ & LINAC RADIOGRAPHY & 44 & 1,842 \\
\hline SITE 300 & 824 & HE STORAGE FACILITY & 35 & 300 \\
\hline SITE 300 & 825 & CHEM PROCESS FACILITY & 52 & 1,370 \\
\hline SITE 300 & 826 & CHEM PROCESS FACILITY & 50 & 1,638 \\
\hline SITE 300 & $827 \mathrm{~A}$ & CHEMISTRY BLDG & 43 & 4,539 \\
\hline SITE 300 & $827 B$ & SERVICE SHOP & 43 & 871 \\
\hline SITE 300 & $827 C$ & CHEM PROCESS FACILITY & 43 & 4,579 \\
\hline SITE 300 & 827D & CHEM PROCESS FACILITY & 43 & 4,579 \\
\hline SITE 300 & $827 \mathrm{E}$ & CHEM PROCESS FACILITY & 43 & 4,407 \\
\hline SITE 300 & $828 \mathrm{~A}$ & VACANT & 44 & 212 \\
\hline SITE 300 & $828 \mathrm{~B}$ & VACANT & 46 & 199 \\
\hline SITE 300 & $828 \mathrm{C}$ & VACANT & 47 & 258 \\
\hline SITE 300 & 830 & VACANT & 54 & 1,764 \\
\hline SITE 300 & $832 \mathrm{~A}$ & STORAGE & 54 & 540 \\
\hline SITE 300 & $832 \mathrm{C}$ & STORAGE & 54 & 335 \\
\hline SITE 300 & $832 \mathrm{E}$ & MM OFFICE/SHIP\&RECEIVE & 30 & 1,581 \\
\hline SITE 300 & 833 & EPD/ERD SERVICE-R\&D & 52 & 1,892 \\
\hline SITE 300 & 8340 & EPD/ERD SRVC-MNTRNG TF834 & 50 & 282 \\
\hline SITE 300 & $834 \mathrm{~A}$ & THERMAL TEST FACILITY & 51 & 1,694 \\
\hline SITE 300 & 834B & VACANT & 51 & 751 \\
\hline SITE 300 & $834 \mathrm{C}$ & VACANT & 51 & 751 \\
\hline SITE 300 & 834D & VACANT & 51 & 1,694 \\
\hline SITE 300 & $834 \mathrm{E}$ & VACANT & 51 & 998 \\
\hline SITE 300 & $834 \mathrm{~F}$ & VACANT & 51 & 649 \\
\hline SITE 300 & $834 G$ & VACANT & 51 & 527 \\
\hline SITE 300 & $834 \mathrm{H}$ & THERMAL TEST FACILITY & 51 & 998 \\
\hline
\end{tabular}


Five-Year NRHP Re-Evaluation of Historic Building Assessment

\begin{tabular}{|c|c|c|c|c|}
\hline SITE 300 & $834 \mathrm{~J}$ & VACANT & 42 & 511 \\
\hline SITE 300 & $834 K$ & PUMP STATION & 50 & 545 \\
\hline SITE 300 & $834 \mathrm{~L}$ & VACANT & 42 & 1,281 \\
\hline SITE 300 & 835 & EPD/ERD STORAGE & 50 & 1,216 \\
\hline SITE 300 & $836 \mathrm{~A}$ & DYNAMIC TEST FACILITY & 41 & 2,191 \\
\hline SITE 300 & $836 \mathrm{~B}$ & STORAGE FACILITY & 41 & 4,505 \\
\hline SITE 300 & $836 C$ & VACANT & 41 & 2,900 \\
\hline SITE 300 & 836D & DYNAMIC TEST FACILITY & 29 & 3,427 \\
\hline SITE 300 & 837 & STORAGE FACILITY & 44 & 1,031 \\
\hline SITE 300 & 841 & PE/STORAGE - C\&M SHOPS & 52 & 1,786 \\
\hline SITE 300 & $843 \mathrm{~A}$ & EPD/ERD CORP YARD & 25 & 486 \\
\hline SITE 300 & $843 B$ & VACANT & 25 & 402 \\
\hline SITE 300 & $845 \mathrm{~A}$ & EXPL WASTE TREATMNT FAC & 56 & 431 \\
\hline SITE 300 & $845 B$ & EWTF & 13 & 290 \\
\hline SITE 300 & 848 & VACANT & 27 & 1,300 \\
\hline SITE 300 & 850 & VACANT & 51 & 5,095 \\
\hline SITE 300 & $851 \mathrm{~A}$ & FIRING FACILITY & 51 & 12,996 \\
\hline SITE 300 & $851 \mathrm{~B}$ & MACHINE SHOP & 51 & 985 \\
\hline SITE 300 & $851 C$ & FABRICATION SHOP & 17 & 652 \\
\hline SITE 300 & $854 \mathrm{~A}$ & VACANT & 52 & 2,458 \\
\hline SITE 300 & $855 \mathrm{~A}$ & HE MACHINING & 52 & 667 \\
\hline SITE 300 & $855 B$ & HE MACHINING & 52 & 637 \\
\hline SITE 300 & $855 C$ & HE MACHINING & 50 & 612 \\
\hline SITE 300 & 856 & VACANT & 51 & 1,613 \\
\hline SITE 300 & 8580 & BREAKROOM TRAILER & 5 & 384 \\
\hline SITE 300 & 859 & STORAGE & 52 & 1,500 \\
\hline SITE 300 & 860 & STORAGE & 33 & 298 \\
\hline SITE 300 & 865 & VACANT & 29 & 61,360 \\
\hline SITE 300 & 867 & BUNKER SUPPORT FACILITY & 17 & 4,342 \\
\hline SITE 300 & 869 & $\mathrm{WCl}$ & 23 & 353 \\
\hline SITE 300 & 870 & OFFICE FACILITY & 53 & 4,000 \\
\hline SITE 300 & 871 & ADMINISTRATION & 53 & 7,928 \\
\hline SITE 300 & 872 & PE/PAINT SHOP & 56 & 1,887 \\
\hline SITE 300 & 8724 & VACANT & 8 & 322 \\
\hline SITE 300 & 8726 & EPD/ERD OFFICE & 19 & 953 \\
\hline SITE 300 & 873 & PE/C\&M SHOPS & 53 & 17,452 \\
\hline SITE 300 & 874 & MECHANICAL SHOPS & 52 & 19,972 \\
\hline SITE 300 & $874 \mathrm{~A}$ & VACANT & 31 & 279 \\
\hline
\end{tabular}


Five-Year NRHP Re-Evaluation of Historic Building Assessment

\begin{tabular}{|c|c|c|c|c|}
\hline SITE 300 & 874B & VACANT & 31 & 279 \\
\hline SITE 300 & 875 & PE/SUPPLY \& MAINTENANCE & 51 & 15,171 \\
\hline SITE 300 & 876 & STORES \& RECLAMATION & 51 & 2,400 \\
\hline SITE 300 & 877 & COMPUTER TECHL SUPPORT & 50 & 3,352 \\
\hline SITE 300 & 878 & PE/MAINT SHOP STORAGE & 49 & 488 \\
\hline SITE 300 & 879 & MOTOR POOL \& GARAGE & 41 & 2,879 \\
\hline SITE 300 & 880 & VACANT & 48 & 2,839 \\
\hline SITE 300 & 8806 & VACANT & 22 & 509 \\
\hline SITE 300 & 882 & PFD COMM CENTER & 22 & 4,912 \\
\hline SITE 300 & 8825 & SHOWER FACILITY & 14 & 370 \\
\hline SITE 300 & 8826 & SECURITY FITNESS & 14 & 943 \\
\hline SITE 300 & 886 & CHEMICAL STORAGE & 16 & 36 \\
\hline SITE 300 & 889 & SITE 300 MEDICAL FACILITY & 11 & 2,719 \\
\hline SITE 300 & 890 & SITE 300 FIRE STATION & 11 & 6,863 \\
\hline SITE 300 & 892 & CENTRAL CONTROL POST & 17 & 866 \\
\hline SITE 300 & 895 & EPD/ORAD OFFICE & 51 & 380 \\
\hline SITE 300 & 8990 & B899 A\&B WASH UP FACILITY & 17 & 281 \\
\hline SITE 300 & 8991 & INSTRUCTOR FACILITY & 12 & 480 \\
\hline SITE 300 & 899A & GUN SHOP & 40 & 572 \\
\hline SITE 300 & $899 B$ & PISTOL RANGE TRNING/OFFICE & 40 & 688 \\
\hline OFF SITE & 9997 & L ENFANT PLAZA & 14 & 5,274 \\
\hline OFF SITE & 9998 & THE AMERICAN RED CROSS & 4 & 5,682 \\
\hline MAIN SITE & CW01 & WATER SYS POT DISTRIBUTION & & \\
\hline MAIN SITE & CW02 & WATER SYS POT SUPPLY LINE & & \\
\hline MAIN SITE & CW03 & WATER SYS POT STA(ZONE7) & & \\
\hline MAIN SITE & CW06 & STORAGE WATER TANKS & & \\
\hline MAIN SITE & DW001 & WATER SYS DW TREAT PLTS & & \\
\hline MAIN SITE & DW002 & WATER SYS DW DIST & & \\
\hline MAIN SITE & LCW06 & CLG WATER SYS DISTRIBUTION & & \\
\hline MAIN SITE & OS012A & SECURITY KIOSK & 8 & \\
\hline MAIN SITE & OS012B & SECURITY KIOSK & 8 & \\
\hline MAIN SITE & OS012C & SECURITY KIOSK & 8 & \\
\hline MAIN SITE & OS041S & SECURITY KIOSK & 21 & \\
\hline MAIN SITE & OS071N & SECURITY KIOSK & 19 & \\
\hline MAIN SITE & OS113E & SECURITY KIOSK & 36 & \\
\hline MAIN SITE & OS122S & SECURITY KIOSK & 41 & \\
\hline MAIN SITE & OS122W & SECURITY KIOSK & 25 & \\
\hline MAIN SITE & OS169WAA & EPD/RHWM WASTE ACC AREA & 21 & \\
\hline
\end{tabular}




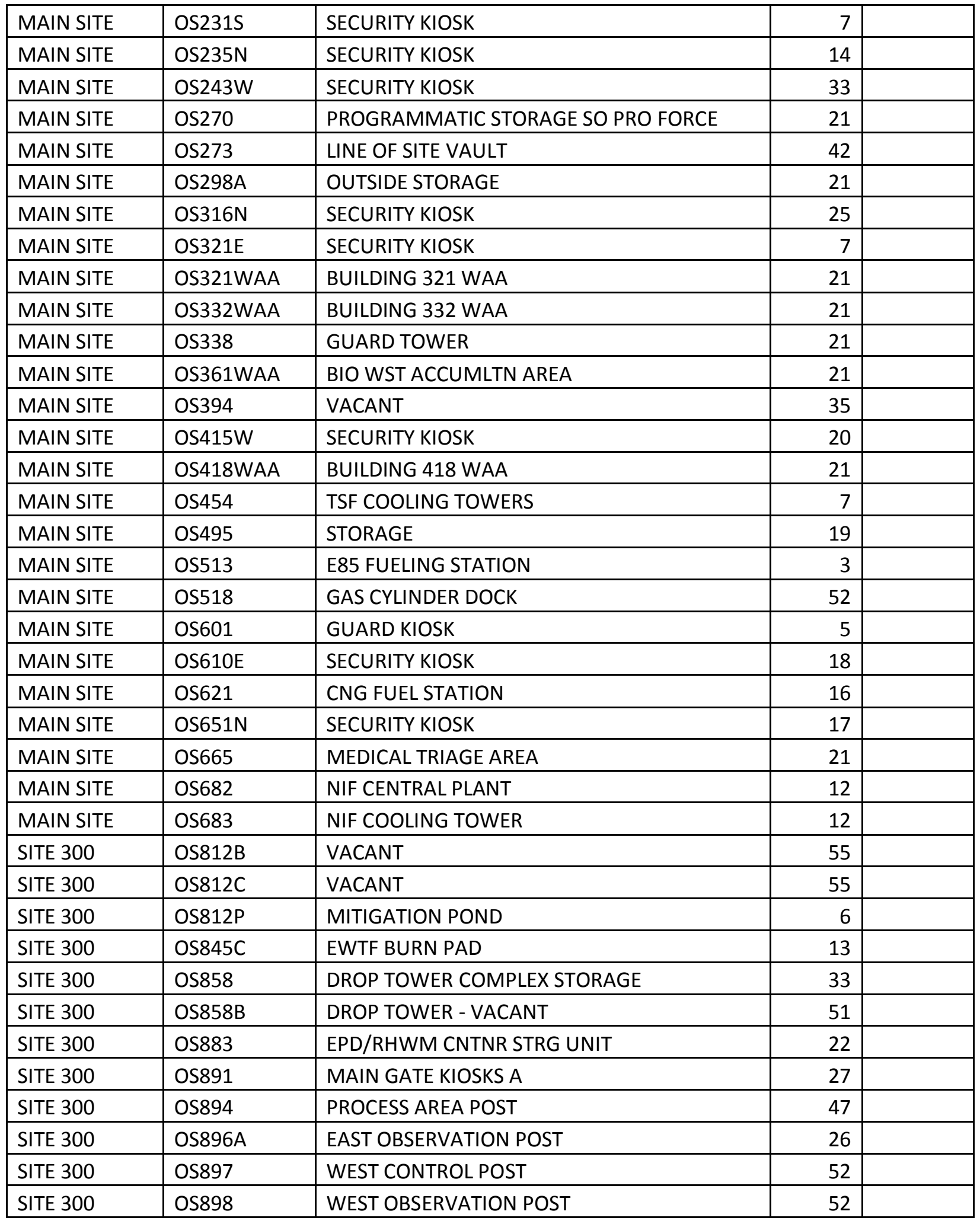




\begin{tabular}{|c|c|c|c|}
\hline SITE 300 & OS899 & PISTOL RANGE & 40 \\
\hline SITE 300 & OS899C & LIVE FIRE HOUSE & 12 \\
\hline SITE 300 & OS899D & RIFLE RANGE & 41 \\
\hline SITE 300 & OSM1 & MAGAZINE-STORAGE VAULT & 49 \\
\hline SITE 300 & OSM10 & HE STORAGE MAGAZINE & 9 \\
\hline SITE 300 & OSM15 & HE STORAGE MAGAZINE & 9 \\
\hline SITE 300 & OSM2 & HE WASTE STORAGE MAGAZINE & 55 \\
\hline SITE 300 & OSM21 & MAGAZINE-STORAGE VAULT & 56 \\
\hline SITE 300 & OSM22 & MAGAZINE-STORAGE VAULT & 56 \\
\hline SITE 300 & OSM23 & MAGAZINE - STORAGE VAULT & 56 \\
\hline SITE 300 & OSM24 & MAGAZINE-STORAGE VAULT & 52 \\
\hline SITE 300 & OSM3 & HE WASTE STORAGE MAGAZINE & 55 \\
\hline SITE 300 & OSM30 & MAGAZINE-STORAGE VAULT & 55 \\
\hline SITE 300 & OSM31 & MAGAZINE-STORAGE VAULT & 55 \\
\hline SITE 300 & OSM32 & MAGAZINE-STORAGE VAULT & 55 \\
\hline SITE 300 & OSM33 & HE STORAGE MAGAZINE & 52 \\
\hline SITE 300 & OSM34 & MAGAZINE-HE CUBCL STRGE & 52 \\
\hline SITE 300 & OSM35 & MAGAZINE-STORAGE VAULT & 49 \\
\hline SITE 300 & OSM36 & HE STORAGE MAGAZINE & 49 \\
\hline SITE 300 & OSM37 & MAGAZINE-HE CUBCL STRGE & 47 \\
\hline SITE 300 & OSM38 & MAGAZINE-STORAGE VAULT & 14 \\
\hline SITE 300 & OSM4 & HE WASTE STORAGE MAGAZINE & 55 \\
\hline SITE 300 & OSM41 & MAGAZINE-STORAGE VAULT & 14 \\
\hline SITE 300 & OSM5 & HE WASTE STORAGE MAGAZINE & 52 \\
\hline SITE 300 & OSM51 & HE STORAGE MAGAZINE & 52 \\
\hline SITE 300 & OSM52 & MAGAZINE-STORAGE VAULT & 28 \\
\hline SITE 300 & OSM58 & STORAGE MAGAZINE & 51 \\
\hline SITE 300 & OSM7 & MAGAZINE-STORAGE VAULT & 55 \\
\hline SITE 300 & OSM70 & MAGAZINE-STORAGE VAULT & 55 \\
\hline SITE 300 & OSM71 & MAGAZINE-STORAGE VAULT & 52 \\
\hline SITE 300 & OSM72 & MAGAZINE-STORAGE VAULT & 52 \\
\hline SITE 300 & OSM8 & MAGAZINE-STORAGE VAULT & 55 \\
\hline SITE 300 & OSM80 & M80 READY VAULT & 54 \\
\hline SITE 300 & OSM817C & HE STORAGE MAGAZINE & 54 \\
\hline SITE 300 & OSM82 & MAGAZINE - STORAGE & 52 \\
\hline SITE 300 & OSM83 & M83 READY VAULT & 57 \\
\hline SITE 300 & OSM832B & EXPLOSIVES STORAGE & 54 \\
\hline SITE 300 & OSM832D & HE SHIPPING AND RECEIVING & 54 \\
\hline
\end{tabular}




\begin{tabular}{|c|c|c|c|}
\hline SITE 300 & OSM834M & HE STORAGE & 28 \\
\hline SITE 300 & OSM854H & MAGAZINE STORAGE & 50 \\
\hline SITE 300 & OSM854V & STORAGE & 28 \\
\hline SITE 300 & OSM857 & MAGAZINE STORAGE VAULT & 26 \\
\hline SITE 300 & OSV822AD & CONTRL MTLS-STRG VAULT & 45 \\
\hline MAIN SITE & U011 & ERD TREATMNT FAC A & 23 \\
\hline MAIN SITE & U042 & ERD TREATMNT FAC B & 22 \\
\hline MAIN SITE & U119 & TELCOM NODE \#11 & 69 \\
\hline MAIN SITE & U172 & TELCOM NODE \#12 & 24 \\
\hline MAIN SITE & U187 & ERD TREATMNT FAC & 18 \\
\hline MAIN SITE & U193 & SEWER DIVERSION FAC & 21 \\
\hline MAIN SITE & U271T & MICROWAVE TOWER & 23 \\
\hline MAIN SITE & U283 & TELCOM NODE \#3 & 24 \\
\hline MAIN SITE & U291 & LCW STATION & 41 \\
\hline MAIN SITE & U295 & PUMP HOUSE & 48 \\
\hline MAIN SITE & U299 & TELCOM NODE \#4 & 24 \\
\hline MAIN SITE & U313A & TELCOM NODE \#10 & 24 \\
\hline MAIN SITE & U313B & HC EMRGCY COMM RADIO CTR & 20 \\
\hline MAIN SITE & U325 & LCW CONTROL & 52 \\
\hline MAIN SITE & U328C & PE/LCW CONTROL BLDG & 35 \\
\hline MAIN SITE & U416 & BOILER FACILITY & 26 \\
\hline MAIN SITE & U424 & ELECTRICAL SUBSTATION & 58 \\
\hline MAIN SITE & U430 & TELCOM NODE \#9 & 24 \\
\hline MAIN SITE & U448 & TELCOM NODE \#8 & 24 \\
\hline MAIN SITE & U470 & TELCOM NODE \#2 & 24 \\
\hline MAIN SITE & U472 & ERD TREATMENT FAC D & 17 \\
\hline MAIN SITE & U599 & TELCOM NODES $5 \& 6$ & 24 \\
\hline MAIN SITE & U6042 & MOCHO POT PUMP STA HH & 58 \\
\hline MAIN SITE & U6047 & SANDIA WTR TNKS CNTRL STATN & 52 \\
\hline MAIN SITE & U664 & TELCOM NODE \#7 & 24 \\
\hline SITE 300 & U815 & CNTRL AIR PLANT/STRG & 54 \\
\hline SITE 300 & U842 & INSTAL COMM HUT\#1 & 24 \\
\hline SITE 300 & U844 & CW BOOSTER STATION \#1 & 52 \\
\hline SITE 300 & U846 & ELECTRICAL SUBSTATION & 52 \\
\hline SITE 300 & U847 & CW BOOSTER STATION \#2 & 52 \\
\hline SITE 300 & U849 & COMM RADIO TRANS & 52 \\
\hline SITE 300 & U849A & COMM RADIO TWR CNTRL BLDG & 24 \\
\hline SITE 300 & U849B & COMM TWR GENERATOR BLDG & 51 \\
\hline
\end{tabular}


Five-Year NRHP Re-Evaluation of

\begin{tabular}{|l|l|l|r|r|}
\hline SITE 300 & U849C & COMM RADIO TWR CNTRL BLDG & 9 & \\
\hline SITE 300 & U853 & CW BOOSTER STATION \#3 & 52 & \\
\hline SITE 300 & U865D & ELECTRICAL SUBSTATION & 29 & \\
\hline SITE 300 & U866 & INSTAL COMM HUT \#2 & 24 & \\
\hline SITE 300 & U882T & S300 MICROWAVE TOWER & 23 & \\
\hline SITE 300 & U887 & WELL 20 POTBL WATER WELL & 21 & \\
\hline SITE 300 & U888 & WELL 18 POTBL WATER WELL & 32 & \\
\hline
\end{tabular}




\section{Appendix II. LLNL Properties Turning 50 since 2005 Report}

\begin{tabular}{|c|c|c|c|c|}
\hline Site & Asset ID & Facility Name & $\begin{array}{l}\text { Facility } \\
\text { Age }\end{array}$ & $\begin{array}{l}\text { Gross } \\
\text { Sq Ft }\end{array}$ \\
\hline MAIN SITE & 116 & G.S & 53 & 7,781 \\
\hline MAIN SITE & 121 & PLS OFFICE & 56 & 90,759 \\
\hline MAIN SITE & 123 & AUDITORIUM & 53 & 7,742 \\
\hline MAIN SITE & 125 & WEST CAFETERIA & 52 & 12,513 \\
\hline MAIN SITE & 131 & ENGINEERING & 52 & 285,308 \\
\hline SITE 300 & 15WST & WATER STORAGE TANKS - 11 & 52 & \\
\hline MAIN SITE & 162 & RESEARCH/CRYSTAL GTH & 51 & 19,042 \\
\hline MAIN SITE & 165 & OPTICS/DEVELOPMENT LAB & 53 & 10,053 \\
\hline MAIN SITE & 166 & DEVELOPMENT LAB & 51 & 13,226 \\
\hline MAIN SITE & 173 & PLS WELD SHOP & 54 & 413 \\
\hline MAIN SITE & 174 & PLS & 54 & 19,437 \\
\hline MAIN SITE & 176 & PLS SHOP & 54 & 3,973 \\
\hline MAIN SITE & 194 & PLS & 53 & 41,543 \\
\hline MAIN SITE & 233 & MATERIALS MANAGEMENT & 51 & 4,933 \\
\hline MAIN SITE & 241 & VACANT & 51 & 54,369 \\
\hline MAIN SITE & 243 & VACANT & 52 & 20,000 \\
\hline MAIN SITE & 251 & VACANT & 55 & 31,128 \\
\hline MAIN SITE & 253 & HC DEPT OFFICES \& LABS & 52 & 30,932 \\
\hline MAIN SITE & 254 & HC BIO ASSAY LAB & 51 & 2,488 \\
\hline MAIN SITE & 262 & G.S & 53 & 10,882 \\
\hline MAIN SITE & 280 & VACANT & 55 & 5,469 \\
\hline MAIN SITE & 281 & LABORATORY & 55 & 18,505 \\
\hline MAIN SITE & 312 & IMF MANAGED FACILITY & 55 & 11,482 \\
\hline MAIN SITE & $321 \mathrm{~A}$ & MATERIALS FAB SHOP & 56 & 59,515 \\
\hline MAIN SITE & 321B & MATERIALS FAB SHOP & 56 & 7,511 \\
\hline MAIN SITE & $321 C$ & MATERIALS FAB SHOP & 56 & 78,335 \\
\hline MAIN SITE & $321 \mathrm{D}$ & EE FABRICATION & 56 & 2,106 \\
\hline MAIN SITE & $321 \mathrm{E}$ & MMED BOILER ROOM & 56 & 2,581 \\
\hline MAIN SITE & 323 & EMERGENCY SERVICES / FIRE STATION\#1 & 52 & 18,555 \\
\hline MAIN SITE & 324 & EMERGENCY SERVICES / ALARMS OFFICE & 52 & 10,181 \\
\hline MAIN SITE & 327 & RADIOGRAPHY & 52 & 19,100 \\
\hline MAIN SITE & 331 & TRITIUM FACILITY & 52 & 30,484 \\
\hline MAIN SITE & 332 & PU FACILITY & 51 & 104,787 \\
\hline
\end{tabular}


Five-Year NRHP Re-Evaluation of Historic Building Assessment November 2011 LLNL - Main Site and Site 300

\begin{tabular}{|c|c|c|c|c|}
\hline MAIN SITE & 343 & IMF MANAGED OFFICE/LAB FACILITY & 51 & 27,368 \\
\hline MAIN SITE & 411 & SHIPPING/RECEIVING & 55 & 71,625 \\
\hline MAIN SITE & 418 & MUSD PAINT SHOP & 53 & 12,167 \\
\hline MAIN SITE & 435 & VACANT & 51 & 57,724 \\
\hline MAIN SITE & 436 & PLS SHIPPING/RECEIVING/STORAGE & 55 & 9,745 \\
\hline MAIN SITE & 443 & VACANT & 50 & 8,953 \\
\hline MAIN SITE & 444 & VACANT & 55 & 805 \\
\hline MAIN SITE & 446 & VACANT & 51 & 1,743 \\
\hline MAIN SITE & $519 \mathrm{~A}$ & HEAVY EQUIPMENT STORAGE & 55 & 594 \\
\hline SITE 300 & $802 \mathrm{~A}$ & VACANT & 56 & 3,264 \\
\hline SITE 300 & 803 & EPD/ORAD STRG WRHS & 54 & 1,719 \\
\hline SITE 300 & 804 & STAGING AREA & 53 & 107 \\
\hline SITE 300 & 805 & INERT MACHNG/EXPLVS WST PACKNG & 54 & 6,830 \\
\hline SITE 300 & $806 \mathrm{~A}$ & HE MACHINING & 54 & 3,417 \\
\hline SITE 300 & $806 \mathrm{~B}$ & HE MACHINING & 54 & 4,088 \\
\hline SITE 300 & $806 C$ & MACHINING STORAGE & 54 & 640 \\
\hline SITE 300 & $806 \mathrm{D}$ & MACHINING STORAGE & 52 & 192 \\
\hline SITE 300 & 807 & HE MACHINING & 51 & 1,575 \\
\hline SITE 300 & $809 \mathrm{~A}$ & HE PRESSING & 52 & 2,570 \\
\hline SITE 300 & 811 & VACANT & 52 & 1,081 \\
\hline SITE 300 & $812 \mathrm{~A}$ & VACANT & 51 & 2,656 \\
\hline SITE 300 & 813 & CHANGE HOUSE & 54 & 2,870 \\
\hline SITE 300 & $817 \mathrm{~A}$ & HE PRESSING CONTROL ROOM & 54 & 417 \\
\hline SITE 300 & $817 \mathrm{~B}$ & HE PRESSING CELL & 54 & 639 \\
\hline SITE 300 & 817D & HE PRESSING STORAGE & 54 & 207 \\
\hline SITE 300 & $817 \mathrm{~F}$ & HE PRESSING OVENS & 54 & 526 \\
\hline SITE 300 & $817 G$ & HE PRESSING BOILERS & 54 & 237 \\
\hline SITE 300 & $817 \mathrm{H}$ & HE PRESSING INERT STORAGE & 54 & 890 \\
\hline SITE 300 & 819 & PE/STORAGE-C\&M SHOPS & 50 & 828 \\
\hline SITE 300 & 821 & CHEMISTRY STORAGE & 50 & 650 \\
\hline SITE 300 & 825 & CHEM PROCESS FACILITY & 52 & 1,370 \\
\hline SITE 300 & 826 & CHEM PROCESS FACILITY & 50 & 1,638 \\
\hline SITE 300 & 830 & VACANT & 54 & 1,764 \\
\hline SITE 300 & $832 \mathrm{~A}$ & STORAGE & 54 & 540 \\
\hline SITE 300 & $832 \mathrm{C}$ & STORAGE & 54 & 335 \\
\hline SITE 300 & 833 & EPD/ERD SERVICE-R\&D & 52 & 1,892 \\
\hline SITE 300 & 8340 & EPD/ERD SRVC-MNTRNG TF834 & 50 & 282 \\
\hline SITE 300 & $834 \mathrm{~A}$ & THERMAL TEST FACILITY & 51 & 1,694 \\
\hline
\end{tabular}


Five-Year NRHP Re-Evaluation of Historic Building Assessment

\begin{tabular}{|c|c|c|c|c|}
\hline SITE 300 & 834B & VACANT & 51 & 751 \\
\hline SITE 300 & $834 C$ & VACANT & 51 & 751 \\
\hline SITE 300 & 834D & VACANT & 51 & 1,694 \\
\hline SITE 300 & $834 \mathrm{E}$ & VACANT & 51 & 998 \\
\hline SITE 300 & $834 \mathrm{~F}$ & VACANT & 51 & 649 \\
\hline SITE 300 & $834 G$ & VACANT & 51 & 527 \\
\hline SITE 300 & $834 \mathrm{H}$ & THERMAL TEST FACILITY & 51 & 998 \\
\hline SITE 300 & $834 \mathrm{~K}$ & PUMP STATION & 50 & 545 \\
\hline SITE 300 & 835 & EPD/ERD STORAGE & 50 & 1,216 \\
\hline SITE 300 & 841 & PE/STORAGE - C\&M SHOPS & 52 & 1,786 \\
\hline SITE 300 & $845 A$ & EXPL WASTE TREATMNT FAC & 56 & 431 \\
\hline SITE 300 & 850 & VACANT & 51 & 5,095 \\
\hline SITE 300 & $851 \mathrm{~A}$ & FIRING FACILITY & 51 & 12,996 \\
\hline SITE 300 & $851 \mathrm{~B}$ & MACHINE SHOP & 51 & 985 \\
\hline SITE 300 & $854 \mathrm{~A}$ & VACANT & 52 & 2,458 \\
\hline SITE 300 & $855 \mathrm{~A}$ & HE MACHINING & 52 & 667 \\
\hline SITE 300 & $855 B$ & HE MACHINING & 52 & 637 \\
\hline SITE 300 & $855 C$ & HE MACHINING & 50 & 612 \\
\hline SITE 300 & 856 & VACANT & 51 & 1,613 \\
\hline SITE 300 & 859 & STORAGE & 52 & 1,500 \\
\hline SITE 300 & 870 & OFFICE FACILITY & 53 & 4,000 \\
\hline SITE 300 & 871 & ADMINISTRATION & 53 & 7,928 \\
\hline SITE 300 & 872 & PE/PAINT SHOP & 56 & 1,887 \\
\hline SITE 300 & 873 & $\mathrm{PE} / \mathrm{C} \& \mathrm{M}$ SHOPS & 53 & 17,452 \\
\hline SITE 300 & 874 & MECHANICAL SHOPS & 52 & 19,972 \\
\hline SITE 300 & 875 & PE/SUPPLY \& MAINTENANCE & 51 & 15,171 \\
\hline SITE 300 & 876 & STORES \& RECLAMATION & 51 & 2,400 \\
\hline SITE 300 & 877 & COMPUTER TECHL SUPPORT & 50 & 3,352 \\
\hline SITE 300 & 895 & EPD/ORAD OFFICE & 51 & 380 \\
\hline MAIN SITE & OS518 & GAS CYLINDER DOCK & 52 & \\
\hline SITE 300 & OS812B & VACANT & 55 & \\
\hline SITE 300 & OS812C & VACANT & 55 & \\
\hline SITE 300 & OS858B & DROP TOWER - VACANT & 51 & \\
\hline SITE 300 & OS897 & WEST CONTROL POST & 52 & \\
\hline SITE 300 & OS898 & WEST OBSERVATION POST & 52 & \\
\hline SITE 300 & OSM2 & HE WASTE STORAGE MAGAZINE & 55 & \\
\hline SITE 300 & OSM21 & MAGAZINE-STORAGE VAULT & 56 & \\
\hline SITE 300 & OSM22 & MAGAZINE-STORAGE VAULT & 56 & \\
\hline
\end{tabular}




\begin{tabular}{|c|c|c|c|}
\hline SITE 300 & OSM23 & MAGAZINE - STORAGE VAULT & 56 \\
\hline SITE 300 & OSM24 & MAGAZINE-STORAGE VAULT & 52 \\
\hline SITE 300 & OSM3 & HE WASTE STORAGE MAGAZINE & 55 \\
\hline SITE 300 & OSM30 & MAGAZINE-STORAGE VAULT & 55 \\
\hline SITE 300 & OSM31 & MAGAZINE-STORAGE VAULT & 55 \\
\hline SITE 300 & OSM32 & MAGAZINE-STORAGE VAULT & 55 \\
\hline SITE 300 & OSM33 & HE STORAGE MAGAZINE & 52 \\
\hline SITE 300 & OSM34 & MAGAZINE-HE CUBCL STRGE & 52 \\
\hline SITE 300 & OSM4 & HE WASTE STORAGE MAGAZINE & 55 \\
\hline SITE 300 & OSM5 & HE WASTE STORAGE MAGAZINE & 52 \\
\hline SITE 300 & OSM51 & HE STORAGE MAGAZINE & 52 \\
\hline SITE 300 & OSM58 & STORAGE MAGAZINE & 51 \\
\hline SITE 300 & OSM7 & MAGAZINE-STORAGE VAULT & 55 \\
\hline SITE 300 & OSM70 & MAGAZINE-STORAGE VAULT & 55 \\
\hline SITE 300 & OSM71 & MAGAZINE-STORAGE VAULT & 52 \\
\hline SITE 300 & OSM72 & MAGAZINE-STORAGE VAULT & 52 \\
\hline SITE 300 & OSM8 & MAGAZINE-STORAGE VAULT & 55 \\
\hline SITE 300 & OSM80 & M80 READY VAULT & 54 \\
\hline SITE 300 & OSM817C & HE STORAGE MAGAZINE & 54 \\
\hline SITE 300 & OSM82 & MAGAZINE - STORAGE & 52 \\
\hline SITE 300 & OSM832B & EXPLOSIVES STORAGE & 54 \\
\hline SITE 300 & OSM832D & HE SHIPPING AND RECEIVING & 54 \\
\hline SITE 300 & OSM854H & MAGAZINE STORAGE & 50 \\
\hline MAIN SITE & U325 & LCW CONTROL & 52 \\
\hline MAIN SITE & U6047 & SANDIA WTR TNKS CNTRL STATN & 52 \\
\hline SITE 300 & U815 & CNTRL AIR PLANT/STRG & 54 \\
\hline SITE 300 & U844 & CW BOOSTER STATION \#1 & 52 \\
\hline SITE 300 & U846 & ELECTRICAL SUBSTATION & 52 \\
\hline SITE 300 & U847 & CW BOOSTER STATION \#2 & 52 \\
\hline SITE 300 & U849 & COMM RADIO TRANS & 52 \\
\hline SITE 300 & U849B & COMM TWR GENERATOR BLDG & 51 \\
\hline SITE 300 & U853 & CW BOOSTER STATION \#3 & 52 \\
\hline
\end{tabular}




\section{Appendix III. Site 300 Building 810 Complex Assessment}

\section{DESCRIPTION}

The Building 810 complex is part of the original Site 300 Process Area constructed between 1957 and 1968 and located in the southern part of LLNL's Site 300. The 2005 site survey and historic building assessment recommended that the Process Area and Chemistry Area be considered a non-contiguous historic district encompassing Building 805, 806A, 806B, 807, 817A, 817B, 817F, 825, 826, 827A, and 827C. Buildings 810A, 810B, and 810C were inadvertently omitted from the assessment and recommendation at that time. This assessment intends to rectify that oversight and make a recommendation regarding the Building 810 complex.

The Building 810 complex consists of three buildings, Building 810A (Figure 21), Building 810B (Figure 22), and Building 810C (Figure 23). Completed in 1959, Building 810A was originally designated as Building 810 ; it became Building $810 \mathrm{~A}$ when $810 \mathrm{~B}$ and $810 \mathrm{C}$ were built in 1982.

Building $810 \mathrm{~A}$ is two structures on a shared concrete slab foundation. The northern, two-story structure contains three assembly bays or cells while the smaller, one-story, southern structure houses support activities (an office, utility room, restroom, and shop). The roof of the smaller, southern structure extends to the front of the taller, northern structure, forming a roof over the walkway between the two building elements and connecting them as one building. Buildings $810 \mathrm{~A}$ and $810 \mathrm{~B}$ are steel-framed, concrete buildings. $810 \mathrm{~A}$ 's roof is frangible above the assembly bays. $810 \mathrm{C}$ is concrete block with a concrete roof that slants down from north to south. 
Five-Year NRHP Re-Evaluation of Historic Building Assessment

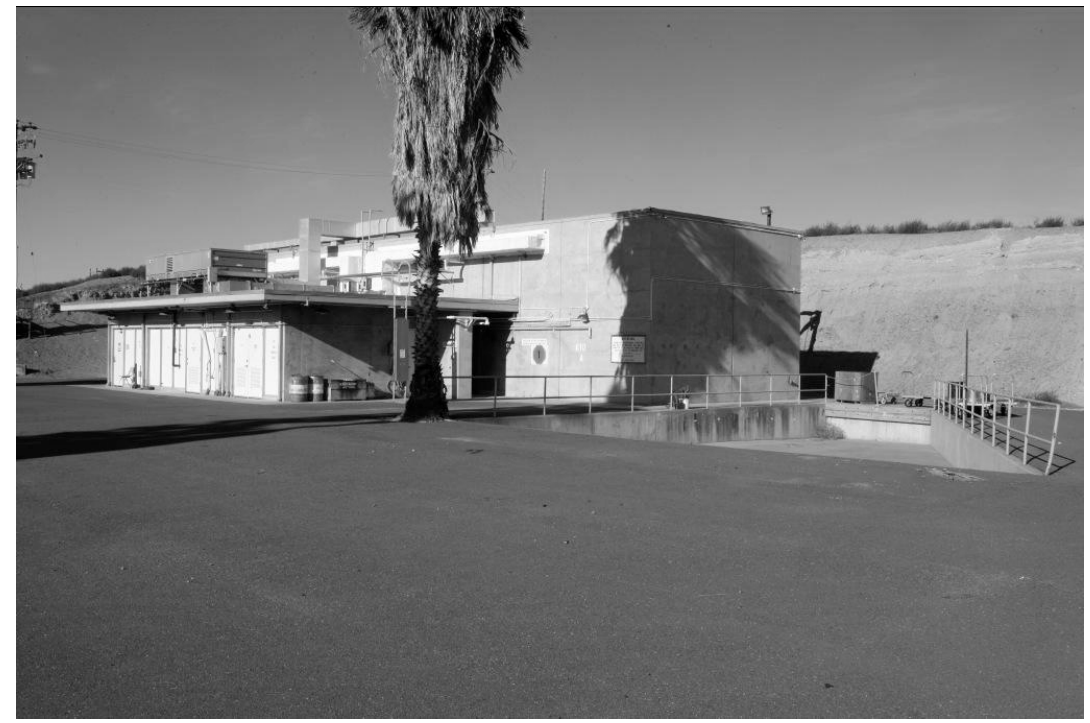

Figure 20. Building 810A, south (front) and east sides, showing both structures, 2010

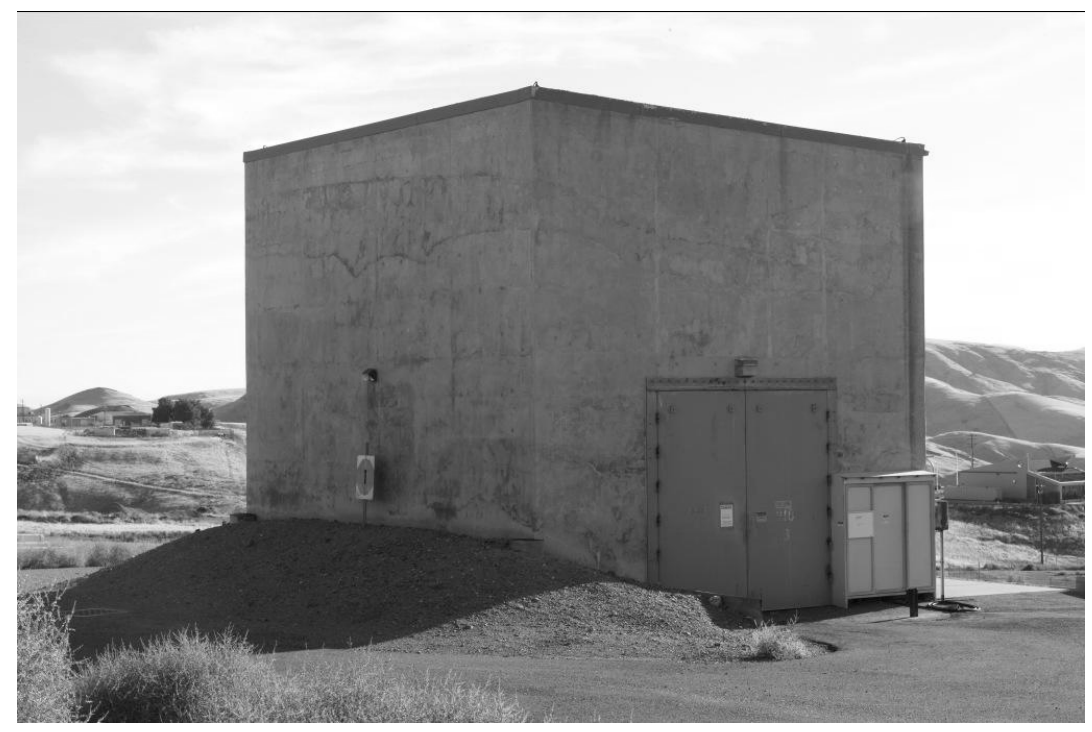

Figure 21. Building 810B, south and east sides, 2010 


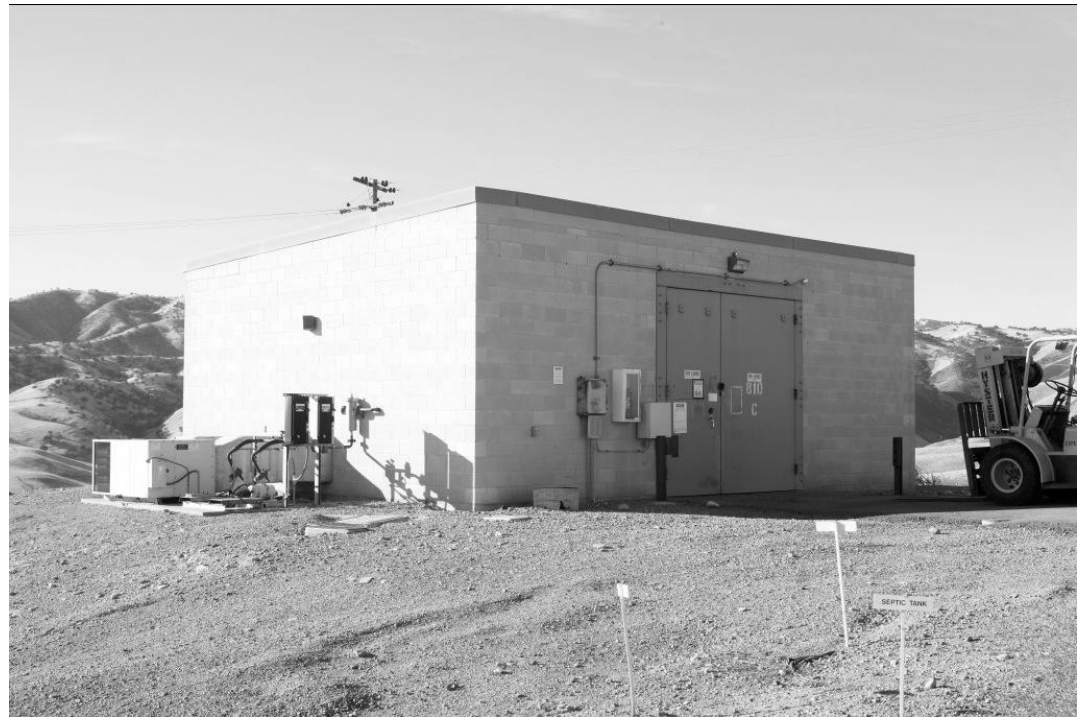

Figure 22. Building 810C, north side, 2010

\section{MISSION HISTORY}

In 1955, LLNL obtained the initial piece of land that formed Site 300. It later purchased additional land; Site 300 is currently 7,000 acres. One of the earliest functions moved to the site was the High Explosive (HE) Process Area, which had the focused as signment of developing and fabricating HE for LLNL's nuclear weapons designs. The HE Process Area started in 1957 with a few buildings (Building 805 and the Building 806 Complex), but expanded over the succeeding decade, placing individual elements of the process into specific complexes or buildings.

Building 810 , completed in 1959 , housed assembly activities. It retained that mission throughout its history. When Buildings 810B and 810C were built in 1982, they served as an additional assembly building and staging facility, respectively. While Building 810 was renamed Building $810 \mathrm{~A}$, its mission did not change.

\section{CONSTRUCTION HISTORY}

Rogers Engineering Co., Inc., of San Francisco completed drawings for Building 810 in 1958 as part of the Phase III construction site plan for the Process Area. They completed construction on the two structures in $1959 .{ }^{8}$

\footnotetext{
8 “Site Plan, Bldg's 304, 304B, 304C, 307, 308, 310, 316, 324 \& 325, Process Area, Site Plan," 1958, PS257-810002 JA, LLNL Plant Engineering Library.
} 
The main (north) section of Building 810 houses a repair room, a high explosives storage vault, and three assembly cells with double steel doors providing entry to each cell on the north side (Figure 23). The south side of the cells show ventilation louvers and insulated cement asbestos panels. A concrete loading dock slopes down from the walkway on the east end of the structure. ${ }^{9}$

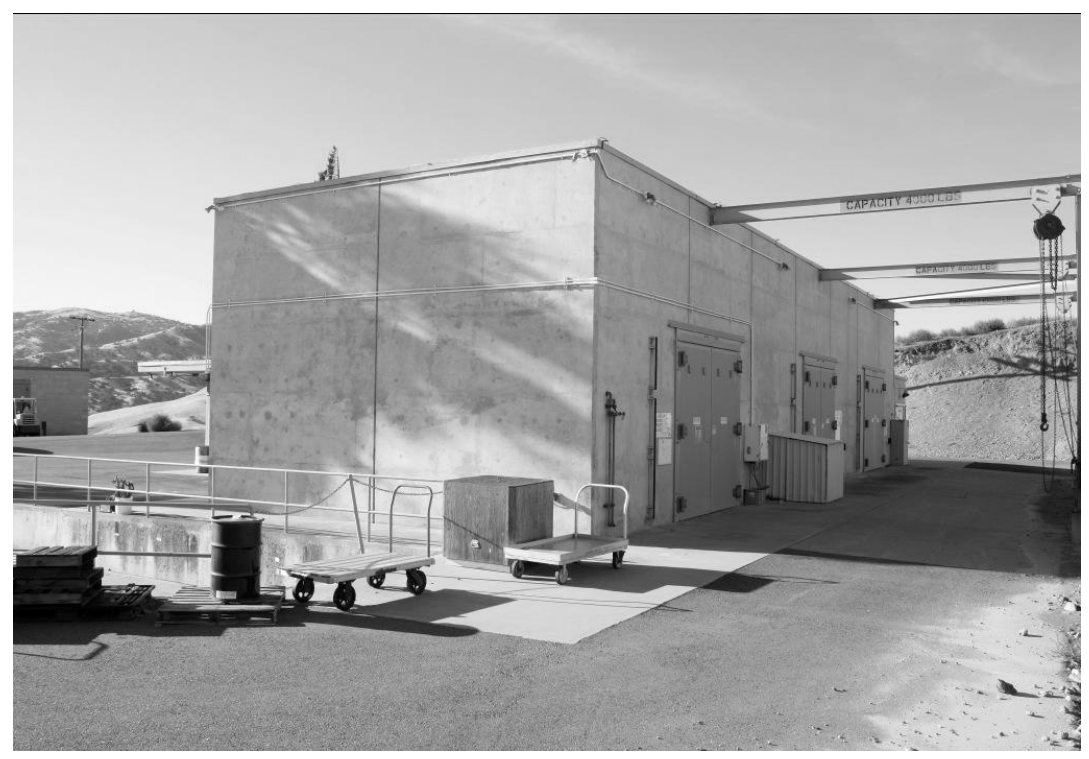

Figure 23. North side of Building 810A, showing assembly cell doors, 2010

The south structure of Building $810 \mathrm{~A}$ is also concrete. The concrete roof overhang forms a ceiling for the passageway between the two structures. This portion of the building originally housed an adhesive preparation room, an office, a utility room, a restroom, and inert storage.

LLNL's Plant Engineering redesigned the office area in 1974, removing the wall between the original office and the adhesive preparation room and relocating the equip ment from the latter to the repair room in the building's north section. ${ }^{10}$

In 1982, two additional buildings were located at the Building 810 site. Building $810 \mathrm{~B}$ served as a fourth assembly bay. The steel-framed, poured concrete building houses a single room, with concrete beams and ceiling on a concrete floor slab. It has a built-up roof over insulation over concrete. The interior houses an assembly pit and a bridge crane. ${ }^{11}$ The building has undergone no renovations since its original construction.

\footnotetext{
9 “Architectural Plan, Section, Elevations \& Details, Building 310, Process Area,” 1958, PS247-810-003JA, LLNL Plant Engineering Library.

10 “Bldg. 810 Office Expansion,” 1974, PSA-74-810-001C, LLNL Plant Engineering Library.

11 "Site 300 Assembly Bay No. 4, Bldg. 810B, Plans, Section Elevations and Details," 1982, PSA82-810-202D, LLNL Plant Engineering Library.
} 
Building $810 \mathrm{C}$ is a staging facility, providing temporary storage for items in transit. Like the other Process Area facilities, the building is concrete, in this case 8-inch concrete block for the walls. It rests on a finished concrete slab and has two-leaf metal service doors. The built-up insulated roof with metal fascia rests on pre-cast concrete planks and slants down from north to south. ${ }^{12}$ The building has undergone no renovations since its original construction.

\section{INTEGRITY}

All three buildings in the Building 810 Complex retain integrity for the HE Process Area's period of significance. The only change to their design was the expansion of the office area in Building $810 \mathrm{~A}$ in 1974 . This was a minor change to the interior layout and did not have a negative impact on the building's design or materials. The building retains integrity.

\section{RECOMMENDATION}

This report recommends that Building $810 \mathrm{~A}$ be considered a contributing element to the LLNL Process Area and Chemistry Area Historic District, the period of significance of which is 19571991. The 2005 assessment considered the Process Area and Chemistry Area eligible for National Register consideration under Criterion A, association with a historic event or pattern of events. The Process Area and Chemistry Area's specific contributions were to LLNL's HE work in nuclear weapons design during the Cold War.

Buildings $810 \mathrm{~B}$ and $810 \mathrm{C}$ do not appear to be contributing elements to the Process Area and Chemistry Area Historic District. Built in 1982, they contributed little to LLNL's overall Cold War high explosive development and fabrication efforts. While they retain integrity for their original period of construction, they are too young to be part of the district.

As with the other elements of the HE Process Area Historic District, Building 810A housed a distinct and essential function within the overall high explosive development process. The overall HE process activities contributed to LLNL's Cold War activities; the assembly activities housed in Building 810A were part of that overall process.

Building 810A retains integrity for the period of significance and should be added to the set of buildings forming the Process Area and Chemistry Area Historic District.

\footnotetext{
12 "Site 300 Staging Facility, Bldg. 810, Plans, Sections, Elevations and Details," 1982, PSA82-810-301D, LLNL
} Plant Engineering Library. 


\section{Appendix IV. Acronyms}

\begin{tabular}{|c|c|}
\hline AMS & accelerator mass spectrometry \\
\hline $\mathrm{ASC}$ & Accelerated Strategic Computing \\
\hline ASCI & Accelerated Strategic Computing Initiative \\
\hline ATA & Advanced Test Accelerator \\
\hline CAMS & Center for Accelerator Mass Spectrometry \\
\hline DHS & Department of Homeland Security \\
\hline DOE & U.S. Department of Energy \\
\hline Draft PA & Draft Programmatic Agreement \\
\hline GOCO & Government-Owned, Contractor-Operated \\
\hline $\mathrm{HE}$ & high explosive(s) \\
\hline ICF & inertial confinement fusion \\
\hline LIFE & Laser Inertial Fusion Engine \\
\hline LLNL & Lawrence Livermore National Laboratory \\
\hline LLNS & Lawrence Livermore National Security, LLC \\
\hline LPTR & Livermore Pool-Type Reactor \\
\hline LSO & Livermore Site Office \\
\hline NAI & Nonproliferation, Arms Control, and International Security Directorate \\
\hline NAS & Naval Air Station \\
\hline NIF & National Ignition Facility \\
\hline NNSA & National Nuclear Security Administration \\
\hline NRHP & National Register of Historic Places \\
\hline
\end{tabular}


Five-Year NRHP Re-Evaluation of

SHPO State Historic Preservation Officer

SSP Stockpile Stewardship Program 